\title{
CONSERVAÇÃO DE COGUMELOS COMESTÍVEIS (Pleurotus sajor-caju) POR ACIDIFICAÇÃO E PROCESSAMENTO TÉRMICO E POR DESIDRATAÇÃO
}

\section{MARIANA SARTORI NARDIN}

\author{
Engenheira Agrônoma
}

Orientador: Prof. Dr. JOÃO NUNES NOGUEIRA

Dissertação apresentada à Escola Superior de Agricultura "Luiz de Queiroz", Universidade de São Paulo, para a obtenção do título de Mestre em Ciências, Área de Concentração: Ciência e Tecnologia de Alimentos.

P I RA CICA B A

Estado de São Paulo - Brasil

Janeiro - 1999 
Ficha catalográfica preparada pela Seção de Livros da Divisão de Biblioteca e Documentação - PCAP/USP

\section{Wehr, Tim Rudolf}

W414v Variações nas características da madeira de Eucalyptus grandis Hill ex Maiden e suas influências na qualidade de cavacos em cozimentos Kraft. Piracicaba, 1991.

84p. ilus.

\section{Diss.(Mestre) - ESALQ}

Bibliografia.

1. Cavaco - Qualidade 2. Celulose Kraft 3. Eucalipto Produto derivado 4. Madeira de eucalipto I. Escola Superior de Agricultura Luiz de Queiroz, Piracicaba 
Agradeço a Deus, pela minha vida!!

Dedico a toda minha família, especialmente ao Luiz Fernando, aos meus pais Celeste e Ermelindo, e aos meus irmãos Tetê e Tutti, com muito amor. 


\section{AGRADECIMENTOS}

À DEUS, pela vitória de mais esta conquista.

A todos aqueles que de alguma forma contribuíram para a realização deste trabalho, especialmente:

- Ao Prof. Dr. João Nunes Nogueira, pela orientação, apoio e colaboração;

- À todos os professores que contribuíram para minha formação acadêmica, pelos preciosos ensinamentos;

- À Fundação de Coordenação de Aperfeiçoamento de Pessoal de Nível Superior (CAPES), pela concessão da bolsa de estudos;

- Aos professores Cláudio Rosa Gallo, Jorge Horii, Luiz Gonzaga do Prado Filho, Marília Oetterer e Murilo Graner, pelas valiosas sugestões;

- Aos técnicos de laboratório Ivani Aparecida Marchetto Moreno e José Carlos Teixeira Mendes, pelo apoio na realização das análises laboratoriais;

- À equipe de análise sensorial, pela colaboração inestimável;

- Às bibliotecárias Beatriz Helena Giongo e Mídiam Gustinelli, pelos serviços e contribuições;

- À amiga Fabiana Mongeli Peneireiro, pela amizade e pela valiosa ajuda nas análises estatísticas;

- À amiga Rosana de O. Freguglia, pela amizade e inestimável apoio;

- Às secretárias Márcia Regina Severino, Sandra de Marchi Vello e Regina Lúcia de Mello Lourenço, pelos auxílios prestados durante o curso; e,

- Aos colegas e amigos, pelo companheirismo e incentivo. 


\section{SUMÁRIO}

Página

LISTA DE FIGURAS …................................................................. iv

LISTA DE TABELAS .................................................................... vii

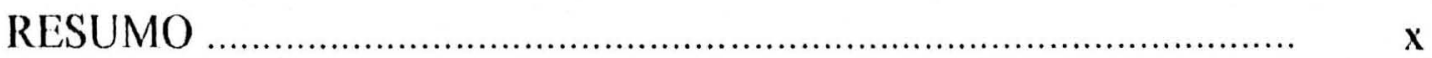

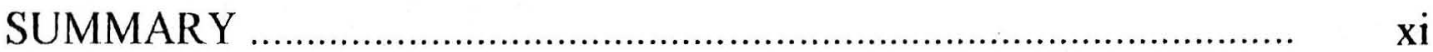

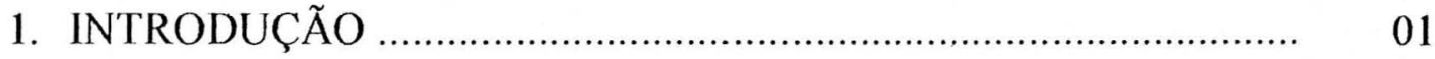

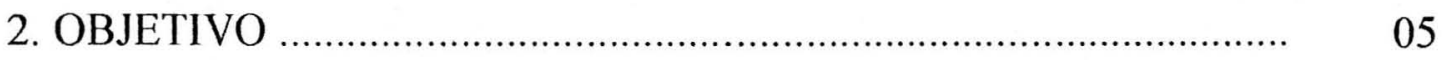

3. REVISÃO DE LITERATURA ….................................................... 06

3.1. Considerações gerais ................................................................ 06

3.2. Composição da matéria-prima .............................................. $\quad 10$

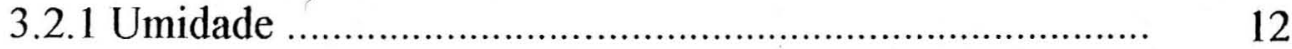

3.2.2. Carboidratos ......................................................... 12

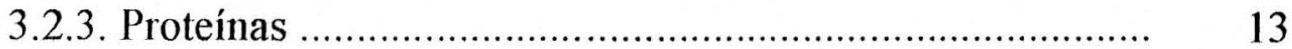

3.2.4. Lipídeos .................................................................... 15

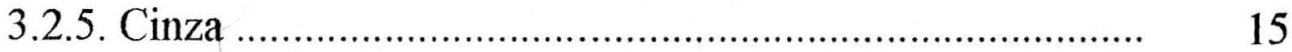

3.2.6. Vitaminas ……...................................................... 16

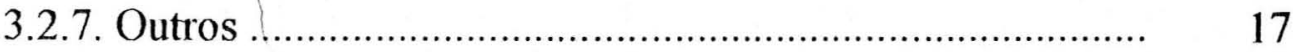

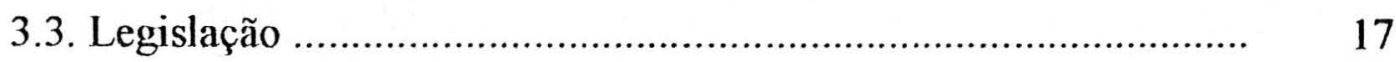

3.4. Fatores que afetam a qualidade dos cogumelos ......................... 20

3.4.1. Cor ............................................................................. 21

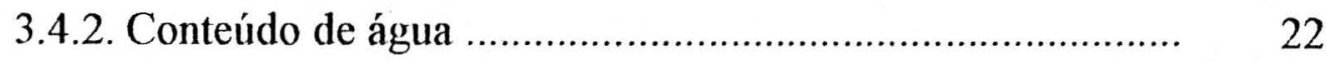


3.4.3. Desenvolvimento ........................................................ 22

3.5. Conservação de cogumelos frescos ........................................... 23

3.5.1. Refrigeração ............................................................... 23

3.5.2. Embalagem …....................................................... 24

3.5.3. Tratamento químico ......................................................... 25

3.6. Processamento …….................................................................. 25

3.6.1. Considerações gerais ...................................................... 25

3.6.2. Acidificação e processamento térmico ............................. 27

3.6.3. Aditivos ........................................................................ $\quad 32$

3.6.4. Desidratação ................................................................... 34

3.6.4.1. Secagem ...................................................... 35

3.6.4.2. Branqueamento e tratamento químico ................. 37

3.7. Tendências de consumo - Avaliação econômica ............................. 38

4. MATERIAL E MÉTODOS .......................................................... 42

4.1. Matéria-prima ….................................................................. 42

4.2. Caracterização da matéria-prima ............................................. 43

4.2.1. Análises fisicas .............................................................. 43

4.2.2. Análises químicas ........................................................ 43

4.3. Processamento ..................................................................... 44

4.3.1. Acidificação e processamento térmico ............................... 44

4.3.2. Desidratação .................................................................. 49

4.4. Avaliação do produto final ..................................................... 52

4.4.1. Acidificação e processamento térmico .............................. 52

4.4.1.1. Análises físicas .................................................. 53

4.4.1.2. Análises químicas ........................................... 54

4.4.1.3. Análise sensorial ................................................. 54

4.4.1.4. Análises microbiológicas .................................. 57 
4.4.2. Desidratação …............................................................. 57

4.4.2.1. Análises físicas .................................................... 58

4.4.2.2. Análises químicas .............................................. 58

4.4.2.3. Análise sensorial ................................................. 58

4.4.2.4. Análise estatística ................................................... 58

5. RESULTADOS E DISCUSSÃO ……............................................ 60

5.1. Caracterização da matéria-prima ............................................... 60

5.1.1. Análises fisicas ............................................................ 60

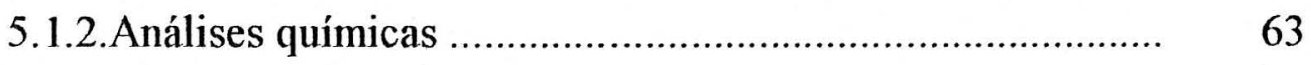

5.1.3. Curvas de acidificação ...................................................... 64

5.2. Caracterização do produto acidificado e processado termica-

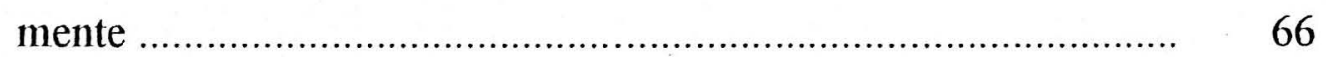

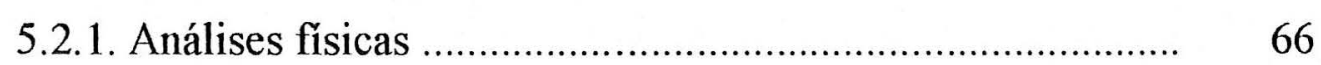

5.2.2. Análises químicas ....................................................... $\quad 74$

5.2.3. Análise sensorial ............................................................ 77

5.2.4. Análises microbiológicas ............................................. $\quad 83$

5.3. Caracterização do produto desidratado ...................................... 83

5.3.1. Curva de secagem ........................................................... 84

5.3.2. Análises físicas ................................................................ 85

5.3.3.Análises químicas ..................................................... $\quad 87$

5.3.4. Análise sensorial ............................................................. 89

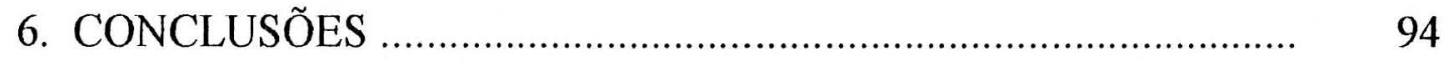

REFERÊNCIAS BIBLIOGRÁFICAS _............................................ 97 


\section{LISTA DE FIGURAS}

Página

1. Partes do cogumelo Pleurotus sp.

07

2. Pleurotus ostreatus, P.sajor-caju e P. sp. "Florida"

08

3. Fluxograma das operações utilizadas para obtenção de cogumelos acidificados e processados termicamente

4. Esquema dos tratamentos aplicados aos cogumelos para obtenção do produto em conserva

5. Fluxograma das operações utilizadas para obtenção de cogumelos desidratados

6. Esquema dos tratamentos de pré-secagem aplicados aos cogumelos ..

7. Modelo de ficha utilizado na avaliação sensorial das amostras do produto quanto à cor

8. Modelo de ficha utilizado na avaliação sensorial das amostras do produto quanto ao aroma, à textura e ao sabor

9. Curvas de acidificação de cogumelos da espécie Pleurotus sajorcaju, com cinco ácidos orgânicos, visando $\mathrm{pH} 4,3$ 
10. Efeito da adição de cálcio na textura de cogumelos processados termicamente

11. Valores médios de acidez titulável dos cogumelos processados termicamente, em função do tratamento

12. Valores médios das notas obtidas na avaliação sensorial, quanto à qualidade geral dos cogumelos processados termicamente

13. Valores médios das notas obtidas na avaliação sensorial, quanto à cor dos cogumelos processados termicamente

14. Valores médios das notas obtidas na avaliação sensorial, quanto à textura dos cogumelos processados termicamente

15. Valores médios das notas obtidas na avaliação sensorial, quanto ao sabor dos cogumelos processados termicamente

16. Valores médios das análises sensoriais das conservas de cogumelos, em função do tempo de armazenamento

17. Curva média de desidratação dos dados da razão de umidade em função dos diferentes tempos de desidratação, à temperatura de $70^{\circ} \mathrm{C}$

18. Valores médios das notas obtidas na avaliação sensorial, quanto à qualidade geral dos cogumelos desidratados 
19. Valores médios das notas obtidas na avaliação sensorial, quanto à cor dos cogumelos desidratados

20. Valores médios das notas obtidas na avaliação sensorial, quanto à textura dos cogumelos desidratados

21. Valores médios das notas obtidas na avaliação sensorial, quanto ao sabor dos cogumelos desidratados 


\section{LISTA DE TABELAS}

Página

1. Características físicas de amostras de cogumelos Pleurotus sajorcaju

2. Características químicas de amostras de cogumelos Pleurotus sajor-caju

3. Valores médios do peso bruto (g) dos recipientes dos cogumelos processados termicamente, em função do tempo de armazenamento

4. Valores médios do peso líquido (g) dos recipientes dos cogumelos processados termicamente, em função do tempo de armazenamento

5. Valores médios do peso drenado (g) dos recipientes dos cogumelos processados termicamente, em função do tempo de armazenamento

6. Valores médios do vácuo (pol. $\mathrm{Hg}$ ) dos recipientes dos cogumelos processados termicamente, em função do tempo de armazenamento 
7. Valores médios da textura (Lbf/g) dos cogumelos processados termicamente, em função do tempo de armazenamento

8. Valores médios de sólidos solúveis totais ( $\left.{ }^{\circ} \mathrm{Brix}\right)$ dos cogumelos processados termicamente, em função do tempo de armazenamento

9. Valores médios de $\mathrm{pH}$ dos cogumelos processados termicamente, em função do tempo de armazenamento

10. Valores médios de acidez total titulável (g ácido cítrico/100g) dos cogumelos processados termicamente, em função do tempo de armazenamento

11. Valores médios das análises sensoriais dos cogumelos acidificados e processados termicamente, em função dos tratamentos

12. Valores médios das análises sensoriais dos cogumelos acidificados e processados termicamente, em função do tempo de armazenamento

13. Valores médios do peso bruto ( $\mathrm{g}$ ) dos recipientes dos cogumelos desidratados 
14. Valores médios do peso líquido $(\mathrm{g})$ dos recipientes dos cogumelos desidratados

15. Valores médios da textura $(\mathrm{Lbf} / \mathrm{g})$ dos cogumelos desidratados .....

16. Valores médios de $\mathrm{pH}$ dos cogumelos desidratados

17. Valores médios de sólidos solúveis ( ${ }^{\circ}$ Brix) dos cogumelos desidratados

18. Valores médios das análises sensoriais dos cogumelos desidratados, em função dos tratamentos 


\title{
CONSERVAÇÃO DE COGUMELOS COMESTÍVEIS (Pleurotus sajor-caju) POR ACIDIFICAÇÃo E PROCESSAMENTO TÉRMICO E POR DESIDRATAÇÃo
}

\author{
Autora : Mariana Sartori Nardin \\ Orientador : Prof. Dr. João Nunes Nogueira
}

\section{RESUMO}

O presente trabalho objetivou avaliar a qualidade de cogumelos Pleurotus sajor-caju submetidos a acidificação e processamento térmico, e a desidratação.

$\mathrm{Na}$ acidificação, foram empregados cinco ácidos orgânicos (acético, cítrico, lático, málico e tartárico) e a adição de cloreto de cálcio, visando melhorar a textura do produto final. $\mathrm{Na}$ desidratação, foram utilizados diferentes tratamentos pré-processamento.

Foram realizadas análises fisicas, químicas, microbiológicas e sensoriais, após períodos de 30,60 e 90 dias de armazenamento à temperatura ambiente. Os resultados mostraram que a acidificação possibilita a obtenção de um produto de alta qualidade, por pequenas indústrias, utilizando equipamentos de baixo custo $\mathrm{e}$ pouca demanda de energia, e sem riscos à saúde do consumidor. A desidratação representa uma alternativa em períodos de picos de produção, uma vez que reduz volume e peso, aumentando a eficiência da armazenagem e do transporte, em relação ao produto com elevado teor de umidade. 


\section{PROCESSING OF EDIBLE MUSHROOMS (Pleurotus sajor-caju) BY ACIDIFICATION AND THERMAL TREATMENT AND BY DRYING}

Author : Mariana Sartori Nardin Adviser : Prof. Dr. João Nunes Nogueira

\section{SUMMARY}

A study was conducted on thermal processing of mushrooms acidified with five organic acids (acetic, citric, latic, malic and tartaric, with and without calcium) and on dried mushrooms submitted to diferent chemical treatments, before processing.

The quality of the processed mushrooms was evaluated by physical, chemical, microbiological and sensory analyses after one, two and three months storage period at room temperature.

The results indicated the possibility of processing high quality canned mushrooms by small industries, with low cost equipments and low energy requirements. The acidification procedure also ensure minimal health risk to the consumer. The drying process looks like also to be a good alternative to the agroindustry. 


\section{INTRODUÇÃo}

Os cogumelos são usados como alimento pelo homem há séculos, sendo atualmente conhecidas cerca de 600 espécies comestíveis. Destas, apenas 20 são utilizadas comercialmente em todo o mundo, sendo que as espécies Agaricus bisporus ("Champignon de Paris") e Lentinus edodes ("ShiitaKe") são as mais consumidas.

O Pleurotus sajor-caju, que é cultivado predominantemente na Europa e países do Oriente, tem a perspectiva de ser o terceiro mais cultivado, considerando-se os aumentos de produção, ano a ano, de acordo com Wood \& Smith (1987).

Na América Tropical, 38 espécies de Pleurotus são conhecidas, das quais 31 são consideradas comestíveis e podem ser cultivadas em uma variedade de materiais (Martinez-Carrera, 1989 e Martinez-Carrera et al., 1992).

$\mathrm{O}$ gênero Pleurotus é um fungo que pertence à sub-divisão Basidiomycotina, segundo Muchovej \& Muchovej (1989). Seu habitat natural constitui-se de florestas sub-tropicais e tropicais, onde vive saprofiticamente, decompondo madeira e outros resíduos vegetais. Atualmente há muitas espécies apontadas como apropriadas para cultivo em regiões brasileiras, principalmente: Pleurotus sp. "Florida", também conhecido como Pleurotus pulmonarius, Pleurotus sajor-caju, e Pleurotus ostreatoroseus. 
A falta de informações é grande, tornando-se dificil estimar o volume de cogumelos produzidos e comercializados no Brasil. Os dados disponíveis são subestimados, existindo referências apenas nos Boletins de Comercialização das Centrais Gerais de Abastecimento do Estado de São Paulo - CEAGESP e nas Publicações de Importações e Exportações Brasileiras da Carteira de Comércio Exterior - CACEX. A região da grande São Paulo é responsável por $95 \%$ do volume de vendas, sendo que o restante corresponde a outros municípios do próprio Estado, em sua maioria. A produção de cogumelos e seu volume de comercialização vêm aumentando aceleradamente nos últimos anos: atualmente, a produção brasileira de cogumelos está em torno de 12 toneladas diárias (Boletim CEAGESP/CACEX, 1996).

Segundo Sturion (1994), o gênero Pleurotus apresenta algumas razões para expansão de seu cultivo, no Brasil: apresenta alta habilidade de colonização e pode crescer em substratos a base de inúmeros resíduos agrícolas; requer um nível mínimo de controle ambiental, já que apresenta espécies adaptadas às regiões tropicais; suas técnicas de cultivo são menos complexas que as desenvolvidas para o cultivo do gênero Agaricus, que é o cogumelo mais cultivado e consumido no mundo; apresenta espécies comestíveis nativas no Brasil, que podem oferecer possibilidades de adaptações às nossas condições de cultivo; e, apresenta possibilidades de aproveitamento do substrato residual, como alimentos para animais, ou como fertilizantes para o solo, devido às suas qualidades nutritivas e alta digestibilidade.

O Pleurotus sajor-caju é considerado uma fonte adequada de vários nutrientes, entretanto, quando "in natura", constitui-se um alimento altamente perecível, que se deteriora rapidamente durante a comercialização, principalmente onde o emprego da refrigeração é deficiente. Conforme estudos de Bano \& Rajarathnam (1989), à temperatura de $21-25^{\circ} \mathrm{C}$, considerando-se os padrões 
comerciais de aparência, consistência, presença de bolor e deformação, a durabilidade dos cogumelos é de apenas um dia, com ou sem embalagens.

É imprescindível, pois, a aplicação de técnicas de processamento, visando aumentar a vida de prateleira ("shelf life") deste alimento.

Segundo "Food and Drug Administration" (1976), alimentos com pH superior a 4,6 são considerados alimentos de baixa acidez. A maioria das hortaliças se enquadra nesta categoria, assim como os cogumelos Pleurotus sajorcaju. Tais alimentos caracterizam-se por oferecerem condições ao desenvolvimento de microrganismos deterioradores termoresistentes, principalmente o Clostridium botulinum, bactériạ anaeróbica esporulada, produtora de uma neurotoxina altamente perigosa ao ser humano. Neste caso, devem ser empregadas temperaturas acima de $100^{\circ} \mathrm{C}$, para destruição dos esporos das bactérias, utilizando-se de autoclaves. Alguns alimentos, entretanto, não podem ser submetidos a temperaturas elevadas, sem sofrer drásticas alterações nas suas qualidades organolépticas e nutricionais.

O emprego da acidificação por adição de ácidos orgânicos, visando redução do $\mathrm{pH}$ abaixo de 4,6 , permite a esterilização a cerca de $100^{\circ} \mathrm{C}$ (água em ebulição), e se constitui em uma técnica alternativa para economizar energia durante o processamento e obter um produto final de alta qualidade, utilizando equipamentos menos sofisticados (Nogueira, 1991). No entanto, muitos vegetais apresentam alterações na textura (amolecimento), por serem muito sensíveis ao tratamento térmico. $\mathrm{O}$ cálcio é um elemento que age como um importante agente "mantenedor" de textura, em frutas e hortaliças, conferindo-lhes maior rigidez (textura). Por esta razão, o cálcio tem sido muito utilizado em pesquisas com frutas e hortaliças processadas pelo calor, visando preservar ao máximo, a textura destes produtos ( Van Buren, 1979; Fenjin He et al., 1989; Meurer \& Gierschner, 1992). 
Além do processamento térmico, a desidratação é outro método que visa aumentar o tempo de conservação dos alimentos, viabilizando, assim, melhor aproveitamento e consumo. A desidratação de produtos alimentares representa uma alternativa em períodos de picos de produção, uma vez que reduz volume e peso, tornando o armazenamento e o transporte mais eficientes. No caso do cultivo de Pleurotus sajor-caju, estes picos de produção são bastante evidentes.

Estudos experimentais de Jorge (1989) demonstram que dentre as características envolvidas na conservação de cogumelos, o teor de umidade para armazenamento representa o parâmetro mais importante a ser controlado. $\mathrm{Na}$ desidratação, além da redução do teor de umidade a níveis que garantam armazenagem segura, deve-se também considerar os aspectos energéticos, bem como os de qualidade do produto reidratado, de modo a preservar seu valor nutricional e seu sabor.

Assim sendo, utilizando-se de matéria-prima de boa qualidade e desenvolvendo tecnologia adequada para a obtenção de cogumelos acidificados/processados termicamente e cogumelos desidratados, será possível oferecer tanto ao mercado interno como ao externo, um produto de alta qualidade, beneficiando diretamente indústrias, produtores e consumidores. 


\section{OBJETIVO}

O presente trabalho de pesquisa teve como objetivo propôr o emprego de tecnologia simples (acidificação/processamento térmico e desidratação), visando a conservação de cogumelos da espécie Pleurotus sajor-caju. Pretende-se, assim, obter produtos de alta qualidade, a custos relativamente baixos, que possibilitem maior aproveitamento da produção, suprimento de mercados interno e externo, e maior atendimento às exigências dos consumidores. 


\section{REVISÃO DE LITERATURA}

\subsection{Considerações gerais}

Cogumelos frescos são brancos ou de cor amarelo-parda, desprovidos de sinais escuros sobre o píleo e pedúnculo. O véu é fechado, as lamelas são invisíveis pela visão superior dos mesmos, a superfície superior do píleo pode ser fortemente convexa e os pedúnculos podem ser roliços e alongados (Luh \& Kean, 1975).

Cogumelos frescos do gênero Pleuroths caracterizam-se por um estipe que pode ser pequeno ou longo (10-15 mm) ou mesmo estar ausente. Não possuem anel, e os corpos de frutificação parecem pétalas de flores, desenhando-se como conchas de ostras. O tamanho varia com a espécie e entre uma mesma espécie, dependendo das condições de cultivo (climáticas ou nutricionais), sendo que o mínimo é de 2 a $3 \mathrm{~cm}$ e o máximo de 15 a $25 \mathrm{~cm}$. A coloração das diferentes espécies também depende das condições de cultivo, sendo que podem ser branca, creme, marrom claro, cinza claro ou escuro, e rosa. Segundo Zadrazil \& Grabbe (1983), o tamanho do píleo alcança de 5 a $15 \mathrm{~cm}$ em madeira e $30 \mathrm{~cm}$ em palhas.

Sturion \& Ranzani (1997) descrevem que Pleurotus é o nome científico dado a um gênero de cogumelos que na natureza, pela função que desempenham, são chamados de fungos degradadores da madeira ou "fungos da podridão branca". Tecnicamente, sabe-se que os fungos da podridão branca têm a 
habilidade de degradar tanto a lignina como a celulose e a hemicelulose. Essa capacidade de degradação relaciona-se ao largo espectro de enzimas hidrolíticas e lignolíticas que permitem a esses cogumelos colonizar inúmeros materiais lignocelulósicos naturais.

A este grupo de fungos pertencem várias espécies e linhagens de Pleurotus, incluindo as comestíveis, que possuem características morfológicas e fisiológicas distintas. Pela Figura 1, é possível perceber que todas as espécies possuem, em comum, a forma em concha espatulada de seu chapéu - também denominado de píleo - e de sua estipe ou pé excêntrico.

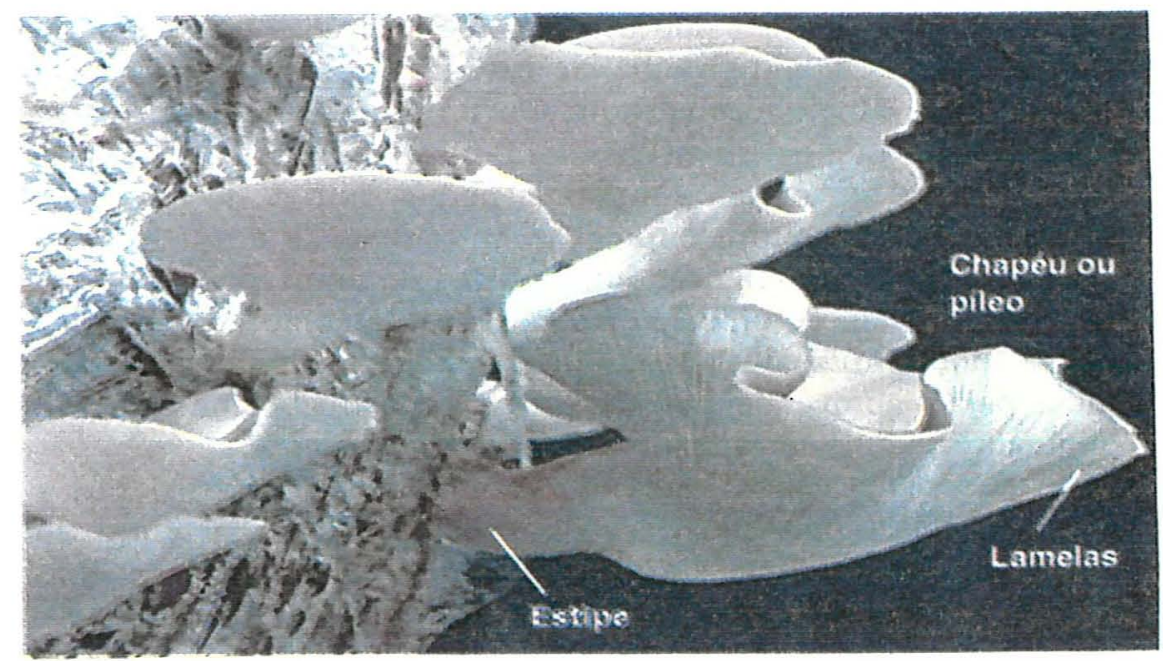

Figura 1. Partes do cogumelo Pleurotus sp. (Fonte: adaptado de Sturion \& Ranzani, 1997)

É preciso saber que várias espécies de Pleurotus comestíveis já são atualmente cultivadas. Dentre elas, as mais conhecidas são: a de coloração cinza e cinza claro, com temperatura de crescimento variando entre $15^{\circ}$ a $20^{\circ} \mathrm{C}$, 
denominada $P$. ostreatus; a de coloração branca e amarelada, que frutifica em cachos e desenvolve-se bem à temperatura de 26 a $27^{\circ} \mathrm{C}$, denominada $P$. sp "Florida", e, ainda outra de coloração cinza ou cinza a marrom escuro com temperatura de frutificação entre $25^{\circ}$ a $30^{\circ} \mathrm{C}$, denominada $P$. sajor-caju. Entre outras espécies e linhagens está o $P$. ostreatoroseus, uma espécie nativa de coloração rosa, como pode ser visto na Figura 2.

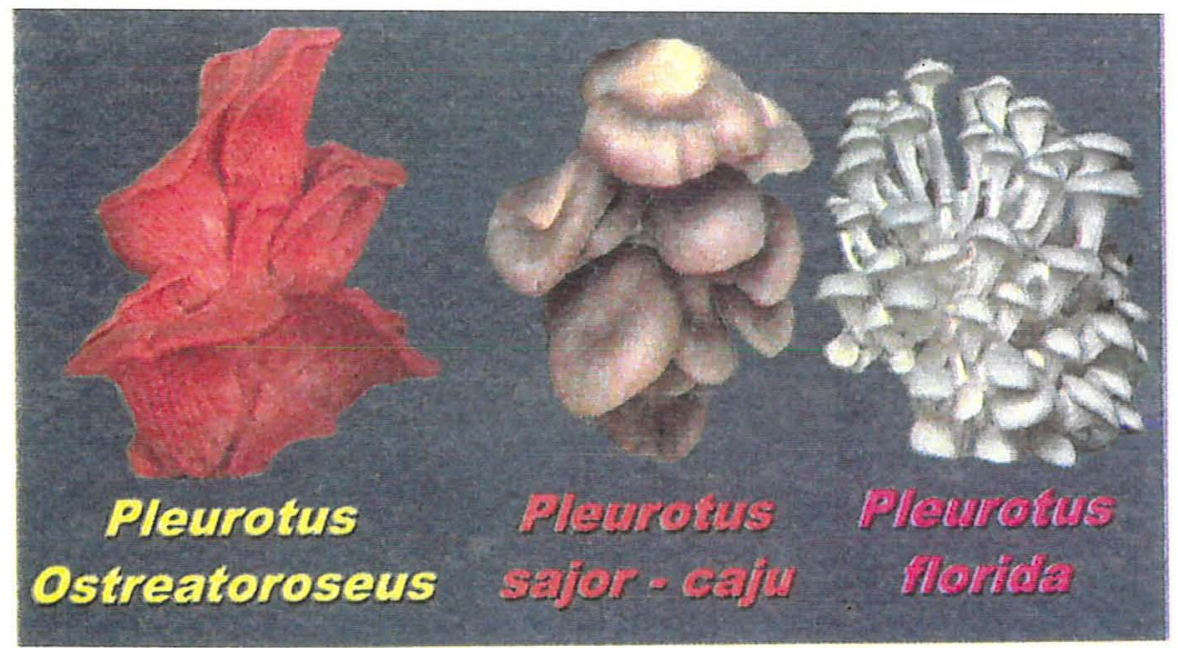

Figura 2. Pleurotus ostreatoroseus, $P$. sajor-caju e P. sp. "Florida" (Fonte: adaptado de Sturion \& Ranzani, 1997)

A espécie Pleurotus sajor-caju é um saprófito da madeira Euphorbia royleana e produz corpos de frutificação similares aos do Pleurotus sp. "Florida", de tonalidade marrom-clara. Primeiramente, foi cultivada em palha e pseudo caule de bananeira, segundo Zadrazil \& Grabbe (1983), e sua frutificação ocorre em altas temperaturas (cerca de $25-30^{\circ} \mathrm{C}$ ). 
Tanto o Pleurotus sp. "Florida"como o Pleurotus sajor-caju, além do Pleurotus ostreatus vêm sendo cultivados no Brasil há mais de 10 anos, de acordo com Bononi et al. (1991).

Métodos mais eficientes de armazenamento de cogumelos são muito importantes para a indústria, uma vez que cogumelos frescos são produtos altamente perecíveis. O período de aceitabilidade, em estado fresco, após a colheita, estende-se até cerca de cinco a seis dias (New, 1971; Chamarro et al., 1972; Komanowsky et al., 1970). O cogumelo (Pleurotus sp) apresenta maturação desuniforme, período de produção curto, e picos característicos de excedente de produção (Eira \& Minhoni, 1997). Por isso, a aplicação de alternativas de processamento torna-se extremamente favorável.

Segundo Gava (1985), a maioria dos produtos agrícolas se caracteriza pelo fato de serem sazonais, podendo, em determinadas épocas do ano, verificar o aparente fenômeno da superprodução. Isto, entretanto, não quer dizer que a produção agrícola seja superior à capacidade de consumo, pois o mercado consumidor geralmente se localiza em regiões relativamente distantes dos grandes centros de produção, o que torna o abastecimento com o produto fresco muito mais difícil, exigindo condições adequadas de manuseio, transporte e armazenamento.

Em se tratando de produtos altamente perecíveis, o melhor aproveitamento das safras só será possível através da introdução de processos eficientes de industrialização, que permitam a absorção de grande parte das colheitas, possibilitando seu consumo regular durante todo o ano (Gava, 1987; Evangelista, 1987).

Conforme Gill et al. (1969) e Luh et al. (1975), cogumelos que não forem processados imediatamente após a colheita devem ser armazenados sob refrigeração, em sacos plásticos, visando minimizar mudanças indesejáveis, tais 
como: abertura do véu, perda de peso e escurecimento. Salienta-se que o escurecimento enzimático, embora desejável para alguns produtos (chá, passas, ameixas) é altamente indesejável para a maioria dos produtos alimentícios, inclusive cogumelos (McCord \& Kilara, 1983).

Para o processamento, é necessário adaptar e selecionar os produtos, empregar, quando necessário, armazenamento refrigerado, bem como técnicas satisfatórias, a fim de que se possa oferecer ao mercado consumidor um produto que satisfaça as suas exigências, que se tornam cada vez maiores, com o passar dos anos (Fonseca \& Nogueira, 1989).

Segundo Gava (1978), a industrialização de produtos agropecuários pode contribuir consideravelmente para a melhoria da dieta de um país e do estado nutricional dos seus habitantes. A amplitude dessa contribuição depende de diversos fatores, como a existência de uma agricultura desenvolvida que possa receber tecnologias avançadas, bem como o nível e poder aquisitivo da população.

\subsection{Composição da matéria-prima}

Os cogumelos, em geral, têm sido consumidos há milênios devido ao seu sabor e aroma agradáveis e, mais recentemente, devido ao reconhecimento científico do seu valor nutricional e, em alguns casos, medicinal (Sturion, 1994).

Vários autores investigaram a composição centesimal de cogumelos comestiveis, e os resultados demonstraram grande variação, como está detalhado a seguir.

Segundo Carvalho (1995), a composição natural de um mesmo tipo de alimento pode variar muito com a procedência, variedade, trato cultural, etc. Além desta diferença natural, as vitaminas e minerais podem ser perdidos nas 
várias etapas de produção, distribuição ou mesmo preparo doméstico de um alimento.

No geral, cogumelos contêm proteínas (cerca de 3,5\%), carboidratos (cerca de $7 \%$ ), gorduras (cerca de $0,4 \%$ ), alguns compostos voláteis (5 a $15 \mathrm{ppm}$ ) e água (cerca de 88\%), conforme Angle \& Tamhane (1974) e Healt (1981), e são ricos em vitaminas, incluindo ácido ascórbico, tiamina, riboflavina, niacina e outras do complexo B, além de minerais, tais como: fósforo, sódio e potássio (Molena, 1986; Trufem \& Bononi, 1985).

Apesar dos cogumelos apresentarem qualidades nutricionais, seu consumo deve-se, principalmente, a seu sabor, que contribui para acentuar o gosto de certos produtos alimentícios, tais como sopas e molhos (Angle \& Tamhane, 1974). Inclusive, de acordo com Sturion \& Ranzani (1997), os cogumelos comestíveis não devem ser considerados como um alimento importante sob os pontos de vista energético e nutricional, mas sim importantes, devido à sua delicada textura $\mathrm{e}$ sabor característico que conferem aos pratos, onde participam como um dos principais ingredientes.

Segundo Crisan \& Sands (1978), mudanças significativas na composição química ocorrem com a espécie, idade ou estágio de desenvolvimento do corpo de frutificação. A composição varia também com o tempo de espera para a realização das análises assim como com as diferentes porções do mesmo corpo de frutificação. O tipo de substrato utilizado no cultivo também tem influência sobre a composição química do cogumelo, principalmente no conteúdo de proteína, minerais e nos constituintes do aroma e sabor (Chang et al., 1981).

Dados sobre o valor nutricional de cogumelos comestíveis são de difícil comparação porque muitos dos trabalhos não apresentam informações suficientes sobre as espécies, métodos de cultivo e métodos de análises, variáveis estas que 
afetam diretamente a composição química dos corpos de frutificação, de acordo com Bano \& Rajarathnam (1982).

\subsubsection{Umidade}

Os corpos de frutificação, em média, contém cerca de $90 \%$ de água, de acordo com Lau (1982) e Bano \& Rajarathmam (1988). Desvios significativos deste valor são reflexos das condições de cultivo tal como teor de água no substrato, temperatura ambiente e umidade relativa. $\mathrm{O}$ cogumelo seco comercializado apresenta de 10,0 a $12,0 \%$ de umidade, segundo Crisan \& Sands (1978).

\subsubsection{Carboidratos}

De acordo com Bano \& Rajarathnam (1988) os carboidratos representam o maior constituinte das espécies de Pleurotus, variando de 46,6 a $81,8 \%$ da matéria seca. Contém $4,2 \%$ de carboidratos solúveis, $1,7 \%$ de pentosanas e $32,3 \%$ de hexonas na base seca. Entre os carboidratos poliméricos estão o glicogênio (composto utilizado para estocagem de energia e presente no Pleurotus flabellatus em uma proporção de $8,9 \%$ ) e a quitina, um polímero de $\mathrm{N}$-acetilglucosamina, componente estrutural da parede celular fúngica e que é também considerado como sendo o maior constituinte do conteúdo de fibra do cogumelo. É este nitrogênio da quitina que contribui para o alto teor de proteína normalmente determinado por análises padrões que empregam o fator de conversão $\mathrm{N} \times 6,25$, de acordo com Crisan \& Sands (1978).

Muitos estudos vêm sendo realizados para caracterizar os componentes de polissacarídeos solúveis em água dos corpos de frutificação de espécies de 
Pleurotus, devido a sua habilidade de inibir o crescimento de tumores. Atividades contra a formação de tumores de cogumelos comestíveis, dentre eles, o Pleurotus ostreatus, foram investigadas por Mori et al., (1987), através de alimentação a ratos com dietas contendo de 10 a $30 \%$ de corpos de frutificação quando observaram uma redução do desenvolvimento destes. Zhuang et al. (1993) analisaram a atividade contra tumor de frações de polissacarídeos isolados de proteínas dos corpos de frutificação de Pleurotus sajor-caju e constataram a retração do tumor em rato, assim como o prolongamento da vida em 2,3 a 2,6 vezes quando comparado ao controle.

De um modo geral os cogumelos apresentam grande quantidade de fibra variando de 3,0 a $32,0 \%$, segundo Crisan \& Sands (1978), de 5,0 a $15,0 \%$ segundo Lau (1982), e de 7,5 a 27,6\% segundo Bano \& Rajarathnam (1982). Estudos realizados por Kurasawa et al. (1982) sobre o conteúdo de fibra em 26 espécies de cogumelos comestíveis obtiveram como resultados médios em base seca: $11,4 \%$ de celulose, $21,4 \%$ de hemicelulose, $2,9 \%$ de lignina, $3,7 \%$ de substâncias pécticas, $9,7 \%$ de fibra bruta e um total de fibra dietética de 39,4\%. Para o Pleurotus ostreatus, os autores encontraram $11,6 \%, 27,8 \%, 2,0 \%, 8,0 \%$ e $47,5 \%$, de cada um destes componentes, respectivamente.

\subsubsection{Proteínas}

O teor de proteína bruta do cogumelo varia de 8,9 a $38,7 \%$ na base seca de acordo com Bano \& Rajarathnam (1982), e de 15,0 a 50,0\% segundo Lau (1982), em média 19,8\% segundo Maziero (1990), valores estes obtidos com o fator de conversão N×4,38. De acordo com Crisan \& Sands (1978) e Bano \& Rajarathnam (1988), o fator de conversão $N \times 6,25$ utilizado para a maioria dos alimentos para o cálculo de proteína bruta é baseado na premissa de que a maioria das proteínas 
contém $16 \%$ de nitrogênio e considerando-se também que cerca de $100 \%$ desse nitrogênio é digerível. Outros pesquisadores indicam uma digestibilidade provável de 60 a $70 \%$ da proteína de cogumelo. Esta redução no coeficiente de digestibilidade pode ser parcialmente explicada pelo fato de que os cogumelos contém uma quantidade significativa de nitrogênio não protéico na forma de glucosaminas na parede celular quitinosa. Uma boa aproximação do teor de proteína bruta de cogumelo pode ser obtida usando-se o fator de conversão igual a $\mathrm{N} \times 4,38$ que representa $70 \%$ de $\mathrm{N} \times 6,25$.

Quando comparada à proteína do ovo, as espécies de Pleurotus são limitantes em aminoácidos sulfurados (metionina e cistina), aromáticos (fenilalanina e tirosina) e em leucina, segundo Bano \& Rajarathnam (1988). Cerca de 1/5 do nitrogênio total está na forma de aminoácidos livres sendo a alanina, o ácido glutâmico e a glutamina os predominantes no "pool" de aminoácidos livres.

Além da composição química da matéria prima utilizada como substrato, a adição de compostos orgânicos e inorgânicos tem um efeito significativo no conteúdo de proteína dos corpos de frutificação das espécies de Pleurotus. Bano et al. (1978) observaram que a suplementação da palha de arroz com pó de semente de algodão, após o crescimento micelial, produziu corpos de frutificação com teores mais altos de proteína quando comparados com os produzidos em palha de arroz sem suplementação, no cultivo de Pleurotus flabellatus. Zadrazil (1980) também observou um aumento no teor de nitrogênio dos corpos de frutificação do Pleurotus sajor-caju quando o substrato foi suplementado após período de incubação com alfafa e farinha de soja. O mesmo efeito foi observado por Bano \& Rajarathnam (1988).

Em seus estudos sobre o cultivo de Pleurotus, Sturion (1994) encontrou teores de proteína que variaram de 17 a $19 \%$, quando cultivados em substrato de folhas de bananeira. Nas espécies que foram cultivadas em tal substrato, os 
cogumelos apresentaram todos os aminoácidos essenciais, com limitações apenas em sulfurados, dependendo da espécie cultivada.

Os cogumelos não devem, pois, ser considerados como única fonte de proteína, mas como um item da alimentação de dietas de baixa caloria, servindo como proteína complementar, sendo incluídos no grupo de vegetais de alto teor protéico (Sturion, 1994).

\subsubsection{Lipídeos}

O teor de lipídeos em diferentes espécies de Pleurotus varia de 2 a $8 \%$ em base seca, segundo Crisan \& Sands (1978) e, em média contém 2,85\% de gordura, segundo Bano \& Rajarathnam $(1982,1988)$. O maior constituinte é o ácido olêico (79,4\%) seguido do palmítico (14,3\%) e ácido linolêico (6,3\%). Esqualeno e ergosterol (livre e esterificado) e ubiquinona-7 também estão presentes.

As concentrações relativamente altas de ácidos graxos insaturados, linolêico em particular, tornam as espécies de Pleurotus adequadas do ponto de vista nutricional por estes constituintes da dieta não serem sintetizados pelo corpo humano e contribuírem com a diminuição no nível de colesterol (Sturion, 1994).

\subsubsection{Cinza}

Os corpos de frutificação geralmente contém de 5 a $10 \%$ de cinza na base seca, segundo Lau (1982). Potássio (2\%) e fósforo $(0,75 \%)$ são os maiores constituintes nas espécies de Pleurotus; magnésio $(0,15 \%)$ representa o terceiro mineral em quantidade e o cálcio $(0,12 \%)$ e ferro $(0,05 \%)$ estão em baixa concentração, sendo que o ferro presente está na forma disponível, de acordo com Bano \& Rajarathnam (1988). 
A presença de metais pesados nos corpos de frutificação pode ser atribuída à contaminação dos substratos ou a seletividade do fungo a certos metais. Dos metais pesados o zinco é o que aparece em maiores quantidades em todas as espécies de Pleurotus apesar de estar contido nas palhas em baixa quantidade. Isto indica a tendência destes fungos de acumular este elemento nos corpos de frutificação, porém estas quantidades estão aquém do nível de tolerância para estes metais prescritos pela "Food and Agriculture Organization", segundo Bano \& Rajarathnam (1982).

Estudo realizado por Brunnert \& Zadrazil (1983) demonstrou a habilidade de fungos lignocelulolíticos em acumular altos níveis de cádmio e mercúrio, dentre eles, Pleurotus flabellatus, Pleurotus ostreatus e Pleurotus sajor-caju. Os dados revelaram também que as espécies que acumulam percentual maior de metais pesados são as que promovem maior taxa de degradação do substrato. $\mathrm{O}$ teor de cobre nunca excede àquele do substrato e o mercúrio e o cádmio podem ocorrer se o substrato estiver contaminado com estes metais.

\subsubsection{Vitaminas}

As concentrações de tiamina $(2 \mathrm{mg} / 100 \mathrm{~g})$, niacina $(40 \mathrm{mg} / 100 \mathrm{~g})$ e riboflavina $(4 \mathrm{mg} / 100 \mathrm{~g})$ em base seca, nas espécies de Pleurotus são, de acordo com Lau (1982) definitivamente superiores às encontradas em outros gêneros. O Pleurotus contém todas as vitaminas em grandes quantidades, com exceção do ácido ascórbico, quando comparado com outros vegetais. São boas fontes de riboflavina e ácido fólico (vitamina construtora do sangue que controla a anemia perniciosa). Além do que, segundo Bano \& Rajarathnam (1982), 70\% dos esteróis presentes em espécies de Pleurotus são representados pelo ergosterol que pode ser transformado em vitamina D sob luz ultravioleta. 


\subsubsection{Outros}

O valor energético do Pleurotus sajor-caju é de $336 \mathrm{Kcal} / 100 \mathrm{~g}$ em peso seco calculado pelos índices de conversão de 2,62, 8,37 e 3,48, respectivamente, para proteína bruta, lipídeos e carboidratos uma vez que estes componentes não são $100 \%$ digeríveis nos cogumelos (proteína $70 \%$; lipídeos $90 \%$ e carboidratos 95\%), de acordo com Crisan \& Sands (1978).

Segundo Bano \& Rajarathnam (1988), baseando-se nas recomendações de que a ingestão diária de ácidos nuclêicos não deve ultrapassar $4 \mathrm{~g}$, dos quais somente $2 \mathrm{~g}$ podem ser provenientes de proteína unicelular, o consumo diário de 200 a $250 \mathrm{~g}$ de Pleurotus fresco por pessoa não traz problemas de ordem nutricional como é o caso das leveduras e das algas. Quanto a presença de ácidos orgânicos, o Pleurotus contém traços dos ácidos lático e succínico enquanto que os ácidos fórmico e acético são dominantes. Os compostos químicos que podem contribuir para o aroma e sabor, que representam os fatores mais importantes de indução ao largo consumo de cogumelos comestiveis, são o ácido glutâmico (realçador de sabor), os ácidos graxos de cadeia curta e os caboidratos.

\subsection{Legislação}

De acordo com a Legislação Brasileira, no que tange ao Compêndio da Legislação de Alimentos, ABIA, os fungos designados cogumelos cultiváveis e comestíveis são descritos pela Resolução número 12, de 24 de julho de 1978.

As denominações, descrições e padrões impostos seguem abaixo. 


\section{LEGISLAÇÃO NACIONAL SOBRE O PRODUTO - BRASIL \\ Resolução no 12 de 24 de julho de 1978 \\ Compêndio da Legislação de Alimentos - ABIA}

\section{Definição}

Os cogumelos comestíveis são fungos pertencentes às classes dos ascomicetes e dos basidiomicetes. A espécie cultivada mais comum é o Agaricus bisporus (basidiomicetes).

\section{Designação \\ O produto é designado simplesmente "cogumelo".}

\section{Classificação}

a) Extra - Carpóforos inteiros, firmes, bem formados, véu fechado, tamanho uniforme, sem manchas ou marcas de parasitos. Quando lavados não devem apresentar odores estranhos (agentes branqueadores).

b) Comum - Carpóforos inteiros, firmes, sendo toleradas algumas manchas, tamanho e formato diversos.

\section{Características Gerais}

Os cogumelos comestíveis são constituídos por carpóforos não inteiramente desenvolvidos (botões) cortados pela base (não arrancados): sã̃o consistentes, isentos de manchas ou marcas de parasitos, e isentos da maior parte da matéria-terrosa. Não podem conter detritos de substrato usado para o cultivo. Não podem apresentar-se fermentados e quando lavados, não devem apresentar odores estranhos. Tolera-se o tratamento de cogumelos com solução de bissulfito de sódio como agente branqueador. O resíduo máximo de $\mathrm{SO}_{2}$ é de $50 \mathrm{ppm}$. 


\section{Características Organolépticas}

- Aspecto: botão (píleo) globular, irregular, com haste grossa.

- Cor: conforme a espécie, pode ser branco, creme ou marrom.

- Cheiro: próprio.

- Sabor: próprio.

\section{Características Microbiológicas}

Os cogumelos devem obedecer ao seguinte padrão:

- Bactérias do grupo coliforme de origem fecal - máximo de $2 \times 10^{2} \mathrm{UFC} / \mathrm{g}$.

- Salmonelas - ausência em $25 \mathrm{~g}$.

Deverão ser efetuadas determinações de outros microrganismos e/ou substâncias tóxicas de origem microbiana, sempre que se tornar necessária a obtenção de dados adicionais sobre o estado higiênico-sanitário desta classe de alimento, ou quando ocorrerem toxi-infecções alimentares.

\section{Características Microscópicas}

Ausência de sujidades, parasitos e larvas.

\section{Rotulagem}

Quando embalado, o rótulo deve trazer a denominação "cogumelo", em seguida de sua classificação, podendo conter também a designação "champignon", no caso de se tratar do gênero Agaricus. 
Convém ressaltar que a Legislação Brasileira, no que tange ao Compêndio da Legislação de Alimentos, ainda não definiu, com exatidão, as normas e/ou regras para cogumelos processados, de qualquer natureza.

\subsection{Fatores que afetam a qualidade dos cogumelos}

Não há como se pensar em um produto de boa qualidade, se no processo de obtenção deste não forem observadas condições adequadas de desenvolvimento e manejo.

Como acontece com outros cultivos tradicionais, o maior problema na produção de cogumelos (depois dos devidos ajustes das condições ambientais de umidade, ventilação, iluminação e temperatura) é devido à ocorrência de doenças e pragas. Além dos fungos, bactérias e vírus considerados parasitas propriamente ditos, há ainda que se considerar um certo número de fungos que, embora não sendo parasitas do cogumelo, ocorrem no substrato, reduzindo a quantidade de alimento disponível ou produzindo substâncias tóxicas que retardam o seu desenvolvimento. Estes, devido à forma e característica de atuação, são designados competidores. Com menor intensidade, podem aparecer ainda certos distúrbios ou doenças fisiológicas causadas por fatores ambientais, químicos ou físicos que levam ao desenvolvimento de lesões ou deformações (Figueiredo \& Mucci, 1985).

O cogumelo, a despeito do estágio de maturação que foi colhido, é composto por uma delicada massa de células agrupadas e assim como todos os organismos vivos, respira, cresce e senesce, sendo que a taxa de ocorrência destes fenômenos afeta a sua qualidade. O estudo da fisiologia pós-colheita busca 
descobrir o quanto estes processos fisiológicos podem ser alterados para manter a qualidade e durabilidade do produto.

Em geral, exige-se um produto sadio e limpo, que seria um cogumelo livre de resíduos, intacto e sem odores estranhos, fatores estes influenciados sobremaneira pelos métodos de cultivo, estocagem e comercialização (Berhardt, 1980).

Além disso, existem outras considerações usadas para indicar o frescor como a cor, turgidez e estágios de desenvolvimento do píleo e estipe, que são os principais parâmetros de qualidade a se considerar, no produto fresco (Jorge, 1989).

\subsubsection{Cor}

O impacto visual causado pela cor geralmente se sobrepõe ao causado pelos outros atributos sensoriais (sabor e textura), e isto porque as cores caracterizam sobremaneira os objetos, constituindo-se no primeiro critério aplicado para sua aceitação ou rejeição.

$\mathrm{Na}$ verdade, a arte de colorir os alimentos é extremamente importante para quem produz e para aqueles que os consomem, já que das cores, em grande parte, vai depender o sucesso ou o fracasso das vendas do alimento (Ferreira, 1991).

As linhagens de cogumelos cultivados têm suas hifas praticamente incolores, porém, contém enzimas que sob certas circunstâncias reagem com o substrato do conteúdo celular, formando compostos pigmentados. Com relação à qualidade, estas enzimas denominadas polifenoloxidases são responsáveis pela maior parte das reações de escurecimento em cogumelos (Jorge, 1989).

Sabe-se que a atividade metabólica de cogumelos frescos é diferente de espécie para espécie. Com relação ao escurecimento enzimático causado pela 
polifenoloxidase, seu efeito é menos sentido em Pleurotus, que em Agaricus ou mesmo em Lentinus. Uma das razões está na coloração natural do Pleurotus, que é mais escura, além do que a preferência do consumidor brasileiro é por um "champignon" de cor bem branca, com ausência total de manchas. Estudos de Bano \& Rajarathnam (1988) levam a concluir que comparativamente, a atividade da polifenoloxidase é bem inferior em Pleurotus que em Agaricus.

Segundo Bano \& Rajarathnam (1989), a tirosinase e a catecolase são enzimas distintas que agem em substratos específicos. $O$ escurecimento pressupõem que haja o contato entre a enzima, substrato e oxigênio. Assim, a prevenção da ruptura de tecidos (com liberação de enzimas), a inativação enzimática pelo aquecimento ou uso de $\mathrm{SO}_{2}$, assim como uma mudança de $\mathrm{pH}$ para um meio acidificado, podem reduzir o escurecimento enzimático.

\subsubsection{Conteúdo de água}

Os cogumelos são constituídos por uma quantidade de água ao redor de $90 \%$, quando da colheita, e não possuem qualquer estrutura física de prevenção de perda de umidade; como conseqüência, a perda de água sob a forma de evaporação é semelhante a evaporação de um espelho de água livre (Flegg et al., 1985). Uma conseqüência desta perda é o enrugamento do píleo e estipe, seguido de contração e enrijecimento. Estes sintomas estão associados diretamente com a perda de frescor dos cogumelos colhidos.

\subsubsection{Desenvolvimento}

Mesmo após ser colhido, o cogumelo continua seu processo de desenvolvimento, e é fácil notar um deslocamento de matéria seca do estipe para 
o píleo, que parece estar associado com a abertura da cobertura, quebrando o véu, com o crescimento e escurecimento das lamelas e finalmente a produção e liberação de esporos. Em cogumelos não colhidos também ocorre esta seqüência de fatos, porém o tamanho final destes é consideravelmente maior que os primeiros. A diferença deste processo em Pleurotus sp., é que este não apresenta véu (como o Agaricus sp., por exemplo), e o escurecimento das lamelas é reduzido.

Nichols et al. (1975), em seus experimentos com diferentes concentrações de dióxido de carbono e oxigênio no desenvolvimento de linhagens de Pleurotus, relatam que níveis de oxigênio abaixo do encontrado naturalmente (2-10\%) parecem promover o desenvolvimento do píleo e estipe. Somente a níveis inferiores a $1 \%$ de oxigênio, o crescimento é afetado.

\subsection{Conservação de cogumelos frescos}

De acordo com Paschoalino (1989), a seleção de linhagens, a região de cultivo, as práticas culturais, o estágio de maturação na colheita, bem como o manuseio do produto colhido antes do processamento são fatores importantes a serem considerados, uma vez que a matéria-prima é essencial para a qualidade e característica do produto final.

\subsubsection{Refrigeração}

Segundo Nichols (1985), a temperatura ótima de armazenagem para cogumelos é de 0 a $2^{\circ} \mathrm{C}$, sendo que o tempo de conservação irá variar de acordo com o tipo de cogumelo, e o estágio de desenvolvimento. Porém, de um modo geral, o cogumelo resfriado não resiste a esta temperatura por mais de dez dias, 
variando, na média, de 4 a 7 dias. No entanto, observa-se que o Pleurotus degrada-se mais lentamente que o Agaricus ou o Lentinus.

Além do resfriamento direto em câmaras frigoríficas, outros métodos também podem ser usados para promover o abaixamento da temperatura de cogumelos. Podemos citar o resfriamento à vácuo, no qual os cogumelos molhados com água são colocados sob vácuo, o que leva a uma rápida evaporação da água, roubando calor dos corpos de frutificação. Decorre também, uma desidratação dos cogumelos neste processo, com perda ao redor de $1 \%$ de umidade nos tecidos para cada $5^{\circ} \mathrm{C}$ de redução na temperatura (Flegg et al., 1985).

\subsubsection{Embalagem}

Cogumelos frescos devem ser geralmente embalados em bandejas (de isopor, por exemplo) revestidas por filme plástico, com orifícios, ou não (Bononi et al., 1995).

Nichols et al. (1975) em seus experimentos com conservação de cogumelos, relatam que um ambiente com concentrações em torno de 8 a $15 \%$ de $\mathrm{CO}_{2}$ e 1 a $2 \%$ de $\mathrm{O}_{2}$, dependendo do filme plástico em questão, pode ser alcançado em menos de 24 horas, a $18^{\circ} \mathrm{C}$. À esta temperatura $\left(18^{\circ} \mathrm{C}\right)$, sob tais condições de atmosfera, o produto mantém suas características intactas por 3 dias. Segundo os autores, a alta concentração de $\mathrm{CO}_{2}$ também inibiu o desenvolvimento do estipe.

Bano \& Rajarathnam (1988) observaram que existe uma relação ideal da quantidade de cogumelos e tamanho da embalagem para Pleurotus, pois diante de uma quantidade muito pequena de cogumelos, a concentração de $\mathrm{CO}_{2}$ será baixa, favorecendo a perda da coloração característica do produto e perda de firmeza na textura. Os melhores resultados foram obtidos, utilizando-se sacos de polietileno 
intactos, armazenados à $5^{\circ} \mathrm{C}$, onde após seis dias de estocagem, o produto mantinha ótimas características (semelhante ao produto fresco).

\subsubsection{Tratamento químico}

O tratamento químico de cogumelos é restrito ao Agaricus que é também o único a ser lavado antes de ser embalado. A lavagem é o método de remoção de restos de micélio e composto da superfície do cogumelo, que não causa danos às hifas, porém, favorece o escurecimento enzimático.

O tratamento químico é o mais utilizado no Brasil, segundo a Associação Brasileira de Cultivadores de Cogumelos - $\mathrm{ABC}$, para a manutenção da qualidade de cogumelos frescos. A técnica consiste na aplicação de metabissulfito de sódio, um agente redutor que previne a oxidação dos compostos fenólicos presentes nas hifas. Entretanto, seu uso em vários países é vetado por ser perigoso à saúde humana acima de determinada concentração.

A recomendação mais utilizada e que fornece ótimos resultados segundo Tada et al. (1992), consiste em lavar os cogumelos recém-colhidos, em solução de 100 litros de água, 100 gramas de bissulfito de sódio, 100 gramas de carbonato de cálcio e 100 gramas de ácido cítrico, deixando-os por alguns minutos. Esta solução é capaz de lavar $100 \mathrm{Kg}$ de cogumelos. Após terem o excesso de água escorrido, os cogumelos são colocados em embalagens plásticas.

\subsection{Processamento}

\subsubsection{Considerações gerais}


O Pleurotus é considerado uma fonte adequada de vários nutrientes, vitaminas e minerais. Entretanto, quando "in natura", constitui um alimento altamente perecível, que se deteriora rapidamente durante sua comercialização, principalmente onde o emprego da refrigeração é deficiente ou inexistente. Segundo Bano \& Rajarathnam (1989), a conservação do Pleurotus é totalmente assegurada em seus atributos de qualidade, somente em até 5 dias sob refrigeração (à temperatura de 3 a $6^{\circ} \mathrm{C}$ ). 1 partir destes cinco dias sob refrigeraçào, o resultado pode ser a oferta de um produto com atributos indesejáveis de qualidade, tais como coloração, e/ou textura e/ou sabor desagradáveis.

Segundo Martinez-Carrera et al. (1989), à temperatura de $21-25^{\circ} \mathrm{C}$, considerando-se os padrões comerciais de aparência, consistência, presença de bolor e deformação das bordas do píleo, a durabilidade dos cogumelos é de apenas um dia, com ou sem plásticos embalando-os. Embalados em sacos plásticos e armazenados a $8^{\circ} \mathrm{C}$, o tempo de armazenamento resfriado aumentou para 4 dias, e a $5^{\circ} \mathrm{C}$, aumentou para 8 dias. Convém ressaltar que 4 a 8 dias sob refrigerações é tempo deveras insuficiente entre a colheita, a comercialização e o seu consumo.

De acordo com Fonseca \& Nogueira (1989), a procura e aceitação de qualquer produto depende diretamente da sua qualidade. Daí a importância de se empregar no processamento, além de uma matéria-prima de boa qualidade, técnicas que permitam a máxima preservação das características que o produto possuía quando no estado fresco. O grau de alteração dos alimentos está condicionado a inúmeras causas, que podem estar ligadas à sua composição, à presença de enzimas e de microrganismos e a outros fatores, capazes de desencadear, neutralizar ou refrear o processo de deterioração (Caruso \& Camargo, 1984; Evangelista, 1987.) 
Segundo Chitarra \& Chitarra (1990), o controle de qualidade, tanto dos produtos destinados ao consumo direto, como daqueles para o processamento, tem como objetivo a obtenção de produtos com qualidade padronizada e constante, visando, principalmente, as vantagens econômicas básicas (minimização de custos e maximização de rendimento pela prevenção de defeitos), observando-se também os critérios de segurança de uso desses produtos. Para tal, o controle deve abranger todo o ciclo de produção, incluindo o produto, o material de embalagem, condições de armazenamento e/ou processamento e comercialização.

\subsubsection{Acidificação e processamento térmico}

Segundo "Food and Drug Administration"(1976), alimentos com pH superior a 4,6 são considerados alimentos de baixa acidez. A maioria das hortaliças se enquadra nesta categoria, assim como os cogumelos Pleurotus sajorcaju. Tais alimentos caracterizam-se por oferecerem condições ao desenvolvimento de microrganismos patogênicos, principalmente do Clostridium botulinum, bactéria anaeróbica esporulada, produtora de uma neurotoxina altamente perigosa ao ser humano. Neste caso, devem ser empregadas temperaturas acima de $100^{\circ} \mathrm{C}$, para destruição dos esporos das bactérias, utilizando-se a autoclave.

Algumas hortaliças, entretanto, não podem ser submetidas a temperaturás acima de $100^{\circ} \mathrm{C}$, sem sofrer alterações nas suas qualidades organolépticas e nutricionais. O emprego da acidificação por adição de ácidos orgânicos, visando redução do $\mathrm{pH}$ abaixo de 4,6 , permite a esterilização em água fervente, e se constitui em uma técnica alternativa para economizar energia durante 0 
processamento e obter um produto final de alta qualidade, utilizando equipamentos menos sofisticados (Nogueira, 1979).

Quando as hortaliças são acidificadas a $\mathrm{pH}$ inferior à 4,5 , elas podem ser processadas pela aplicação de calor suficiente apenas para destruir leveduras, bolores e bactérias não esporogênicas, uma vez que os esporos do Clostridium botulinum embora não sejam destruídos, permanecem dormentes pela adição do ácido apropriado, sendo inofensivos, nestas condições (Paschoalino, 1989).

A acidificação de alimentos de baixa acidez (via fermentação ou acidificação direta) permite o uso de tratamento térmico mais brando para se obter alimentos enlatados sem riscos à saúde (FPI, 1982).

$\mathrm{O}$ uso de tratamento térmico mais brando possibilita o enlatamento de alimentos sensíveis ao calor (como acontece com as hortaliças), porque com temperaturas mais baixas (ao redor de $100^{\circ} \mathrm{C}$ ) e pequenos intervalos de tempo resulta numa menor degradação térmica do alimento em relação ao processamento térmico convencional (autoclaves) para alimentos não acidificados (Leonard et al., 1986). Isto é possível porque com a redução do $\mathrm{pH}$ do meio a resistência dos microrganismos ao calor é também drasticamente reduzida.

A fermentação visando a redução do $\mathrm{pH}$ em hortaliças e que proporcione um produto de boa qualidade só pode ser obtida com um bom controle do processo e empregando-se os microrganismos adequados (Kotzekidou \& Roukas, 1987; Nogueira et al., 1991).

A acidificação direta para se obter um pH desejado pode ser feita com segurança se for conhecida a curva de acidificação do produto. Cada produto apresenta características próprias que são de fundamental importância para uma acidificação adequada, como por exemplo, a penetração de acidez e a variação do poder tampão. Quast \& Bernhardt (1976), constataram que o palmito não possui um poder tampão uniforme em toda sua extensão. Assim, para obter $\mathrm{pH} 4,3$ foram 
necessários 50 a $100 \%$ a mais de ácido cítrico para toletes provenientes da extremidade inferior, do que para aqueles da extremidade superior do mesmo creme. Os autores verificaram que as curvas de titulação variam notavelmente com a espécie do palmito. Portanto, a quantidade de ácido necessária para baixar o pH até um nível seguro, é dependente do poder tampão do produto e da constante de dissociação do ácido empregado.

Em princípio, qualcuer ácido permitido para uso em alimentos poderá ser empregado para a acidificação de um produto. Os ácidos, podem conferir a cada produto um sabor característico, além de sua acidez (Powers et al., 1960). Esse sabor é devido ao anionte do ácido. Além disso, a sensação de acidez resultante do emprego de cada ácido é variável, sendo principalmente uma função da constante de dissociação. Assim, o ácido tartárico, na mesma concentração, apresenta um gosto mais ácido que o lático. A escolha de um ácido ou outro, ou da sua combinação, dentre aqueles permitidos por lei, para a obtenção de um melhor sabor no produto, a um custo razoável, constitui ainda um vasto campo a ser pesquisado.

As hortaliças tem sido comumente processadas empregando-se métodos que requerem grandes gastos de energia como o congelamento e o processamento térmico em autoclaves (Anonymous, 1980). Considerando o alto custo da energia e dos equipamentos, Kosup \& Sistrunk (1982) sugeriram que estudos devem ser desenvolvidos no sentido de encontrar métodos alternativos que reduzam os custos e mantenham a qualidade desses produtos após o processamento. Segundo Fleming \& McFeeters (1981) e Nogueira et al. (1991) a fermentação e a acidificação parecem ser os métodos indicados para se atingir aqueles objetivos. A fermentação tem sido também utilizada para melhorar certos atributos de qualidade como o sabor e a textura (Kotzekidou \& Roukas, 1987). 
Trabalhando com acidificação de quiabo utilizando vários ácidos orgânicos ou por via fermentativa, Kotzekidou \& Roukas (1987) observaram que o melhor tratamento com relação à qualidade geral foi a fermentação. Kosup \& Sistrunk (1982) não encontraram diferenças significativas, quanto à qualidade geral, entre vagens acidificadas com ácidos orgânicos ou por via fermentativa, porém os tratamentos com ácidos málico, lático e cítrico obtiveram os melhores resultados quanto ao sabor. Para este atributo de qualidade a fermentação foi considerada o pior tratamento.

Heil \& McCarthy (1989) realizaram um experimento onde foi avaliada a textura objetiva de cenouras acidificadas e processadas termicamente, e observaram que a textura das cenouras acidificadas com ácido glucônico apresentavam-se mais firmes que as não acidificadas.

De acordo com FLeming \& McFeeters (1981), Nogueira et al. (1990 e 1991) e Meurer \& Gierschner (1992) a acidificação de hortaliças (adição de ácidos ou fermentação) para processamento térmico traz na prática várias vantagens, dentre as quais podem ser destacadas:

- Diminui a resistência dos microrganismos ao calor permitindo uma esterilização bem mais simples pelo emprego de temperaturas ao redor de $100^{\mathrm{c}} \mathrm{C}$ (água fervente). Isto possibilita às médias e pequenas indústrias bem como à própria indústria caseira de processar termicamente alimentos de baixa acidez com redução de custos, melhoria de qualidade e sem riscos para a saúde do consumidor.

- Economia no gasto de energia, na compra de equipamentos e instalações. Como conseqüência, o custo final do produto processado para o consumidor será bem melhor.

- A esterilização a cerca de $100^{\circ} \mathrm{C}$ evita ou reduz descolorações nos produtos. 
- O emprego de ácidos, como o cítrico por exemplo, evita ou reduz descolorações resultantes da ação de enzimas (polifenol oxidase) ou presença de metais (ferro, cobre, zinco e crômio).

- A fermentação ou a adição de ácidos orgânicos podem atuar como melhoradores do sabor para certos produtos quando processados pelo calor.

- Melhora de maneira significativa a textura das hortaliças processadas pelo calor.

Em trabalho de Matsuura et al. (1990) foi demonstrada a viabilidade econômica da instalação de uma agroindústria para o processamento térmico de cenoura acidificada.

No entanto, muitos vegetais apresentam alterações na textura (amolecimento), devido ao tratamento térmico a que são submetidos. Segundo Van Buren (1979), a textura é uma importante característica dos alimentos e o controle ou melhoria deste atributo constitui um dos principais objetivos da tecnologia de alimentos. O cálcio é um elemento que age como um importante agente "mantenedor" da textura, em frutas e hortaliças. Por esta razão, o cálcio tem sido usado em pesquisas com frutas e hortaliças processadas termicamente, visando preservar, ao máximo, a textura dos produtos (Van Buren, 1978; Fenjin He et al., 1989; Meurer \& Gierschner, 1992). A ação deste composto está relacionada com sua interação com a pectina dos vegetais dando formação ao pectato de cálcio que é estável ao calor.

Experimento realizado por Powers et al. (1950) com pimentão acidificado mostrou que a utilização de $\mathrm{CaCl}_{2}$ melhorou significativamente a textura do produto processado. Em trabalho semelhante, porém trabalhando com vagem, Fenjin He et al. (1989) também observaram este mesmo efeito. 
Saldana \& Meyer (1981) trabalhando com pimenta processada, relataram que o uso de $\mathrm{CaCl}_{2}$ resultou em produtos mais firmes em relação aos não tratados, além de não afetar o sabor e nível de vitaminas e minerais (exceto cálcio).

\subsubsection{Aditivos}

A presença de um produto no mercado depende, basicamente, da sua aprovação junto ao consumidor. Para isso, são feitos estudos prévios que determinam a plasticidade, aroma, cor, sabor, qualidade nutricional, etc. Todos esses itens são de extrema importância para a pesquisa e desenvolvimento do produto correto para o seu público alvo (Matérias - Primas..., 1994).

No Brasil, o Ministério da Saúde, através da Comissão Nacional de Normas e Padrões para Alimento (CNNPA), define um aditivo como a "substância ou mistura de substâncias, dotada ou não de valor nutritivo, adicionada ao alimento com a finalidade de impedir alterações, manter, conferir e/ou intensificar seu aroma, cor e sabor, modificar ou manter seu estado físico geral ou exercer qualquer ação exigida para uma boa tecnologia de fabricação do alimento"(Volpi, 1985).

Além das substâncias e elementos químicos presentes de modo natural nas matérias-primas alimentícias, outros produtos poderão ser incorporados às mesmas, direta ou indiretamente, durante o processamento, acondicionamento $\mathrm{e}$ transporte dos alimentos. São os chamados "aditivos", de composição química conhecida e intencionalmente adicionados em quantidades pequenas e controladas, com a finalidade de auxiliar o processo tecnológico, melhorar a qualidade organoléptica e aumentar o tempo de conservação dos produtos. Esses aditivos compreendem, entre outros, agentes inibidores de crescimento microbiano, antioxidantes, acidulantes, aromatizantes, corantes, estabilizantes e 
emulsificantes, e geralmente são codificados nos rótulos dos alimentos (Pavanello, 1990).

De acordo com Toledo (1986), o advento do uso de aditivos em alimentos, no começo deste século, trouxe à sociedade benefícios inegáveis, traduzidos principalmente no aumento da produção e disponibilidade de alimentos, na melhoria de suas propriedades funcionais e sensoriais, bem como em uma diminuição de custos. Porém, o seu emprego em alimentos somente é permitido após a consideração de diversos fatores que incluem a necessidade tecnológica do aditivo e, principalmente, o estabelecimento de sua segurança.

A utilização de aditivos ainda é um tabu, sobretudo pela falta de conhecimento a respeito da ação desses elementos. Em países mais desenvolvidos, onde as informações são, geralmente, passadas com maior clareza para o consumidor, o emprego de aditivos em geral, é um assunto que quase já não merece comentários. Mas são justamente os aditivos que permitem aumentar a vida útil ("shelf life") dos produtos, para que possam suportar, sem alterações em suas propriedades, longos períodos de transporte e de estocagem nos pontos de venda e nas próprias residências dos consumidores (Sucos..., 1989).

Gava (1987) afirma que, por várias razões, generalizou-se na mente da população leiga, e até na de muitos profissionais da área de alimentos, a idéia da quimiofobia, aceitando-se que aquilo que é químico é ruim, e o que é natural, é bom. É uma generalização sem fundamento científico, pois todo material do universo é de natureza química, não somente os aditivos, mas todos os alimentos, o nosso corpo humano e todo o ambiente. É preciso analisar cada substância química individualmente, seja de origem natural ou sintética.

De acordo com Nazário (1988), desde que se respeitem os limites estabelecidos pela legislação, todos os aditivos alimentícios, sem exceção, são inofensivos à saúde. Da mesma forma, é importante frisar que qualquer substância 
que compõe uma dieta alimentar, seja de origem natural ou não, poderá provocar prejuízos à saúde se ingerida em quantidades excessivas. Assim, conclui-se que tudo o que consumimos em excesso pode ser tóxico ou provocar danos ao organismo, mesmo em se tratando de produtos de consumo diário, com os quais já estamos habituados.

Sem os aditivos seria praticamente impossível a evolução da indústria de alimentos, e hoje talvez não tivéssemos a diversificação de produtos alimenticios que estão disponíveis no mercado (Pavanello, 1990). A necessidade de seu uso, porém, vem sendo ampliada com o desenvolvimento tecnológico, que faz as indústria sofisticarem seus produtos para atender um mercado cada vez mais pressionado pela concentração crescente das populações e por alterações constantes nos hábitos de vida (Nazário, 1988).

Segundo o Ministério da Saúde do Brasil, através da Comissão Nacional de Normas e Padrões para Alimentos (CNNPA), os acidulantes compreendem ácidos orgânicos ou não, que têm as funções de: conferir gosto ácido; controlar o pH; controlar desenvolvimento microbiano; e possuir ação seqüestrante de cátions que catalizam reações de oxidação. Os acidulantes são designados pela letra $\mathrm{H}$, seguida de um número em algarismos romanos (exemplos: ácido cítrico $=\mathrm{H} \mathrm{II}$; ácido lático $=$ H III; ácido tartárico $=$ H IX).

\subsubsection{Desidratação}

Além do processamento térmico, a desidratação é outro método que também visa aumentar o tempo de conservação dos alimentos, viabilizando, assim o aumento de produção, e consequentemente, de consumo. 
Dentre as características envolvidas na conservação de cogumelos, o teor de umidade para armazenamento representa o parâmetro mais importante a ser controlado (Jorge, 1989).

A desidratação, além de reduzir o teor de umidade a níveis que garantam armazenagem segura, deve também levar em conta, os aspectos energéticos, bem como os de qualidade do produto reidratado, de modo a preservar seu valor nutricionat e seu sabor (Bartholomai, 1974).

Conforme Gill et al.1969 ${ }^{1}$, citados por Luh \& Kean (1975), cogumelos que não forem processados imediatamente após a colheita devem ser armazenados sob refrigeração, em sacos plásticos, visando a minimizar as mudanças indesejáveis, tais como: abertura do véu, perda de peso e escurecimento. Salienta-se que o escurecimento enzimático, embora desejável para alguns produtos (chá, passas, ameixas), é altamente indesejável para a maioria dos produtos alimentícios (McCord \& Kilara, 1983).

\subsubsection{Secagem}

Tanto a secagem natural quanto a artificial são utilizadas, visando à conservação de cogumelos, segundo Jorge (1989).

Algumas informações sobre a secagem artificial de cogumelos cultivados são disponíveis na literatura. Chamarro et al. $1972^{2}$, citados por Fang et al. (1971), recomendaram o branqueamento de cogumelos, visando à inativação de enzimas, antes da secagem, cuja faixa de temperatura indicada é de 60 a $66^{\circ} \mathrm{C}$.

\footnotetext{
${ }^{1}$ GILL, W.J.; NICHOLAS, R.C.; MARKAKIS, P. Irradiation of cultured mushrooms. Food Technology, v.23, p.385-388, 1969 .

${ }^{2}$ CHAMARRO, J.; LAFUENTE, B.; LONGÁS, J.F.; PINAGA, F. Liofilizacion de champinones. I. Influencia de las variables de processo sobre la velocidad de secado. Agroquimica y Tecnologia de Alimentos, v.12, n.3, p.450-455, 1972.
} 
Komanowsky et al. (1970), investigando o efeito do branqueamento sobre o sabor, cor, estabilidade do produto durante a armazenagem e sobre a população de bactérias em cogumelos desidratados, concluíram que cogumelos branqueados escureciam durante a secagem artificial, ao passo que cogumelos nãobranqueados originavam, após secagem, produtos com sabor aceitável e estabilidade durante a armazenagem.

Conforme Luh et al. (1975), antes da operação de secagem, os cogumelos devem sofrer uma lavagem completa, ser cortados ou não em pedaços, e, em seguida, sofrer um branqueamento em vapor ou em água fervente, por um período de dois a cinco minutos. A temperatura do ar de secagem não deve ser superior a $65^{\circ} \mathrm{C}$ e o teor de umidade do produto deve ser reduzido para cerca de 0,053 base seca (b.s.) ou 5\% base úmida (b.u.).

$\mathrm{O}$ teor de umidade do produto para armazenagem deve ser entre 4 e $8 \%$ b.u.. Teores de umidade inferiores a $4 \%$ b.u. dificultam a reconstituição do cogumelo e o produto toma-se pobre em sabor, especialmente quando seco sob temperatura elevada. Após a secagem, o produto deve ser embalado em recipientes herméticos, visto que teores de umidade superiores a $10 \%$ b.u. favorecem variações na coloração e alteração no sabor (Komanowsky et al., 1970).

Cogumelos submetidos à secagem artificial são encontrados em certas regiões da Europa Central e Oriental. A secagem é conduzida, normalmente, em estufas ou em secadores tipo túneis. No início da operação de secagem, a temperatura atinge cerca de $60^{\circ} \mathrm{C}$ e, no final, cerca de $74^{\circ} \mathrm{C}$ (Angle \& Tamhane, 1974).

O fenômeno de escurecimento em cogumelos está associado a enzimas que catalisam a oxidação de substâncias fenólicas (Komanowsky et al., 1970). A prevenção desse fenômeno é um dos mais importantes problemas encontrados no 
processamento de cogumelos (Luh et al., 1975). De maneira geral, os métodos mais utilizados para inativar as enzimas em cogumelos são as operações de branqueamento e o tratamento com $\mathrm{SO}_{2}$, que, de maneira geral, são também aplicados às frutas e às hortaliças, antes da desidratação (Fang et al., 1971; Cantarelli et al., 1984).

\subsubsection{Branqueamento e tratamento químico}

A utilização de ar aquecido para secagem de cogumelos, previamente branqueados, causa modificações indesejáveis, tanto na cor quanto na forma do produto seco. A operação de branqueamento propriamente dita reduz os sólidos em cerca de $20 \%$, além de causar perda de nutrientes e de sabor (New... 1971). Por outro lado, essa operação remove gases dos tecidos, reduz a contagem microbiana e fixa cor e textura, além de inativar as enzimas (Luh \& Kean, 1975; Evangelista, 1987; Fonseca \& Nogueira, 1989).

Fang et al. (1971) observaram que alguns sólidos, tais como: aminoácidos, açúcares, minerais, componentes do sabor e outros componentes solúveis em água, perdem-se durante o processo de branqueamento do cogumelo.

Desphande \& Tamhane (1981), têm recomendado branqueamento com vapor, como pré-tratamento para cogumelos. Segundo estes autores, cogumelos branqueados pela imersão em água fervente, resultaram em um produto desidratado, de textura muito dura e de baixa aceitabilidade.

Dióxido de enxofre tem sido utilizado para reter a cor e permitir maiores temperaturas na desidratação de alimentos (Desphande \& Tamhane, 1981). Em cogumelos, em particular, pode resultar em um importante pré-tratamento, pois pode contribuir para que o produto, após sua reconstituição, seja de cor e de sabor aceitáveis ou mesmo desejáveis. Controlando a concentração da solução de 
metabissulfito de sódio e o tempo de imersão nesta, pode-se, em conseqüência, obter um produto desidratado de boa qualidade. Entretanto, o nível de $\mathrm{SO}_{2}$ pode ser minimizado, visando à obtenção de melhor sabor (Fang et al., 1971). Conforme Komanowsky et al. (1970), o teor de sulfito residual no produto deve ser abaixo de 100 ppm, pois concentrações maiores causam sabor desagradável para algumas pessoas.

Fang et al. (1971) concluíram que a atividade da polifenoloxidase em cogumelos em fatias foi inibida, utilizando-se um dos métodos: imersão em solução de metabissulfito de sódio, que continha $200 \mathrm{ppm}$ de $\mathrm{SO}_{2}$, por 10 minutos; imersão em solução de $2 \% \mathrm{NaCl}$, por 10 minutos, e branqueamento com água fervente, por dois minutos, seguido de resfriamento com água sob temperatura ambiente.

\subsection{Tendências de consumo - Avaliação econômica}

De acordo com Sturion \& Ranzani (1997), o aumento significativo na produção e no consumo dos cogumelos comestiveis em todo o mundo, nos últimos anos, deve-se a algumas causas específicas. Entre as causas detectadas é possível se mencionar o reconhecimento de seu valor nutricional, a exigência de pequenas áreas para seu cultivo com alta eficiência de bioconversão e o aspecto de auxílio à diminuição da poluição ambiental, em função das novas possibilidades de emprego do substrato residual.

Segundo dados do IBGE, em 1983/1984, o Pleurotus representava 2,15\% do total de produção mundial de cogumelos; em 1991 alcançava $21,5 \%$, ou seja, um aumento de $442,6 \%$ em volume total produzido. Os principais países produtores são o Japão, Taiwan, Itália, França, Alemanha, Holanda, Bélgica, China, Índia, Tailândia e Indonésia. Em anos mais recentes outros países 
passaram a produzir o Pleurotus para o consumo, como a Hungria, Austrália, Canadá, Nigéria, Estados Unidos e México.

Dados da CEAGESP/CACEX (1995) revelam que nos Estados Unidos o valor comercial dos cogumelos especiais, incluindo Pleurotus, alcançou valores de venda maiores que o cogumelo do gênero Agaricus (champignon de Paris), mundialmente mais cultivado e consumido. Em 1993, o cultivo do Pleurotus, embora ainda pequeno, gerou cerca de 2,587 milhões de dólares com prę̧o médio de venda de 6 dólares o quilo.

Especialistas da área de cultivo e comercialização de cogumelos apostam na expansão deste mercado e prevêem que nos próximos 10 anos o consumo de cogumelos, em geral, será ao redor de 30 a $40 \%$ maior que o atual. Além de sua popularização na indústria alimentícia, há perspectivas de um maior aproveitamento na indústria farmacêutica e de cosméticos devido ao seu teor de vitamina $\mathrm{B}$. Deve se ressaltar, novamente, os aspectos relacionados à melhora da poluição ambiental devido ao emprego de resíduos agroindustriais.

Sturion \& Ranzani (1997) afirmam que a América do Sul pode ser um mercado promissor pois ainda não possui produção suficiente para seu autoabastecimento, atuando como um mercado importador e limitado.

No Brasil, a produção de cogumelos é difícil de ser avaliada. No entanto, segundo os poucos dados disponíveis da Associação Brasileira de Cultivadores de Cogumelos - ABC (1995), sabe-se que 90\% dos produtores dão preferência ao cultivo do Agaricus bisporus, enquanto alguns poucos dedicam-se ao cultivo do Pleurotus e do Lentinus edodes, mais conhecido como shiitake.

Mas, a tendência no aumento da produção e consumo de cogumelos pode ser observada também no Brasil nesses últimos anos. Entre 1980 e 1995, o número de indústrias processadoras de cogumelos aumentou de 16 para cerca de 42. A maior região de produção, Mogi das Cruzes, registrava 100 produtores em 
1980 e, em 1995, contava com 300 cadastrados. Em 1980, a produção oficial foi de 2000 toneladas e, em 1995, foi estimada em 4800 toneladas, das quais 130 toneladas são referentes à produção do Pleurotus, que, nesse ano, contou com 25 produtores cadastrados. Foram apontados como principais estados produtores São Paulo, Rio Grande do Sul e Rio de Janeiro.

Segundo especialistas, o Brasil ainda hoje ocupa um lugar modesto na exportação de cogumelos, encuanto (que, em termos de importação, o cogumelo não é colocado como item prioritário. Mas, de acordo com os dados da Associação Brasileira de Cultivadores de Cogumelos - ABC (1997), a situação de importação do cogumelo seco ou desidratado mostrou aumento considerável entre 1991 e 1995.

As estatísticas indicam que em 1991 foram importados $17.408 \mathrm{Kg}$ de cogumelos secos e, em 1995, já se chegava aos $90.940 \mathrm{Kg}$. Estes números não se referem aos cogumelos do gênero Agaricus, pois estes não se prestam a esse tipo de conservação, sendo utilizados o Pleurotus e o Lentinus, entre outros, mais adequados. Um dos fatores que possivelmente tenha incrementado as importações é que o custo de cogumelos desidratados é superior ao importado, no Brasil. Essa discrepância pode ser decorrente da escassez desses cogumelos especiais no nosso mercado, enquanto na Ásia e Europa eles são relativamente abundantes.

Segundo levantamento de Sturion \& Ranzani (dados de setembro/1997), o Pleurotus sajor-caju têm sido vendido pelo mercado, ao consumidor final, a preços que variam de $\mathrm{R} \$ 8,00$ a $\mathrm{R} \$ 12,00$ o quilo do cogumelo fresco refrigerado. O quilo desse cogumelo seco custa cerca de 10 vezes mais que o quilo do fresco. Isso significa que, em se trabalhando com 2 toneladas/mês de folha de bananeira seca retirada do bananal, pode-se alcançar, em condição de cultivo de custo mínimo rústico, ao redor de 1 a 1,5 por tonelada de cogumelo fresco/mês $(50 \%$ de produtividade). Se o total de cogumelos for vendido diretamente por $\mathrm{R} \$ 8,00$ a $\mathrm{R} \$$ 
12,00 o quilo, haverá uma receita bruta de $R \$ 8.000,00$ a $R \$ 12.000,00 / \mathrm{mês}$. Considerando-se as perdas, despesas fixas e variáveis, depreciação, funcionários, etc, um índice considerado aceitável de cálculo para receita líquida estará ao redor de $20 \%$, o que resultará em $\mathrm{R} \$ 1.600,00$ a $\mathrm{R} \$ 2.400,00 / \mathrm{mês}$.

$\mathrm{Na}$ região de Mogi das Cruzes-SP, os maiores gastos têm estado relacionados à mão-de-obra e principalmente à matéria-prima do substrato de cultivo, que representa $42,32 \%$ do total de gastos. 


\section{MATERIAL E MÉTODOS}

As atividades desta pesquisa foram conduzidas em laboratório do Departamento de Agroindústria, Alimentos e Nutrição da Escola Superior de Agricultura "Luiz de Queiroz" - ESALQ/USP - Campus de Piracicaba.

\subsection{Matéria-prima}

No presente trabalho foi utilizada a espécie de cogumelo Pleurotus sajorcaju.

Os cogumelos foram recebidos no laboratório do Departamento de Ciência e Tecnologia Agroindustrial, em lotes de $15 \mathrm{Kg}$, provenientes de culturas da cidade de Salto (região de Itú), Estado de São Paulo.

A espécie Pleurotus sajor-caju foi selecionada para a realização deste trabalho de pesquisa, por se tratar de um material em fase de implantação de cultivo no Estado de São Paulo, não estando, até então, incluída em pesquisas sobre processamento; por se tratar de uma alternativa rentável em áreas pequenas; e, por possuir características favoráveis para a elaboração de conservas acidificadas e produtos desidratados, conforme resultados obtidos em testes preliminares.

Os lotes de matéria-prima foram recebidos no laboratório no mesmo dia da colheita, sendo mantidos sob refrigeração $\left(3-4^{\circ} \mathrm{C}\right)$ até o início do processamento, 
que se deu dentro de um período máximo de 48 horas após o recebimento dos mesmos.

\subsection{Caracterização da matéria-prima}

\subsubsection{Análises físicas}

a) Rendimento: Para as determinações de rendimento da matéria-prima, foram utilizadas amostras de $1000 \mathrm{~g}$ de cogumelos, tomadas aleatoriamente dos lotes do material.

Inicialmente, os cogumelos foram pesados em balança semi-analítica. A seguir, foram selecionados, limpos, lavados em água corrente e drenados por 15 minutos, sendo então, novamente pesados. Os resultados foram expressos em porcentagem do peso da matéria-prima pronta para o processamento (posteriormente, à sua “toalete"), em relação ao seu peso original.

b) Textura: Para as determinações objetivas da textura dos cogumelos "in natura" foi utilizado o texturômetro "Texture Testing System" modelo TP-1, acoplado a um registrador automático de variações de força, operando com célulapadrão de cisalhamento e compressão CS-1, com 10 lâminas de 1/8 polegada de espessura e ângulos de $90^{\circ}$. $\mathrm{O}$ instrumento estava provido de um sensor eletrônico de $300 \mathrm{lbf}$ e a velocidade de descida do pistão foi de $20 \mathrm{~cm} / \mathrm{min}$.

As amostras foram pesadas (40 $\mathrm{g}$ de cogumelos inteiros) e colocadas ao acaso na célula-teste. Os resultados foram expressos em libra-força por grama de amostra.

\subsubsection{Análises químicas}

a) pH: Foi determinado em potenciômetro digital Alphalab, modelo PA 
200.

b) Acidez total titulável: $\mathrm{Na}$ determinação da acidez total titulável, $10 \mathrm{~g}$ de matéria-prima triturada e homogeneizada foram diluídas em $90 \mathrm{ml}$ de água destilada, e tituladas com solução de hidróxido de sódio $0,1 \mathrm{~N}$ padronizado, tendo como indicador a fenolftaleína 1\%, conforme Kanesiro et al. (1982).

Segundo método de referência número 22060 da "Association of Official Analytical Chemists"- AOAC (1985), os resultados devem ser expressos em porcentagem de ácido presente em maior quantidade na matéria-prima. Assim sendo, os resultados de acidez foram expressos em gramas de ácido cítrico/100 $\mathrm{g}$ de amostra, por se tratar do ácido presente em maior quantidade em cogumelos da espécie Pleurotus sajor-caju.

c) Sólidos solúveis totais: Foram determinados por refratometria e expressos em graus Brix ( ${ }^{0}$ Brix ), após extração do suco celular, pela trituração e compressão da matéria-prima, de acordo com Tressler \& Joslyn, (1961). O refratômetro utilizado foi o ATAGO, modelo N-1.

Todas as análises físicas e químicas da matéria-prima foram efetuadas com duas repetições, utilizando amostras tomadas aleatoriamente, dos lotes de cogumelos. Os resultados da matéria-prima foram apresentados através de médias com seus respectivos desvios-padrão, correspondentes às repetições.

\subsection{Processamento}

\subsubsection{Acidificação e Processamento Térmico}

As operações realizadas para a obtenção do produto acidificado e processado termicamente estão indicadas na Figura 3. 


\section{a) Recebimento, corte da porção final do talo e seleção}

A matéria-prima foi recebida no laboratório acondicionada em bandejas de isopor recobertas com filme plástico, contendo $1000 \mathrm{~g}$ de cogumelos, em cada uma delas. Após recebimento, os corpos de frutificação tiveram a porção terminal de seus pedúnculos retirada, e foram imediatamente selecionados. A remoção da porção final do talo dos cogumelos visou individualizar os corpos de frutificação, e livrar a matéria-prima de algum resíduo proveniente do substrato em que foi cultivada. Tal operação foi realizada manualmente, com uso de facas. A seleção da matéria-prima objetivou a retirada de cogumelos cujo estado pudesse denegrir o produto final: cogumelos amassados, danificados, com lesões físicas. A seleção objetivou, também, homogeneizar o produto quanto ao tamanho, partindo-os, quando necessário.

\section{b) Lavagem, drenagem e branqueamento da matéria-prima}

Após a seleção, os cogumelos foram lavados em água corrente, para eliminação de impurezas, e drenados em peneiras de aço inox de malha $\mathrm{n}^{\circ} 8$, por 15 minutos. Amostras suficientes destinadas às análises físicas e químicas da matéria-prima foram retiradas após lavagem e drenagem.

A operação de branqueamento foi efetuada pela imersão dos cogumelos em solução de $\mathrm{NaCl}$ a $1,5 \%$ a $90^{\circ} \mathrm{C}$, por 2 minutos. A relação, em peso, matériaprima/água foi da ordem de $1 / 10$. O tempo de branqueamento utilizado (2 minutos) foi determinado em testes preliminares realizados com a matéria-prima: teste da polifenoloxidase e teste da peroxidase (Fonseca \& Nogueira, 1989).

\section{c) Tratamento de pré-processamento - acidificação}

Após o branqueamento, a matéria-prima pronta para o processamento (15 $\mathrm{Kg}$ ) foi dividida em dez lotes iguais $(1,5 \mathrm{Kg})$. Estes lotes foram, então, 
submetidos aos diferentes tratamentos de acidificação: quantidades suficientes de ácido acético, ácido cítrico, ácido málico, ácido lático e ácido tartárico foram adicionadas à salmoura de enlatamento ( solução de $\mathrm{NaCl} 1,5 \%$ ), para que o $\mathrm{pH}$ de equilíbrio no produto atingisse o valor de 4,3 - valor referência onde não há possibilidade de desenvolvimento do Clostridium botulinum. A concentração de ácido na solução salina foi calculada pela curva de acidificação do produto com cada ácido utilizado, determinada de acordo com a técnica estabelecida por Zapata \& Quast (1975).

Para se observar o efeito do cálcio na textura final do produto acidificado, cada tratamento teve metade de suas amostras $(0,75 \mathrm{Kg})$ adicionadas de $\mathrm{CaCl}_{2}$ à salmoura, na proporção de $0,5 \%$, em relação ao peso do produto. A Figura 4 ilustra os tratamentos.

Assim sendo, os tratamentos puderam ser definidos:

Tratamento 0 (T0): Testemunha

Tratamento 1 (T1): Cogumelos + ácido acético

Tratamento 2 (T2): Cogumelos + ácido acético + cloreto de cálcio

Tratamento 3 (T3): Cogumelos + ácido cítrico

Tratamento 4 (T4): Cogumelos + ácido cítrico + cloreto de cálcio

Tratamento 5 (T5): Cogumelos + ácido málico

Tratamento 6 (T6): Cogumelos + ácido málico + cloreto de cálcio

Tratamento 7 (T7): Cogumelos + ácido lático

Tratamento 8 (T8): Cogumelos + ácido lático + cloreto de cálcio

Tratamento 9 (T9): Cogumelos + ácido tartárico

Tratamento 10 (T10): Cogumelos + ácido tartárico + cloreto de cálcio

\section{d) Acondicionamento, recravação e tratamento térmico do produto}

$\mathrm{O}$ acondicionamento foi realizado a quente $\left(90^{\circ} \mathrm{C}\right)$, em copos de vidro com capacidade de $250 \mathrm{~g}$. Assim, em cada copo foram colocadas $150 \mathrm{~g}$ de cogumelos branqueados e $100 \mathrm{ml}$ de salmoura acidificada, deixando-se um espaço livre de 
aproximadamente $4 \mathrm{~mm}$. Os copos devidamente preenchidos foram fechados em recravadeira mecânica modelo "Rojek" - série "J", e imediatamente imersos em água fervente. O tipo de tampa utilizado foi tampa metálica semi-flexível, revestida internamente com verniz epoxi, própria para produtos ácidos; e que permite a exaustão durante o tratamento térmico, pela dilatação causada pelo calor. A esterilização comercial (tratamento térmico) foi obtida pela imersão dos copos, devidamente fechados e recravados, em água fervente $\left(97^{\circ} \mathrm{C}\right.$, em Piracicaba), por 20 minutos.

\section{e) Resfriamento e armazenamento}

O resfriamento foi realizado imediatamente a seguir, através da imersão dos vidros em tanques sucessivos de água, cujos valores de temperatura eram gradualmente menores, evitando-se deste modo, possíveis quebras devidas à choques térmicos. Uma vez resfriados à $36^{\circ} \mathrm{C}$, os copos foram armazenados em prateleiras à temperatura ambiente, até serem abertos para análises do produto final. 


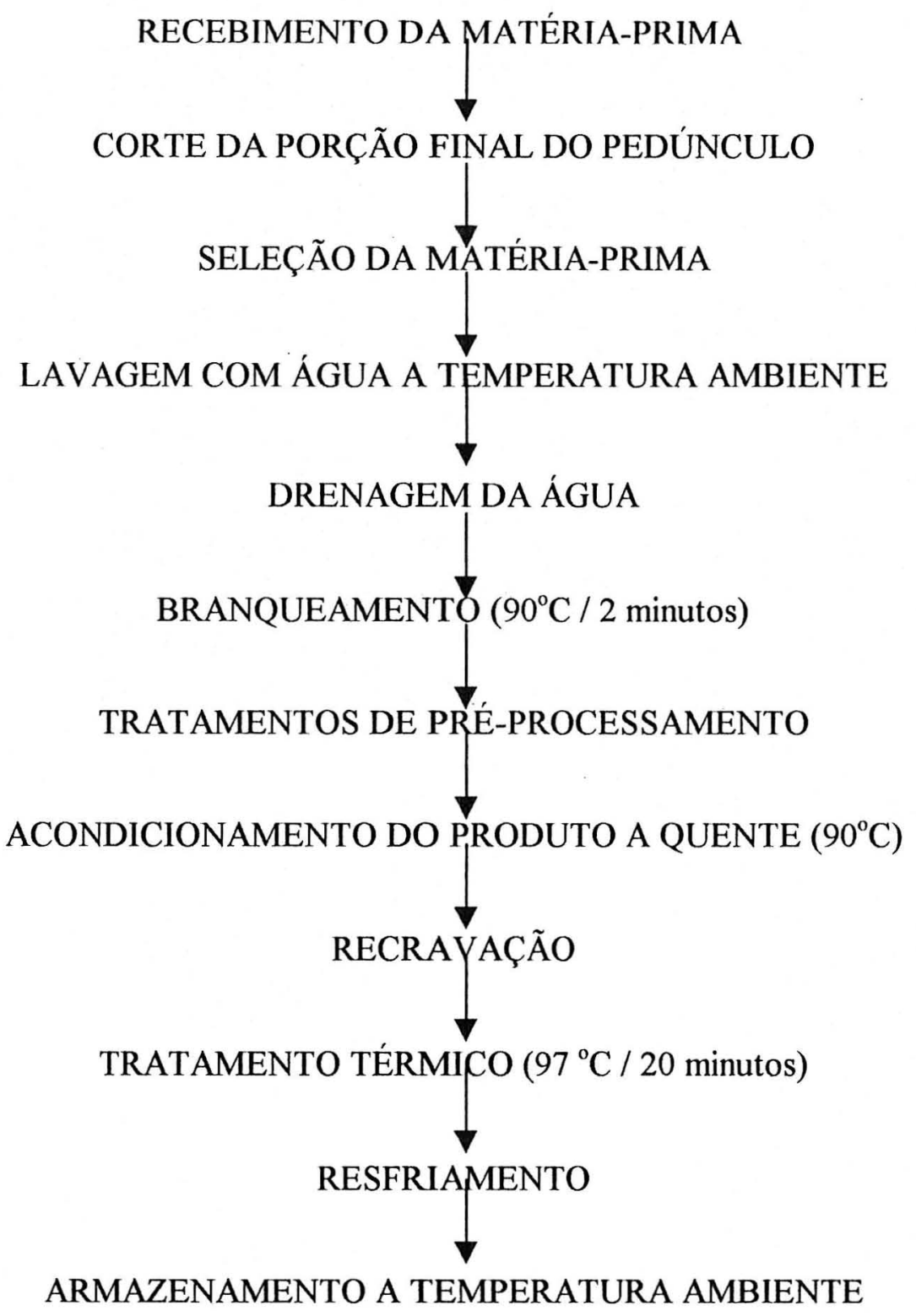

Figura 3. Fluxograma das operações utilizadas para a obtenção de cogumelos acidificados e processados termicamente. 


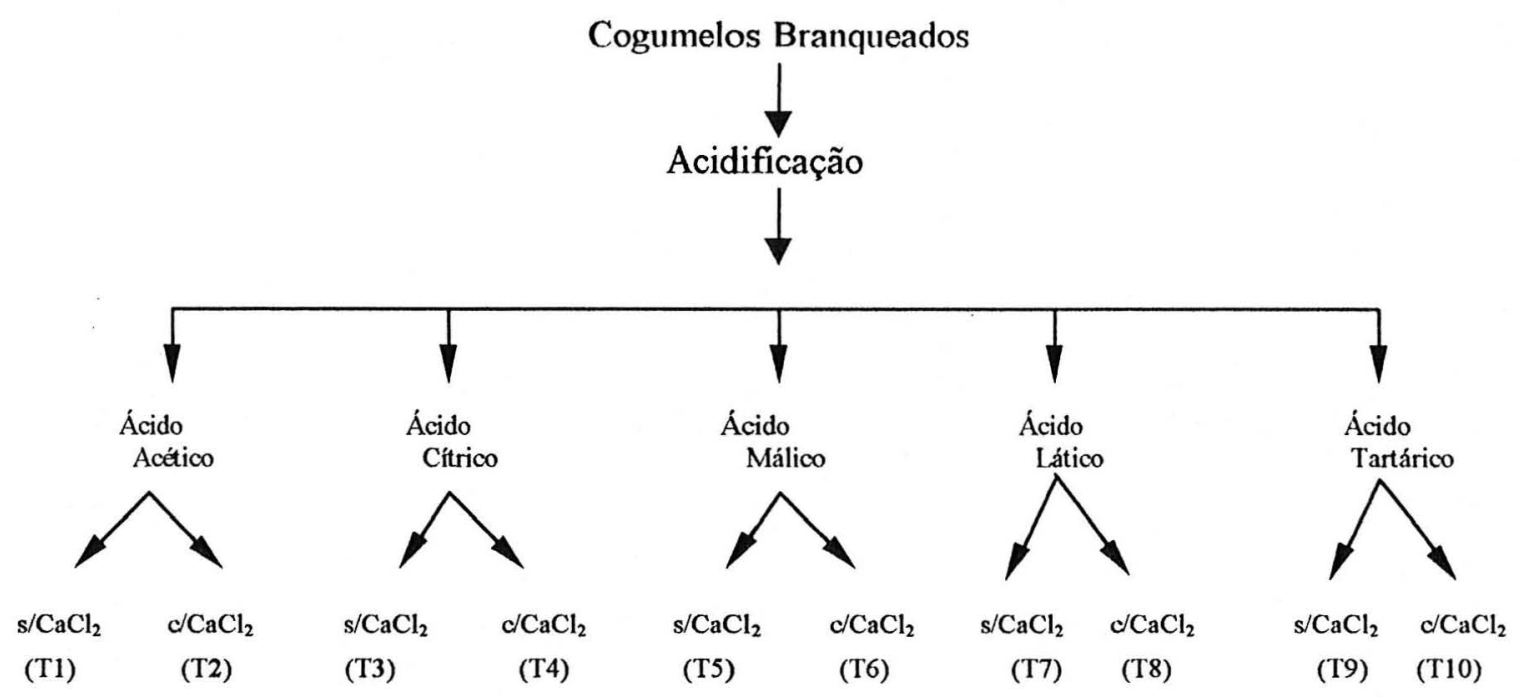

Figura 4. Esquema dos tratamentos aplicados aos cogumelos para obtenção do produto em conserva.

\subsubsection{Desidratação}

As operações utilizadas para a obtenção do produto desidratado estão indicadas na Figura 5. As operações que vão desde o recebimento da matériaprima até a drenagem da água da lavagem foram realizadas como descrito no item 4.3.1.

No que se refere à aplicação de branqueamento nos cogumelos submetidos a secagem, há controvérsias nos trabalhos da literatura encontrados. Porém, de acordo com testes preliminares realizados com a matéria-prima aqui empregada, os cogumelos não sofreram o branqueamento antes da operação de secagem.

\section{a) Tratamentos de pré-secagem}

Após a lavagem e drenagem, a matéria-prima foi dividida em quatro lotes. $\mathrm{O}$ primeiro, a testemunha, foi conduzido diretamente à estufa (que já se encontrava a $70^{\circ} \mathrm{C}$ ). $\mathrm{O}$ segundo tratamento consistiu na imersão dos cogumelos 
em sua solução de $\mathrm{CaCl}_{2}$ a $0,2 \%(\mathrm{p} / \mathrm{v})$, por 5 minutos. $\mathrm{O}$ terceiro tratamento consistiu na imersão dos cogumelos em uma solução de ácido cítrico a $0,5 \%$ (p/v), por 5 minutos. O quarto lote de matéria-prima foi imerso em uma solução com $0,5 \%$ de ácido cítrico e $0,2 \%$ de $\mathrm{CaCl}_{2}(\mathrm{p} / \mathrm{v})$, por 5 minutos. Os cogumelos foram a seguir drenados por mais 5 minutos, e conduzidos à estufa com circulação forçada de ar, a $70^{\circ} \mathrm{C}$, de acordo com resultados de testes preliminares anteriormente realizados.

Os tratamentos pré-secagem estão representados na Figura 6, e puderam ser definidos:

Tratamento 1 (T1): Testemunha

Tratamento 2 (T2): Imersão em solução de $\mathrm{CaCl}_{2}$

Tratamento 3 (T3): Imersão em solução de ácido cítrico

Tratamento 4 (T4): Imersão em solução de $\mathrm{CaCl}_{2}+$ ácido cítrico

\section{b) Secagem}

A partir do teor de umidade inicial, determinado em estufa com ventilação forçada, a $70^{\circ} \mathrm{C}$, por 24 horas, e com auxílio de uma balança semi-analítica de precisão $0,01 \mathrm{~g}$, foram determinados os teores de umidade intermediários, através de processo gravimétrico. A razão de umidade é uma variável adimensional, pois representa o peso do produto ao sair da estufa/peso do produto ao entrar na estufa.

As amostras de cogumelo, provenientes de diferentes tratamentos présecagem, foram submetidas a secagem a $70^{\circ} \mathrm{C}$, obtendo-se valores de umidade relativa de $4,2 \%$. Estes valores foram obtidos das médias de temperatura e de umidade relativa do ar ambiente, durante a execução dos testes de secagem. A oscilação das condições do ar ambiente foi, praticamente, a mesma durante os testes de secagem: a temperatura foi de 18,6 a $24,5^{\circ} \mathrm{C}$ e a umidade relativa foi de 58,9 a 73,5\%. Foi utilizado um psicrômetro para este monitoramento, e com o uso do gráfico psicrométrico, foram feitas as determinações (Puzzi, 1986). 
A secagem foi conduzida até atingir o teor de umidade de equilíbrio, o que se sucedeu 8 horas após o início do processo.

\section{c) Acondicionamento e armazenamento}

Os cogumelos desidratados foram acondicionados em copos de vidro transparentes, com tampas metálicas semi-flexíveis, recravadas pela mesmo procedimento descrito no ítem 4.3.1. O armazenamento foi realizado a temperatura ambiente, em local escuro e arejado.

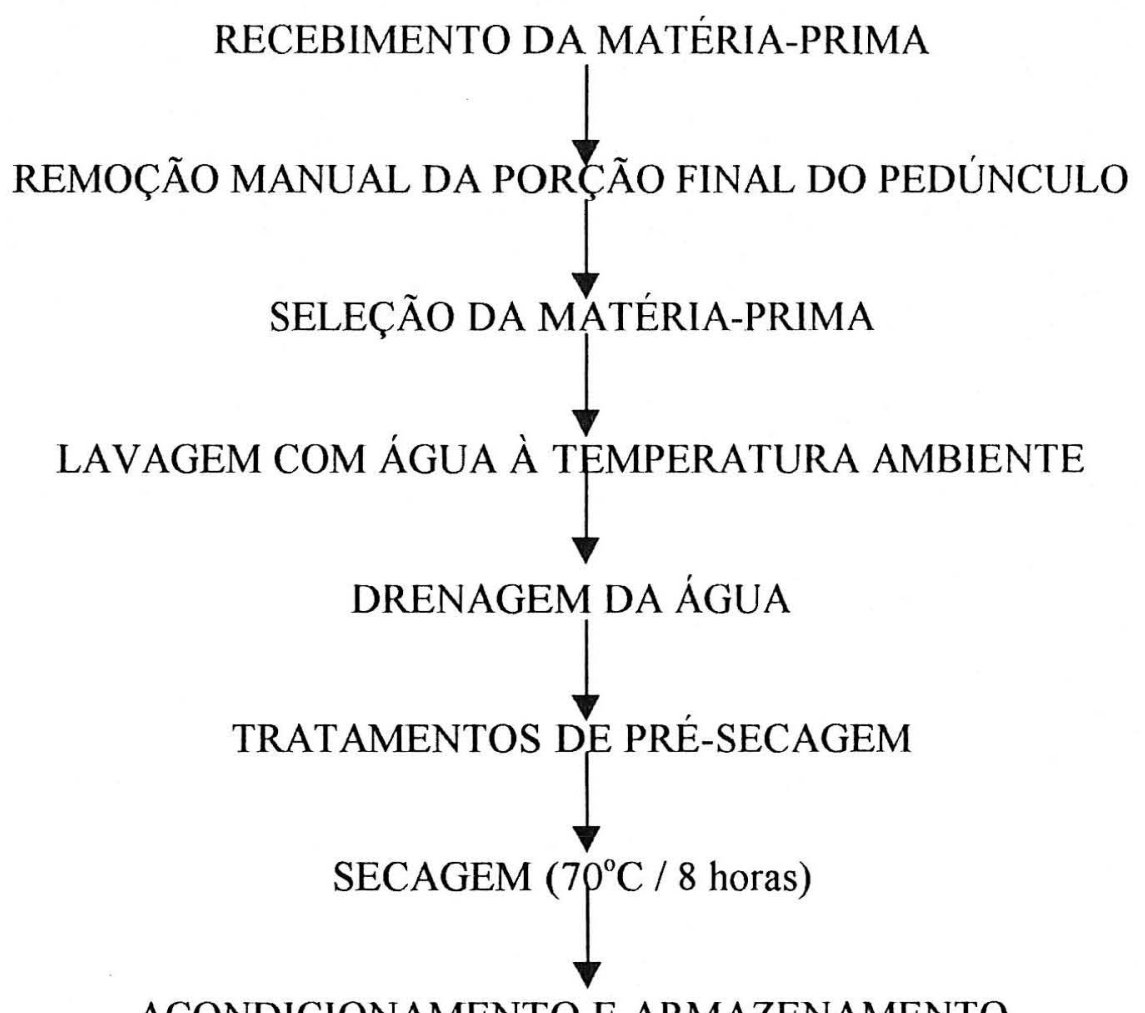

ACONDICIONAMENTO E ARMAZENAMENTO

Figura 5. Fluxograma das operações utilizadas para a obtenção de cogumelos desidratados. 
Cogumelos

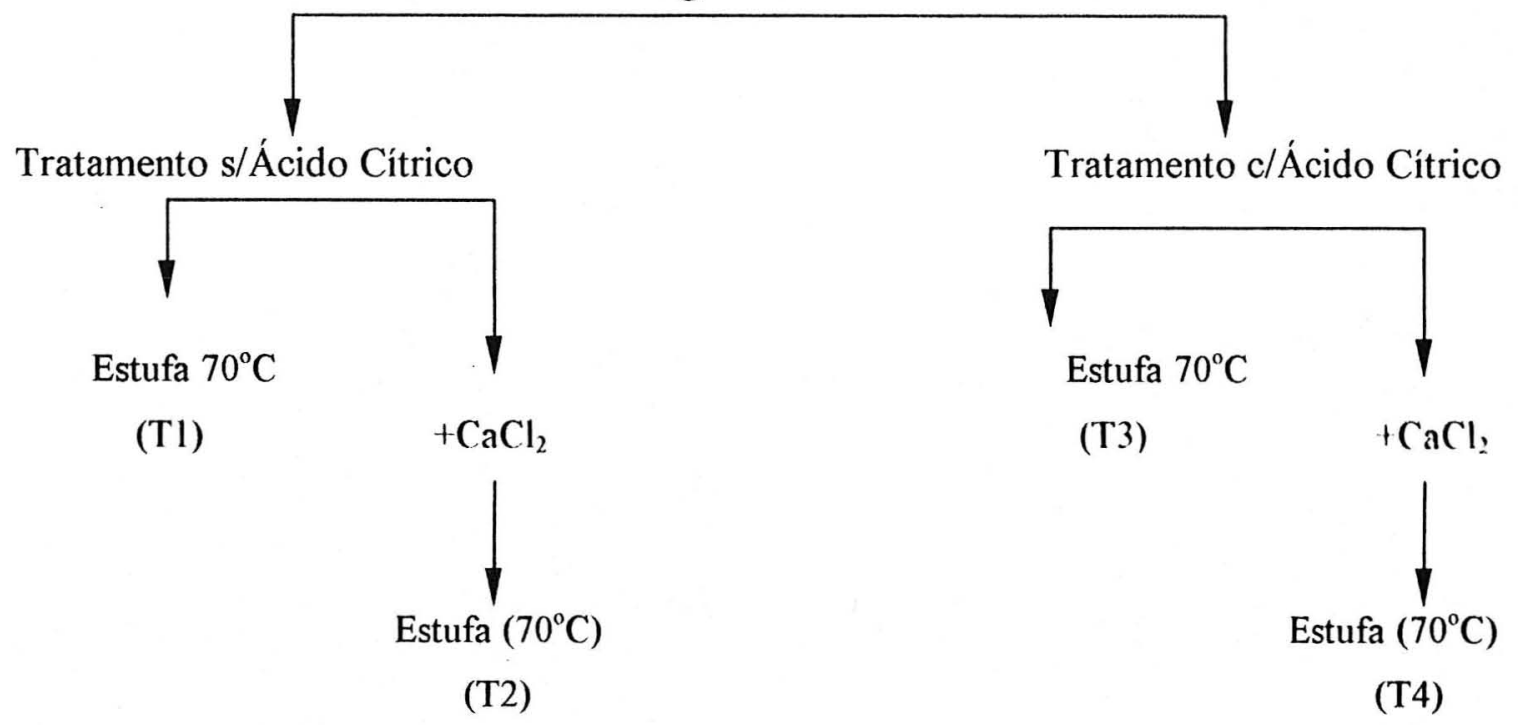

Figura 6. Esquema dos tratamentos pré-secagem aplicados aos cogumelos.

\subsection{Avaliação do Produto Final}

\subsubsection{Acidificação e Processamento Térmico}

Para avaliar a qualidade das conservas, assim como determinar a eficiência dos tratamentos aplicados e qual ácido que melhor se combinou com o sabor do produto em questão, foram realizadas análises físicas, químicas, sensoriais e microbiológicas.

As análises físicas, químicas e sensoriais foram realizadas por um período de três meses, em intervalos de 30,60 e 90 dias. As análises microbiológicas foram realizadas após 30 dias de armazenamento, pois não ocorrendo desenvolvimento microbiano nesta fase, o produto é considerado apto para consumo (esterilização comercial adequada). 


\subsubsection{Análises físicas}

a) Peso bruto: Determinado como o peso total do recipiente com todo o produto contido. O peso bruto, assim como os demais pesos, foi determinado, utilizando-se de balança semi-analítica, com precisão de $0,01 \mathrm{~g}$.

b) Peso líquido: Determinado como o peso do conteúdo do vidro, isto é, é o peso bruto menos o peso do recipiente vazio, lavado e seco.

c) Peso drenado: Determinado como o peso somente da parte sólida do produto contido no recipiente. Só pode, pois, ser determinado em produtos de duas fases (uma fase líquida e outra sólida).

Para tanto, os procedimentos realizados foram: i) inverteu-se o conteúdo do recipiente em um conjunto de peneira $\mathrm{n}^{\mathrm{o}} 8$ (malha $2,38 \mathrm{~mm}$ ) e fundo, previamente seco e tarado; ii) colocou-se a peneira ligeiramente inclinada sobre o fundo $\left(45^{\circ}\right)$; iii) deixou-se que a parte líquida fosse drenada durante 2 minutos; e, iv) pesou-se cada uma das partes do conjunto.

d) Vácuo: Determinado como a diferença entre a pressão externa (do ambiente) e a pressão interna do recipiente. A exaustão formou o vácuo, que foi medido em polegadas de mercúrio.

Para medir o vácuo, utilizou-se o vacuômetro manual "Marshalltown", depois de: i) umidecer ligeiramente a tampa do recipiente, para propiciar maior contato; ii) colocar firmemente o vacuômetro próximo da borda da tampa e comprimir, perfurando-a (nunca colocar próximo ao centro da tampa do recipiente; e, iii) ler em polegadas de mercúrio (pol. $\mathrm{Hg}$ ).

d) Textura: Determinada objetivamente como descrito no item 4.2.1. Os 
resultados da textura dos produtos acidificados/processados termicamente foram comparados com a textura do cogumelo processado termicamente, porém, não submetido à acidificação, o qual denominou-se, nos resultados obtidos, "testemunha".

f) Aspecto da salmoura: Determinada subjetivamente, a intensidade de turvação da salmoura de acondicionamento foi avaliada de acordo com a seguinte escala numérica: 1 = Sem turvação; 2 = Turvação pequena; 3 = Turvação média; $4=$ Turva; e, 5 = Turvação intensa.

Para esta avaliação visual, as salmouras estavam contidas em provetas de $250 \mathrm{ml}$, não graduadas, e foram examinadas após um repouso de 30 minutos.

4.4.1.2. Análises químicas: $\mathrm{pH}$, acidez total titulável e sólidos solúveis totais, determinados como descrito no item 4.2.2.

4.4.1.3. Análise sensorial: a qualidade da conserva de cogumelos foi avaliada subjetivamente em termos de cor, aroma, textura e sabor.

As avaliações foram realizadas por uma equipe de 8 provadores, previamente selecionados e treinados para este tipo de avaliação, utilizando-se escala numérica estruturada de 9 pontos (Girardot et al., 1953; Dawson, 1964 e Martin, 1973). Os modelos de ficha utilizados estão nas Figuras 7 e 8.

A análise sensorial foi efetuada sempre 2 horas antes ou após as refeições, períodos estes mais adequados para a realização dos testes. As avaliações foram feitas com duas repetições, de forma que cada provador avaliasse a mesma amostra duas vezes (em sessões diferentes).

Para a avaliação da cor do produto, as amostras, devidamente codificadas, foram colocadas em copos de vidro transparente, contendo a salmoura acidificada, que foram dispostos aleatoriamente em uma bancada de laboratório branca, em local com iluminação fluorescente. 
Os cogumelos são considerados ingredientes no preparo de pratos da culinária. Assim sendo, as avaliações de aroma, sabor e consistência (textura) foram feitas na forma de um produto: recheio para torta de cogumelos Pleurotus sajor-caju.

Para a avaliação do aroma, consistência e sabor do produto, as amostras foram servidas em pratos de plástico branco (diâmetro de $12 \mathrm{~cm}$ ), codificados com números aleatórios de três dígitos, e em cabines individuais iluminadas com luz vermelha, e com copos de água $(80 \mathrm{ml})$. As avaliações dos produtos processados foram feitas tendo-se, entre as amostras, uma testemunha que foi preparada da mesma forma, porém, utilizando-se cogumelos frescos.

\section{AVALIAÇÃO SENSORIAL}

Produto:

Nome do Provador: Data 11

Por favor, prove as amostras e indique a intensidade da COR, de acordo com a escala abaixo:

\begin{tabular}{|c|c|c|c|c|c|c|}
\hline Amostras & Péssimo & Ruim & Regular & $\begin{array}{l}\text { Bom } \\
788\end{array}$ & Otimo & Observações \\
\hline 119 & & & & & & \\
\hline 914 & & & & & & \\
\hline 637 & & & & & & \\
\hline 249 & & & & & & \\
\hline 337 & & & & & & \\
\hline 449 & & & & & & \\
\hline
\end{tabular}

Figura 7. Modelo de ficha utilizado na avaliação sensorial das amostras do produto quanto à cor. 


\section{AVALIAÇÃO SENSORIAL}

Produto:

Nome do Provador: Data 11

Por favor, prove as amostras e indique a intensidade do AROMA, de acordo com a escala abaixo:

\begin{tabular}{|c|c|c|c|c|c|c|}
\hline Amostras & $\begin{array}{c}\text { Péssimo } \\
1\end{array}$ & $\begin{array}{l}\text { Ruim } \\
2 \quad 3\end{array}$ & $\begin{array}{l}\text { Regular } \\
\begin{array}{lll}4 & 5 & 6\end{array}\end{array}$ & $\begin{array}{l}\text { Bom } \\
7 \quad 8\end{array}$ & $\begin{array}{c}\text { Ótimo } \\
9\end{array}$ & Observações \\
\hline 119 & & & & & & \\
\hline 914 & & & & & & \\
\hline 637 & & & & & & \\
\hline 249 & & & & & & \\
\hline 337 & & & & & & \\
\hline 449 & & & & & & \\
\hline
\end{tabular}

Por favor, prove as amostras e indique a intensidade da TEXTURA, de acordo com a escala abaixo:

\begin{tabular}{|c|c|c|c|c|c|c|}
\hline Amostras & $\begin{array}{c}\text { Péssimo } \\
1\end{array}$ & $\begin{array}{l}\text { Ruim } \\
2 \quad 3\end{array}$ & $\begin{array}{l}\text { Regular } \\
\begin{array}{lll}4 & 5 & 6\end{array}\end{array}$ & $\begin{array}{l}\text { Bom } \\
7 \quad 8 \\
\end{array}$ & $\begin{array}{c}\text { Ótimo } \\
9\end{array}$ & Observações \\
\hline 119 & & & & & & \\
\hline 914 & & & & & & \\
\hline 637 & & & & & & \\
\hline 249 & & & & & & \\
\hline 337 & & & & & & \\
\hline 449 & & & & & & \\
\hline
\end{tabular}

Por favor, prove as amostras e indique a intensidade do SABOR, de acordo com a escala abaixo:

\begin{tabular}{|c|c|c|c|c|c|c|}
\hline Amostras & $\begin{array}{c}\text { Péssimo } \\
1\end{array}$ & $\begin{array}{l}\text { Ruim } \\
23\end{array}$ & $\begin{array}{l}\text { Regular } \\
456\end{array}$ & $\begin{array}{r}\text { Bom } \\
7 \quad 8\end{array}$ & $\begin{array}{c}\text { Ótimo } \\
9\end{array}$ & Observações \\
\hline 119 & & & & & & \\
\hline 914 & & & & & & \\
\hline 637 & & & & & & \\
\hline 249 & & & & & & \\
\hline 337 & & & & & & \\
\hline 449 & & & & & & \\
\hline
\end{tabular}

Figura 8. Modelo de ficha utilizado na avaliação sensorial das amostras do produto quanto ao aroma, à textura e ao sabor. 
4.4.1.4. Análises microbiológicas: foram realizadas para cada ácido orgânico utilizado (com e sem adição de $\mathrm{CaCl}_{2}$ ), visando testar a eficiência dos tratamentos e da esterilização, de acordo com o proposto pela American Public Health Association - APHA (Corlett \& Denny, 1984).

Os produtos acidificados foram analisados especificamente quanto à atividade biológica em $\mathrm{pH} 4,3$; visando principalmente a recuperação de Bacillus coagulans e Bacillus stearothermophilus, que são as bactérias utilizadas como padrão da esterilização comercial para alimentos com pH menor que 4,6.

$\mathrm{O}$ meio de cultura utilizado foi o Plate Count Agar (PCA), recomendado para contagem microbiana total. Sob condições assépticas, procedeu-se a abertura dos vidros, a coleta das alíquotas da salmoura, o plaqueamento e a incubação. Não se coletou o próprio alimento, visto que o tempo de armazenamento (30 dias) permitiu um adequado equilíbrio com a salmoura.

Para uma averiguação mais completa do número (UFC/ml ou $\mathrm{UFC} / \mathrm{g}$ ) de possíveis microrganismos sobreviventes, foram utilizadas diluições de $10^{0}$ e $10^{-1}$, sob as condições: mesófilos - incubação a $32^{\circ} \mathrm{C} / 24-48$ horas; termófilos incubação a $50^{\circ} \mathrm{C} / 24-48$ horas; esporos - ativação a $80^{\circ} \mathrm{C} / 10$ minutos, seguida de incubação por $24-48$ horas a $32^{\circ} \mathrm{C}$ e $50^{\circ} \mathrm{C}$ para os mesófilos e termófilos, respectivamente.

Os resultados foram expressos em presença (+) ou ausência $(-)$ de atividade microbiana.

\subsubsection{Desidratação}

Para se avaliar a qualidade dos cogumelos secos, assim como determinar a eficiência dos tratamentos aplicados, foram realizadas análises físicas, químicas e sensoriais, já comentadas anteriormente, nos ítens 4.2 e 4.4 .

Para a realização das análises físicas do rendimento e textura, as análises químicas e as análises sensoriais, o produto seco foi reidratado com dez partes de 
solução $0,6 \% \mathrm{NaCl}$, por 24 horas, sob refrigeração $\left(4-6^{\circ} \mathrm{C}\right)$. A seguir, os cogumelos foram cozidos, juntamente com esta solução, por 20 minutos, sob pressão atmosférica (Jorge, 1989 e Bano \& Rajarathnam, 1989).

Todas as análises do produto final desidratado foram realizadas após 30 , 60 e 90 dias de armazenamento.

4.4.2.1. Análises físicas: Peso bruto, peso líquido, textura e rendimento, determinados como descrito nos ítens 4.2 e 4.4.1.

4.4.2.2. Análises químicas: $\mathrm{pH}$ e sólidos solúveis, determinados como descrito nos ítens 4.2 e 4.4.1.

4.4.2.3. Análise sensorial: Cor, aroma, textura e sabor, determinados como descrito no item 4.4.1.

4.4.2.4. Análise estatística: $A$ análise estatística dos resultados referentes às avaliações dos produtos finais foram realizadas empregando-se a análise de variância com utilização do teste $\mathrm{F}$ (Gomes, 1990).

Os dados dos produtos processados (acidificados/processados termicamente e desidratados) foram analisados através do delineamento em blocos casualizados. Na acidificação e processamento térmico, o delineamento se deu com 10 tratamentos e 2 repetições. Na desidratação, o delineamento se deu com 4 tratamentos e 2 repetições.

Para diferenciação das médias obtidas, foi utilizado o teste de Tukey ao nível de 5\% de significância (Moraes, 1985 e Shirose, 1985).

As médias obtidas nas avaliações sensoriais foram analisadas também por meio do delineamento em blocos casualizados (DBC), com a utilização do teste de Tukey, ao nível de $5 \%$ de significância. Cada provador foi designado como sendo um bloco. Na avaliação sensorial do produto acidificado, o delineamento se 
deu com 11 tratamentos e 2 repetições, para cada produto testado; na avaliação do produto seco, o delineamento se deu com 5 tratamentos e 2 repetições, para cada produto testado. 


\section{RESULTADOS E DISCUSSÃO}

\subsection{Caracterização da matéria-prima}

\subsubsection{Análises físicas}

A matéria-prima foi analisada aproximadamente 5 horas após sua colheita, através de amostragem simples.

Na Tabela 1, são apresentados os resultados da avaliação objetiva dos atributos físicos da matéria-prima (rendimento e textura).

Tabela 1. Características fisicas de amostras de cogumelos Pleurotus sajor-caju.

\begin{tabular}{|l|c|}
\hline Análises & Médias \\
\hline Rendimento (\%) & $92,00 \pm 0,5$ \\
Textura ( Lbf/g) & $8,20 \pm 0,2$ \\
\hline
\end{tabular}

O rendimento é um parâmetro de qualidade para a indústria de alimentos, já que reflete, quantitativamente, a qualidade da matéria-prima. 
$\mathrm{O}$ resultado do rendimento mostra que as perdas no preparo da matériaprima para o processamento (seleção e "toalete") são pequenas, indicando que o produto, quando colhido no momento certo e de maneira adequada, pode ser quase que totalmente aproveitável, pois representa uma matéria-prima de boa qualidade, praticamente isenta de cogumelos amassados, machucados ou deteriorados por microrganismos.

$O$ resultado médio encontrado para a textura $(8,2 \mathrm{Lbl} / \mathrm{g})$ pode ser considerado bastante elevado quando comparado à resultados de outros tecidos vegetais (por exemplo, a cenoura apresenta textura média de 9,50 Lbf/g; o morango tem textura próxima à $0,90 \mathrm{Lbf} / \mathrm{g}$ ), o que revela a grande resistência dos tecidos que compõe a matéria-prima em questão, ao cisalhamento.

Segundo Chitarra \& Chitarra (1990), a textura é definida como "o conjunto de propriedades do alimento, compostas por características físicas perceptíveis pelo tato e que se relacionam com a deformação, desintegração e fluxo do alimento, sob a aplicação de uma força". As sensações que caracterizam a textura de alimentos são múltiplas, na sua maioria induzidas por características mecânicas, embora também possam ser induzidas por características geométricas ou químicas. As principais sensações são de dureza, maciez, fibrosidade, suculência, granulosidade, qualidade farinácea, resistência e elasticidade.

A manutenção da textura é o maior entrave no processamento térmico de alimentos, principalmente no caso de cogumelos do gênero Pleurotus, cujas lamelas constituintes retém a solução salina acidificada em seu interior.

Chitarra \& Chitarra (1990) afirmam que frutos e hortaliças destinados ao processamento, devem ser firmes o suficiente para suportarem os tratamentos térmicos, estando a firmeza diretamente correlacionada ao tipo e conteúdo de pectina presentes. As substâncias pécticas são os principais componentes químicos dos tecidos, responsáveis pelas mudanças de textura. 
A afirmação acima refere-se à frutas e hortaliças, porém, a matéria-prima em questão é um fungo; e em uma tentativa de extrapolação, convém ressaltar que cogumelos comestiveis, que são indivíduos procariotos, contém apenas cerca de $3,7 \%$ de substâncias pécticas (precursoras da pectina) em sua composição química, segundo estudos de Bano \& Rajarathnam (1988). O principal componente estrutural da parede celular do cogumelo é a quitina, que é um polímero de $\mathrm{N}$-acetilglucosamina, considerado o maior constituinte do conteudo em fibra de cogumelo.

Portanto, é importante ressaltar que embora as considerações acima sobre a firmeza dos produtos alimentares destinados ao processamento térmico, continuem sendo de extrema valia, no caso dos cogumelos em questão, não é a pectina a substância responsável pela manutenção da textura nos produtos elaborados, e sim a quitina e os outros constituintes celulares da fração de carboidratos.

De acordo com Bano \& Rajarathnam (1988) os carboidratos representam o maior constituinte das espécies de Pleurotus, variando de 46,6 a 81,8\% da matéria-seca. Os carboidratos solúveis representam $4,2 \%$, as pentosanas representam $1,7 \%$ e $32,3 \%$ são hexonas da base seca. Entre os carboidratos poliméricos estão o glicogênio (utilizado para estocagem de energia e presente em uma proporção de 8,9\%) e a quitina. Crisan \& Sands (1978) já afirmavam em seus estudos que é o nitrogênio da quitina que contribui para o alto teor de proteína normalmente determinado por análises padrões que empregam o fator de conversão $6,25 \mathrm{xN}$.

Estudos realizados por Kurasawa et al. (1982) sobre o conteúdo de fibra em Pleurotus sajor-caju obtiveram como resultados médios em base seca: 11,6\% de celulose, 27,8\% de hemicelulose, 6,1\% de lignina, 2,0\% de substâncias pécticas, $8,0 \%$ de fibra bruta e um total de fibra dietética de $47,5 \%$. 


\subsubsection{Análises químicas}

A matéria-prima foi analisada em seus atributos químicos $(\mathrm{pH}$, acidez total titulável e sólidos solúveis totais), e os resultados obtidos estão na Tabela 2.

Tabela 2. Características químicas de amostras de cogumelos Pleurotus sajorcaju.

\begin{tabular}{|l|c|}
\hline Análises & Médias \\
\hline $\mathrm{pH}$ & $6,00 \pm 0,1$ \\
Acidez Titulável (g ácido/100g produto) & $0,04 \pm 0,002$ \\
Sólidos Solúveis Totais $\left({ }^{\circ}\right.$ Brix) & $6,00 \pm 0,5$ \\
\hline
\end{tabular}

De acordo com Chitarra \& Chitarra (1990), os ácidos encontram-se dissolvidos nos vacúolos das células, tanto na forma livre, como na forma de sais, ésteres, e outros compostos. Em alimentos, não só contribuem para a acidez, como também para o aroma característico, porque alguns componentes são voláteis.

Dentre as análises químicas realizadas neste trabalho, o $\mathrm{pH}$ da matériaprima merece atenção especial, uma vez que se objetivou reduzi-lo ao valor 4,3 , valor este considerado padrão para produtos acidificados garantirem que 0 Clostridium botulinum não se desenvolva.

O teor de ácidos orgânicos diminui com a maturação, em decorrência do processo respiratório ou de sua conversão em açúcares. Os compostos ácidos são 
numerosos e possuem natureza química variada. Dentre eles, os mais abundantes nos vegetais, em geral, são o cítrico e o málico, havendo predominância desses ou de outros, de acordo com a espécie considerada. No caso da espécie Pleurotus sajor-caju, a acidez foi expressa em gramas de ácido cítrico/100g do cogumelo, por ser o ácido cítrico predominante dentre os demais.

Os valores de $\mathrm{pH}$ encontrados $(6,00)$ são inferiores às médias encontradas por Bano \& Rajarathnam (1989): 6,10 - 6,40. Os valores de acidez total foram semelhantes aos encontrados por estes autores.

Os sólidos solúveis totais têm tendência de aumento com a maturação, através de processos de biossíntese ou pela degradação de polissacarídios. Este parâmetro químico representa uma das melhores formas de avaliação do teor de açúcares do produto, já que o teor de açúcares normalmente constitui 65 a $85 \%$ do teor de sólidos solúveis totais (Chitarra \& Chitarra, 1990).

Os teores de sólidos solúveis totais encontrados $(6,00)$ são deveras inferiores aos encontrados por Bano \& Rajarathnam (1988), que foram próximos a 7,50, o que leva a concluir que os corpos de frutificação utilizados pelos pesquisadores estavam em estágio de maturação mais avançado que os utilizados nesta pesquisa.

\subsubsection{Curvas de acidificação}

As curvas de acidificação utilizadas para determinar a quantidade de ácido necessária para abaixar o pH dos cogumelos de 6,0 para 4,3, de acordo com o ácido utilizado (acético, cítrico, málico, lático ou tartárico), estão na Figura 9. A metodologia empregada para a determinação das curvas de acidificação, também designadas curvas de titulação, foi descrita por Bernhardt (1989). 
$\rightarrow-1-2-2-3 \rightarrow-4-x-5$

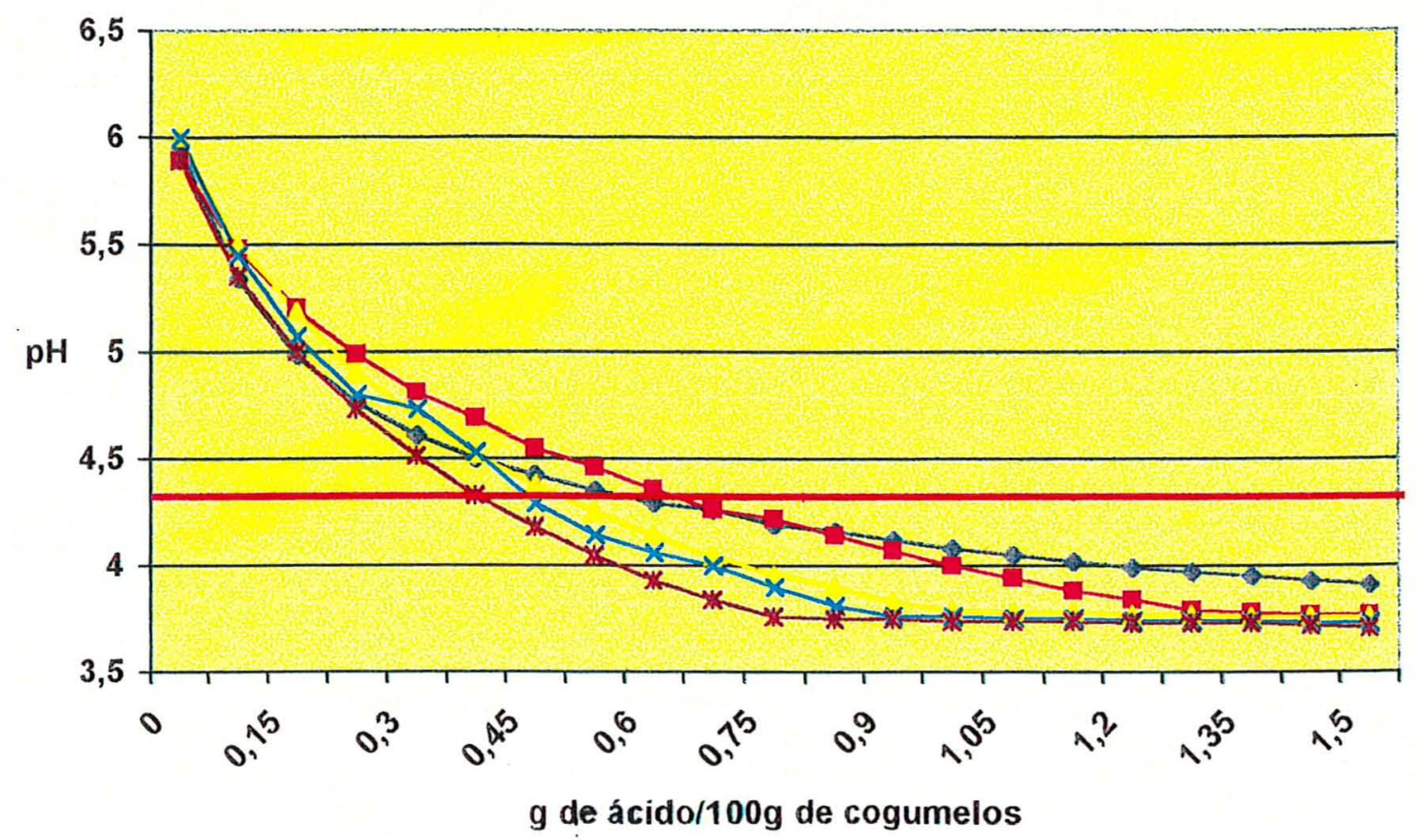

Figura 9. Curvas de acidificação de cogumelos da espécie Pleurotus sajor-caju, com cinco ácidos orgânicos, visando $\mathrm{pH}$ 4,3. (1 - Ácido acético = 0,65 g; 2 - Ácido cítrico $=0,63 ; 3$ - Ácido málico $=0,50 \mathrm{~g} ; 4$ - Ácido lático $=$ $0,42 \mathrm{~g} ; 5$ - Ácido tartárico = 0,38 g).

As variações entre os ácidos ocorrem, devido à constante de dissociação de cada ácido e ao "efeito tampão" do produto analisado (Bernhardt, 1989).

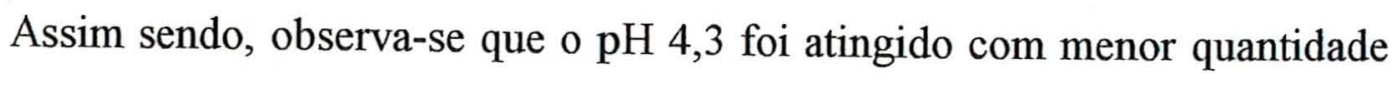
de ácido tartárico, e maior quantidade de ácido acético. Em uma escala decrescente de quantidade de ácido necessária para $\mathrm{pH}$ 4,3, temos: ácido acético, ácido cítrico, ácido málico, ácido lático e ácido tartárico. 
Os resultados aqui encontrados confirmam a escala proposta por Nogueira et al. (1994), em pesquisa realizada com cenoura, na qual a ordem da necessidade de ácido para pH 4,3 de equilíbrio, foi a mesma encontrada neste trabalho.

Convém ressaltar que cabe ao interessado em uma indústria, por exemplo, avaliar a relação custo-benefício dos ácidos envolvidos (preço, quantidade necessária, vantagens no produto final, dentre outros fatores), a fim de se tomar decisões sobre qual ácido deverá ser utilizado para o seu produto.

\subsection{Caracterização do produto acidificado e processado termicamente}

\subsubsection{Análises físicas}

O parâmetro "peso bruto" é importante para a indústria para fins de armazenamento e transporte, principalmente. No entanto, nunca aparece nos rótulos de produtos, pois não é de interesse do consumidor final.

Os valores médios de peso bruto dos recipientes com o produto final elaborado (Tabela 3) não apresentaram diferenças significativas em relação aos tratamentos, bem como em função do tempo de armazenamento.

$\mathrm{O}$ peso médio do recipiente de vidro (a tara média) no qual foram armazenados os cogumelos processados era de 173,0 $\pm 2,5 \mathrm{~g}$, assim distribuídos: $170,0 \pm 2,5$ g correspondentes ao copo de vidro vazio, lavado e seco, e 3,1 $\pm 0,3$ g correspondentes à tampa metálica responsável pelo fechamento do produto. 
Tabela 3. Valores médios do peso bruto $(\mathrm{g})$ dos recipientes dos cogumelos processados termicamente, em função do tempo de armazenamento.

\begin{tabular}{|c|c|c|c|c|c|c|c|c|c|c|c|}
\hline \multirow{3}{*}{$\begin{array}{c}\text { Tempo } \\
\text { (dias) }\end{array}$} & \multicolumn{10}{|c|}{ Tratamentos ácidos } & \multirow{3}{*}{ Médias } \\
\hline & \multicolumn{2}{|c|}{ Acético } & \multicolumn{2}{|c|}{ Cítrico } & \multicolumn{2}{|c|}{ Málico } & \multicolumn{2}{|c|}{ Lático } & \multicolumn{2}{|c|}{ Tartárico } & \\
\hline & I & II & $\mathrm{I}$ & II & I & II & I & II & I & II & \\
\hline 0 & 423,5 & 420,7 & 424,8 & 425,0 & 425,1 & 422,0 & 422,9 & 423,5 & 424,8 & 425,1 & $423,7^{\mathrm{A}}$ \\
\hline 30 & 422,3 & 423,5 & 420,2 & 421,8 & 420,6 & 419,9 & 423.8 & 425,0 & 420,9 & $+19,9$ & $+21.5^{A}$ \\
\hline 60) & 423,5 & 421,0 & 425,9 & 423,4 & 421,5 & 420,5 & 424,6 & 423,9 & 422,1 & 419,6 & $422,8^{A}$ \\
\hline 90 & 420,9 & 422,8 & 419,9 & 420,9 & 422,8 & 423,1 & 423,8 & 421,0 & 421,8 & 425,4 & $421,1^{\mathrm{A}}$ \\
\hline Médias & $422,5^{\mathrm{A}}$ & $422,0^{\mathrm{A}}$ & $422,7^{A}$ & $422,8^{\AA}$ & $422,5^{\mathrm{A}}$ & $421,4^{\mathrm{A}}$ & $423,7^{A}$ & $423,3^{\mathrm{A}}$ & $422,4^{\mathrm{A}}$ & $422,5^{\mathrm{A}}$ & - \\
\hline F (Trat.) & \multicolumn{10}{|c|}{2,35 n.s. } & - \\
\hline $\mathrm{F}$ (tempo) & \multicolumn{10}{|c|}{2,17 n.s. } & - \\
\hline
\end{tabular}

$\mathrm{I}$ = sem cálcio; $\mathrm{II}$ = com cálcio

n.s. = não significativo pelo teste de Tukey.

Médias com a mesma letra não diferem entre si ao nível de 5\% de significância.

Os pesos líquido e drenado são parâmetros importantes para o consumidor, pois referem-se ao conteúdo do recipiente, ao produto em si; portanto, aparecem nos rótulos das embalagens de alimentos.

Os pesos médios líquido e drenado da conserva de cogumelos Pleurotus sajor-caju (Tabelas 4 e 5) também não apresentaram diferenças estatísticas significativas entre os diferentes tratamentos e ao longo do período de armazenamento. Estas análises demonstraram que o preenchimento dos copos foi feito de maneira adequada, obtendo-se assim, produtos com pesos semelhantes, fato este, altamente desejável em qualquer tipo de processamento de alimentos, já que o peso é um dos importantes fatores no controle de qualidade. 
Tabela 4. Valores médios do peso líquido (g) dos recipientes dos cogumelos processados termicamente, em função do tempo de armazenamento.

\begin{tabular}{|c|c|c|c|c|c|c|c|c|c|c|c|}
\hline \multirow{3}{*}{$\begin{array}{l}\text { Tempo } \\
\text { (dias) }\end{array}$} & \multicolumn{10}{|c|}{ Tratamentos ácidos } & \multirow{3}{*}{ Médias } \\
\hline & \multicolumn{2}{|c|}{ Acético } & \multicolumn{2}{|c|}{ Cítrico } & \multicolumn{2}{|c|}{ Málico } & \multicolumn{2}{|c|}{ Lático } & \multicolumn{2}{|c|}{ Tartárico } & \\
\hline & I & II & I & II & I & II & I & II & I & II & \\
\hline 0 & 250,5 & 246,9 & 248,6 & 251,1 & 247,7 & 251,5 & 250,5 & 249,8 & 246,9 & 250,9 & $249,4^{\mathrm{A}}$ \\
\hline 30 & 248,5 & 250,5 & 251,6 & 248.4 & 251,1 & 250.5 & $249,()$ & 247.1 & 249.9 & 25()$, 9$ & $250.1^{A}$ \\
\hline 60 & 250,0 & 251,9 & 250,7 & 249,3 & 249,4 & 247,1 & 247,5 & 249,1 & 251,1 & 251,9 & $251,1^{\mathrm{A}}$ \\
\hline 90 & 251,1 & 251,7 & 251,6 & 247,9 & 248,2 & 247,0 & 251,5 & 248,6 & 250,8 & 248,8 & $249,9^{\mathrm{A}}$ \\
\hline Médias & $250,1^{A}$ & $251,2^{\mathrm{A}}$ & $250,9^{\mathrm{A}}$ & $249,3^{\mathrm{A}}$ & $249,5^{\mathrm{A}}$ & $247,3^{A}$ & $250,0^{\mathrm{A}}$ & $249,4^{\mathrm{A}}$ & $249,9^{A}$ & $251,1^{\mathrm{A}}$ & - \\
\hline F (Trat.) & & & & & 22,1 & n.s. & & & & & - \\
\hline $\mathrm{F}$ (tempo) & & & & & 2,0 & n.s. & & & & & - \\
\hline
\end{tabular}

I = sem cálcio; $\mathrm{II}=$ com cálcio

n.s. = não significativo pelo teste de Tukey.

Médias com a mesma letra não diferem entre si ao nível de $5 \%$ de significância.

Tabela 5. Valores médios do peso drenado (g) dos recipientes dos cogumelos processados termicamente, em função do tempo de armazenamento.

\begin{tabular}{|c|c|c|c|c|c|c|c|c|c|c|c|}
\hline \multirow{3}{*}{$\begin{array}{l}\text { Tempo } \\
\text { (dias) }\end{array}$} & \multicolumn{10}{|c|}{ Tratamentos ácidos } & \multirow{3}{*}{ Médias } \\
\hline & \multicolumn{2}{|c|}{ Acético } & \multicolumn{2}{|c|}{ Cítrico } & \multicolumn{2}{|c|}{ Málico } & \multicolumn{2}{|c|}{ Lático } & \multicolumn{2}{|c|}{ Tartárico } & \\
\hline & I & II & I & II & I & II & I & II & I & II & \\
\hline 0 & 150,8 & 152,9 & 150,7 & 151,8 & 152,5 & 150,8 & 150,6 & 152,8 & 151,9 & 152,1 & $151,9^{\mathrm{A}}$ \\
\hline 30 & 153,7 & 154,1 & 152,2 & 153,7 & 152,6 & 152,4 & 153,9 & 154,1 & 151,8 & 151,9 & $153,6^{\mathrm{A}}$ \\
\hline 60 & 154,7 & 155,9 & 155,5 & 157,1 & 153,1 & 157,1 & 154,7 & 154,9 & 154,8 & 150,1 & $154,1^{\mathrm{A}}$ \\
\hline 90 & 153,9 & 155,8 & 157,8 & 153,0 & 154,8 & 155,0 & 152,9 & 153,2 & 153,7 & 151,2 & $153,1^{\mathrm{A}}$ \\
\hline Médias & $153,7^{\mathrm{A}}$ & $155,7^{\mathrm{A}}$ & $155,5^{\mathrm{A}}$ & $153,6^{\mathrm{A}}$ & $153,1^{A}$ & $154,3^{\mathrm{A}}$ & $154,8^{\AA}$ & $154,5^{\bar{A}}$ & $153,0^{\wedge}$ & $151,8^{\mathrm{A}}$ & - \\
\hline F (Trat.) & \multicolumn{10}{|c|}{1,35 n.s. } & - \\
\hline $\mathrm{F}$ (tempo) & \multicolumn{10}{|c|}{$0,98 \mathrm{n} . \mathrm{s}}$. & - \\
\hline
\end{tabular}

I = sem cálcio; $\mathrm{II}$ = com cálcio

n.s. $=$ não significativo pelo teste de Tukey.

Médias com a mesma letra não diferem entre si ao nível de $5 \%$ de significância. 
Os valores médios de vácuo dos copos das conservas elaboradas (Tabela 6) não apresentaram diferenças estatísticas significativas em relação aos tratamentos, bem como em função do tempo de armazenamento considerado.

O limite mínimo de vácuo estabelecido comercialmente é de 10 pol. $\mathrm{Hg}$, caso contrário, há o risco de oxidação do produto devido ao vácuo mal formado. Portanto, os valores médios de vácuo encontrados estão dentro da faixa considerada normal, em um recipiente de produto acidificado, que deve ser maior ou igual à 10 pol. Hg. De acordo com Martin et al. (1965/66), o vácuo é dependente das operações de exaustão e da temperatura do produto na operação de fechamento dos recipientes. Assim sendo, pode-se dizer que a operação de recravação dos copos foi feita de maneira adequada, evitando-se o efeito prejudicial das reações oxidativas, as quais resultam em escurecimento e alterações organolépticas do produto.

$\mathrm{O}$ vácuo, mesmo sendo dependente do processamento, mostrou variações que puderam ser atribuídas como decorrentes da operação de recravação, da uniformidade da superficie de contato entre a tampa e a borda dos copos, ou ainda ao espaço-livre (este último sendo também dependente do volume da salmoura adicionada). Os valores de vácuo, encontrados após o período considerado máximo de estocagem (90 dias), foram considerados ótimos para a conservação do produto final (o valor mínimo foi de 11,5 polegadas de mercúrio).

Frequentemente, o oxigênio dissolvido no produto e/ou presente no espaço-livre, já é suficiente para desencadear as reações de oxidação, não bastando apenas a barreira da embalagem ao oxigênio. Logo, a desaeração do produto e o emprego de técnicas que reduzam o espaço-livre ou que diminuam a concentração de oxigênio no espaço-livre irão contribuir decididamente para o aumento da vida útil dos produtos em conserva (Catalá, 1980; Fernandes, 1982).

O espaço-livre foi determinado diretamente nos copos abertos, com uma "Régua de Espaço-Livre", que foi abaixada até que sua extremidade tocasse a 
superfície da fase líquida. Com a lingueta fixada nesta posição foi feita a leitura em milímetros, e os resultados encontrados foram, em média $7,1 \pm 0,9 \mathrm{~mm}$.

Tabela 6. Valores médios do vácuo (pol. $\mathrm{Hg}$ ) dos recipientes dos cogumelos processados termicamente, em função do tempo de armazenamento.

\begin{tabular}{|c|c|c|c|c|c|c|c|c|c|c|c|}
\hline \multirow{3}{*}{$\begin{array}{l}\text { Tempo } \\
\text { (dias) }\end{array}$} & \multicolumn{10}{|c|}{ Tratamentos ácidos } & \multirow{3}{*}{ Médias } \\
\hline & \multicolumn{2}{|c|}{ Acético } & \multicolumn{2}{|c|}{ Cítrico } & \multicolumn{2}{|c|}{ Málico } & \multicolumn{2}{|c|}{ Lático } & \multicolumn{2}{|c|}{ Tartárico } & \\
\hline & I & II & I & II & I & II & I & II & I & II & \\
\hline 0 & 12,50 & 12,50 & 12,75 & 13,75 & 12,75 & 12,50 & 14,25 & 12,25 & 13,00 & 13,50 & $13,00^{\mathrm{A}}$ \\
\hline 30 & 13,50 & 11,50 & 12,75 & 12,95 & 14,00 & 13,00 & 12,00 & 12,25 & 13,75 & 12,00 & $12,75^{\mathrm{A}}$ \\
\hline 60 & 14,25 & 12,25 & 13,25 & 12,75 & 13,12 & 11,75 & 12,50 & 12,50 & 12,00 & 13,00 & $12,45^{\mathrm{A}}$ \\
\hline 90 & 12,00 & 12,50 & 11,75 & 12,75 & 12,25 & 11,50 & 12,25 & 12,00 & 11,50 & 12,50 & $12,44^{\mathrm{A}}$ \\
\hline Médias & $13,06^{\mathrm{A}}$ & $12,19^{A}$ & $12,63^{A}$ & $13,04^{A}$ & $13,03^{A}$ & $12,19^{\mathrm{A}}$ & $12,74^{\mathrm{A}}$ & $12,25^{A}$ & $12,56^{\mathrm{A}}$ & $12,75^{\mathrm{A}}$ & - \\
\hline F (Trat.) & \multicolumn{10}{|c|}{ 2,37 n.s. } & - \\
\hline F (tempo) & \multicolumn{10}{|c|}{2,02 n.s. } & - \\
\hline
\end{tabular}

I = sem cálcio; II = com cálcio

n.s. = não significativo pelo teste de Tukey.

Médias com a mesma letra não diferem entre si ao nível de $5 \%$ de significância.

$\mathrm{Na}$ Tabela 7 são apresentados os resultados da avaliação objetiva da textura dos cogumelos Pleurotus sajor-caju acidificados e processados termicamente.

Chitarra \& Chitarra (1990) afirmam que frutas e hortaliças destinadas ao processamento, devem ser firmes o suficiente para suportarem os tratamentos térmicos, estando a firmeza diretamente correlacionada ao conteúdo e tipo de pectina presentes. As substâncias pécticas são os principais componentes químicos dos tecidos vegetais, responsáveis pelas mudanças de textura.

Porém, em células fúngicas, ou seja, nos corpos de frutificação de cogumelos comestíveis, o principal componente químico responsável pelas 
mudanças de textura, não é a pectina, visto que ela é inexistente em organismos procariotos (Nichols, 1985).

A textura é o parâmetro que merece atenção especial no caso de produtos processados termicamente, uma vez que as alterações verificadas em seus valores finais (resultados das análises do produto acabado) são deveras consideráveis. A textura dos cogumelos "in natura" apresenta valores maiores que àqueles termicamente processados, independentemente do tratamento utilizado. Concluise, pois, que a textura sempre diminui drasticamente com o emprego de tratamentos pelo uso do calor. Por outro lado, o emprego da acidificação é um recurso que pode contribuir para a manutenção da firmeza dos tecidos. Os valores de textura encontrados para os cogumelos acidificados foram sempre superiores aos valores de textura da testemunha (processada termicamente, porém não acidificada), comprovando os resultados encontrados, por exemplo, por Nogueira et al. (1994 e 1997), na acidificação de cenoura e couve-flor.

$\mathrm{O}$ cálcio tem sido usado em muitas pesquisas com frutas e hortaliças processadas termicamente, visando preservar, ao máximo, a firmeza da textura (Van Buren, 1979; Fenjim He et al., 1989; Meurer \& Gierschner, 1992).

O cálcio é um agente de retenção de sais (Van Buren, 1979 e Saldana \& Meyer, 1981). Os resultados obtidos indicam que realmente houve diferença estatisticamente significativa na textura entre os tratamentos com e sem cálcio. Porém, não houve diferença significativa na textura entre os diferentes tratamentos ácidos. 
Tabela 7. Valores médios da textura (Lbf/g) dos cogumelos processados termicamente, em função do tempo de armazenamento.

\begin{tabular}{|c|c|c|c|c|c|c|c|c|c|c|c|}
\hline \multirow{3}{*}{$\begin{array}{l}\text { Tempo } \\
\text { (dias) }\end{array}$} & \multicolumn{10}{|c|}{ Tratamentos ácidos } & \multirow{3}{*}{ Médias } \\
\hline & \multicolumn{2}{|c|}{ Acético } & \multicolumn{2}{|c|}{ Cítrico } & \multicolumn{2}{|c|}{ Málico } & \multicolumn{2}{|c|}{ Lático } & \multicolumn{2}{|c|}{ Tartárico } & \\
\hline & I & II & I & II & I & II & I & II & I & II & \\
\hline 0 & 2,33 & 3,39 & 2,31 & 3,44 & 2,35 & 3,02 & 2,13 & 3,07 & 2,23 & 3,52 & $2,85^{\mathrm{A}}$ \\
\hline 30 & 2,29 & 3,91 & 2,19 & 3,299 & 2,28 & 3,37 & 2,30 & 3,12 & 2,49 & 3,61 & $3.00^{\mathrm{A}}$ \\
\hline 60 & 2,27 & 3,45 & 2,15 & 3,55 & 2,26 & 3,81 & 2.4() & 3,30 & $2,(0)$ & 3.23 & $2.97^{\wedge}$ \\
\hline 90 & 2,23 & 2,90 & 2,10 & 3,50 & 2,10 & 3,30 & 2,33 & 3,25 & 2,11 & 3,19 & $2,90^{\mathrm{A}}$ \\
\hline Médias & $2,28^{\mathrm{B}}$ & $3,41^{C}$ & $2,20^{\mathrm{B}}$ & $3,45^{\mathrm{C}}$ & $2,26^{\mathrm{B}}$ & $3,39^{\mathrm{C}}$ & $2,30^{\mathrm{B}}$ & $3,19^{\mathrm{C}}$ & $2,24^{\mathrm{B}}$ & $3,39^{\mathrm{C}}$ & - \\
\hline F (Trat.) & \multicolumn{10}{|c|}{$56,63 * *$} & - \\
\hline F (tempo) & \multicolumn{10}{|c|}{ 2,37 n.s. } & - \\
\hline
\end{tabular}

I = sem cálcio; $\mathrm{II}=$ com cálcio

n.s. = não significativo pelo teste de Tukey.

** significativo ao nível de $5 \%$.

Médias com a mesma letra não diferem entre si ao nível de $5 \%$ de significância.

Em suma, a textura é sempre prejudicada, e no caso do Pleurotus sajorcaju em questão, o objetivo do trabalho foi preservá-la, por meio da adição do cálcio, além do tratamento ácido empregado.

No caso dos cogumelos, há evidências na literatura de que a quitina, importante constituinte dos corpos de frutificação de Pleurotus sp. possa estar envolvida em processos de mudança de textura, durante o processamento. É a quitina quem forma o "esqueleto estrutural" dos corpos de frutificação, juntamente com alguns carboidratos importantes como a celulose e hemi-celulose (Sturion, 1994).

Pela Figura 10, pode-se observar o efeito da adição de cálcio na textura dos cogumelos acidificados. Os valores assinalados no gráfico, representam a média nos três períodos de armazenamento, visto que não ocorreram variações significativas na textura, ao longo do período de armazenamento. 
$O$ resultado de textura obtido para a testemunha foi de $0,81 \mathrm{Lbf} / \mathrm{g}$, indicando que o emprego dos ácidos orgânicos, por si só, contribuiu significativamente para a manutenção da textura durante o processamento térmico. A adição do cloreto de cálcio contribuiu, ainda mais, para os resultados de textura maiores.

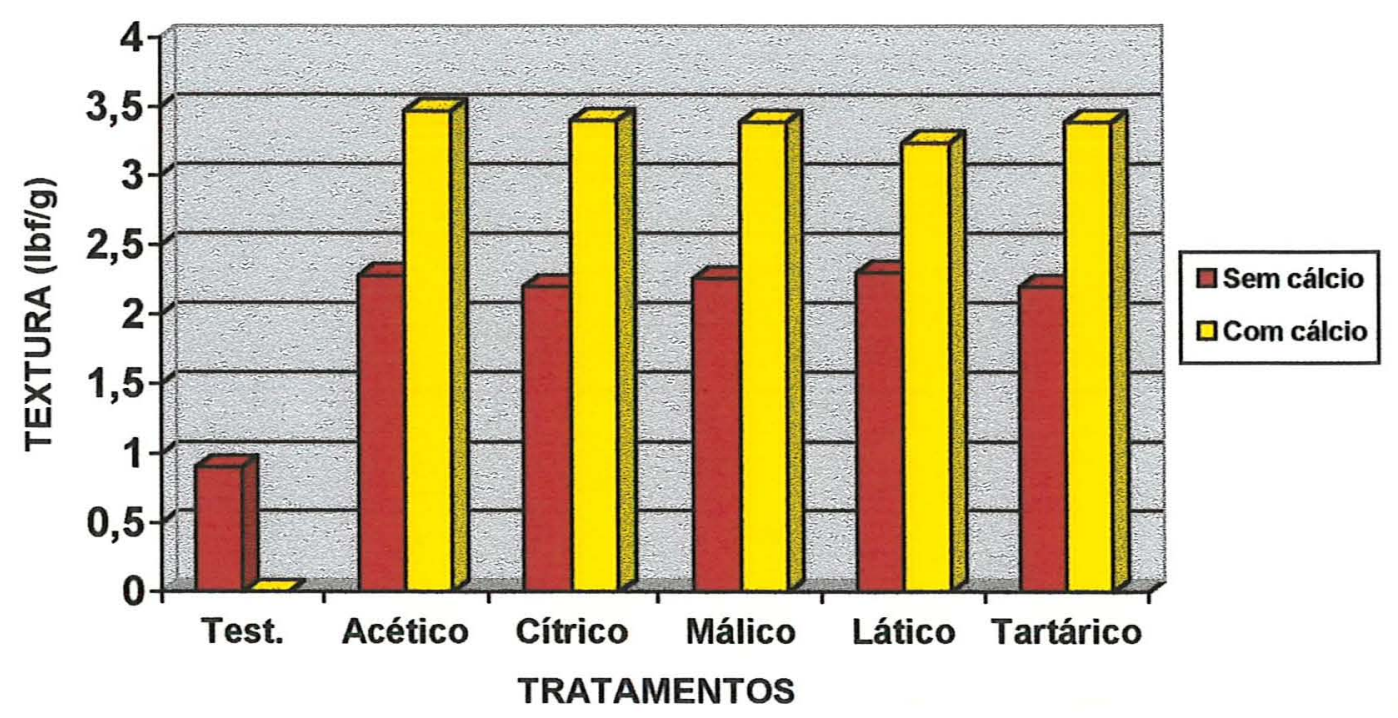

Figura 10. Efeito da adição de cálcio na textura de cogumelos processados termicamente.

Em relação ao aspecto da salmoura, não se observou qualquer turvação que pudesse prejudicar o produto e afetar sua aceitação pelo consumidor. No entanto, as salmouras que continham cloreto de cálcio eram visivelmente mais translúcidas que àquelas unicamente acidificadas. Assim sendo, de acordo com a escala utilizada para tal análise, as salmouras adicionadas de cálcio receberam pontuação 
média de 1, e as salmouras que não continham cálcio, receberam pontuação de 2 a 3, que equivalem respectivamente á pequena e média turvação. É importante finalizar, ressaltando que as pontuações 2 e 3 somente foram verificadas aos 90 dias de armazenamento, portanto o caráter turvo da salmoura não adicionada de cloreto de cálcio, somente foi evidenciado ao final das análises.

Estes resultados sugerem que o cálcio agiu eficazmente como agente de retenção de sólidos, modificando o aspecto da salmoura de enchimento dos recipientes em questão, durante o armazenamento.

\subsubsection{Análises químicas}

Nas Tabelas 8, 9 e 10 encontram-se os valores médios dos atributos químicos constatados nas amostras do produto final (sólidos solúveis totais, $\mathrm{pH}$ e acidez total titulável).

Os valores médios de sólidos solúveis totais, para os diferentes tratamentos de acidificação em estudo (Tabela 8), mostraram que este parâmetro praticamente não se alterou em função dos tratamentos, bem como ao longo do período de armazenamento. Nogueira et al. (1994 e 1997) e Cantarelli (1992) também não observaram alterações nos valores de sólidos solúveis totais em cenoura, couveflor e brotos de feijão acidificados e processados termicamente, submetidos a tratamentos diversos, e armazenados também por noventa dias.

Em relação ao pH (Tabela 9), verifica-se que ele foi mantido estável no valor desejável de 4,3, não variando em função dos tratamentos ou do período de armazenamento. Trabalhos com vagem (Fenjin He et al., 1989), com quiabo (Kotzekidou \& Roukas, 1987) e com pimenta (Saldana \& Meyer, 1981), todos acidificados, também constataram a estabilidade do $\mathrm{pH}$ requerido (sempre abaixo de 4,5), independentemente dos ácidos utilizados e ao longo do período de armazenamento. 
Na Tabela 10, observa-se que o maior valor da acidez total titulável referese sempre aos tratamentos com ácido acético (sem ou com cálcio). Em seus estudos com acidificação de cenouras, Nogueira et al. (1994) constataram resultados semelhantes, acerca da acidez titulável obtida de amostras que continham os mesmos ácidos orgânicos utilizados neste estudo. Pela Figura 11, fica claro esta diferença entre a acidez total titulável, encontrada para os tratamentos com ácido acético.

De acordo com o esperado, a estabilidade do produto elaborado ficou comprovada, na medida em que não ocorreram alterações significativas dos parâmetros químicos avaliados, durante o período de armazenamento considerado (30, 60 e 90 dias).

Tabela 8. Valores médios de sólidos solúveis totais ( ${ }^{\circ}$ Brix) dos cogumelos processados termicamente, em função do tempo de armazenamento.

\begin{tabular}{|c|c|c|c|c|c|c|c|c|c|c|c|}
\hline \multirow{3}{*}{$\begin{array}{l}\text { Tempo } \\
\text { (dias) }\end{array}$} & \multicolumn{10}{|c|}{ Tratamentos ácidos } & \multirow{3}{*}{ Médias } \\
\hline & \multicolumn{2}{|c|}{ Acético } & \multicolumn{2}{|c|}{ Cítrico } & \multicolumn{2}{|c|}{ Málico } & \multicolumn{2}{|c|}{ Lático } & \multicolumn{2}{|c|}{ Tartárico } & \\
\hline & I & II & I & II & I & II & I & II & I & II & \\
\hline 0 & 4,9 & 5,1 & 5,0 & 5,0 & 4,7 & 4,9 & 5,1 & 5,0 & 5,0 & 5,0 & $5,0^{\mathrm{A}}$ \\
\hline 30 & 5,2 & 4,6 & 4,5 & 4,5 & 5,1 & 5,0 & 5,0 & 5,0 & 5,0 & 5,2 & $5,1^{\mathrm{A}}$ \\
\hline 60 & 5,1 & 5,0 & 4,5 & 4,5 & 5,0 & 4,8 & 5,1 & 4,6 & 4,6 & 5,2 & $5,0^{\mathrm{A}}$ \\
\hline 90 & 5,1 & 4,7 & 5,1 & 5,1 & 4,7 & 5,1 & 4,9 & 4,7 & 4,7 & 5,0 & $4,9^{\mathrm{A}}$ \\
\hline Médias & $5,0^{\mathrm{A}}$ & $4,8^{\mathrm{A}}$ & $5,1^{\mathrm{A}}$ & $4,5^{\mathrm{A}}$ & $4,9^{\mathrm{A}}$ & $4,9^{\mathrm{A}}$ & $5,0^{\mathrm{A}}$ & $4,8^{\mathrm{A}}$ & $5,1^{\mathrm{A}}$ & $5,1^{\mathrm{A}}$ & - \\
\hline F (Trat.) & \multicolumn{10}{|c|}{1,69 n.s. } & . - \\
\hline $\mathrm{F}$ (tempo) & \multicolumn{10}{|c|}{0,22 n.s. } & - \\
\hline
\end{tabular}

I = sem cálcio; $\mathrm{II}$ = com cálcio n.s. = não significativo pelo teste de Tukey.

Médias com a mesma letra não diferem entre si ao nível de $5 \%$ de significância. 
Tabela 9. Valores médios de $\mathrm{pH}$ dos cogumelos processados termicamente, em função do tempo de armazenamento.

\begin{tabular}{|c|c|c|c|c|c|c|c|c|c|c|c|}
\hline \multirow{3}{*}{$\begin{array}{l}\text { Tempo } \\
\text { (dias) }\end{array}$} & \multicolumn{10}{|c|}{ Tratamentos ácidos } & \multirow{3}{*}{ Médias } \\
\hline & \multicolumn{2}{|c|}{ Acético } & \multicolumn{2}{|c|}{ Cítrico } & \multicolumn{2}{|c|}{ Málico } & \multicolumn{2}{|c|}{ Lático } & \multicolumn{2}{|c|}{ Tartárico } & \\
\hline & I & II & $\mathrm{I}$ & II & I & II & $\mathrm{I}$ & II & I & II & \\
\hline 0 & 4,28 & 4,28 & 4,29 & 4,29 & 4,27 & 4,27 & 4,27 & 427 & 4,27 & 4,28 & $4,29^{A}$ \\
\hline 30 & 4,29 & 4,28 & 4,27 & 4,27 & 4,28 & 4,27 & 4.28 & 4,29 & 4,29 & 4.28 & $4,28^{A}$ \\
\hline 6() & 4.28 & 4.29 & 4.27 & +.27 & +.26 & +.27 & +.29 & 4.26 & 4,28 & 4.27 & $+28^{\circ}$ \\
\hline 9() & 4,27 & 4,27 & 4,28 & 4,29 & 4,27 & 4,28 & 4,28 & 4.29 & 4,26 & 4.29 & $4,29^{\wedge}$ \\
\hline Médias & $4,29^{\wedge}$ & $4,28^{\mathrm{A}}$ & $4,27^{\bar{A}}$ & $4,28^{\AA}$ & $4,28^{\wedge}$ & $4,27^{\wedge}$ & $4,28^{\wedge}$ & $4,27^{\AA}$ & $4,29^{\AA}$ & $4,28^{\AA}$ & - \\
\hline F (Trat.) & \multicolumn{10}{|c|}{0,17 n.s. } & - \\
\hline $\mathrm{F}$ (tempo) & \multicolumn{10}{|c|}{0,11 n.s. } & - \\
\hline
\end{tabular}

I = sem cálcio; $\mathrm{II}$ = com cálcio

n.s. = não significativo pelo teste de Tukey.

Médias com a mesma letra não diferem entre si ao nível de $5 \%$ de significância.

Tabela 10. Valores médios de acidez total titulável (g ácido cítrico/100g) dos cogumelos processados termicamente, em função do tempo de armazenamento.

\begin{tabular}{|c|c|c|c|c|c|c|c|c|c|c|c|}
\hline \multirow{3}{*}{$\begin{array}{c}\text { Tempo } \\
\text { (dias) }\end{array}$} & \multicolumn{10}{|c|}{ Tratamentos ácidos } & \multirow{3}{*}{ Módias } \\
\hline & \multicolumn{2}{|c|}{ Acético } & \multicolumn{2}{|c|}{ Cítrico } & \multicolumn{2}{|c|}{ Málico } & \multicolumn{2}{|c|}{ Lático } & \multicolumn{2}{|c|}{ Tartárico } & \\
\hline & I & II & I & II & I & II & I & II & I & II & \\
\hline 0 & 0,396 & 0,385 & 0,210 & 0,290 & 0,211 & 0,213 & 0,220 & 0,240 & 0,210 & 0,250 & $0,263^{\mathrm{A}}$ \\
\hline 30 & 0,374 & 0,378 & 0,255 & 0,287 & 0,250 & 0,210 & 0,240 & 0,210 & 0,255 & 0,240 & $0,265^{\mathrm{A}}$ \\
\hline 60 & 0,388 & 0,367 & 0,285 & 0,257 & 0,210 & 0,245 & 0,210 & 0,210 & 0,257 & 0,240 & $0,267^{\mathrm{A}}$ \\
\hline 90 & 0,375 & 0,381 & 0,285 & 0,250 & 0,210 & 0,220 & 0,215 & 0,250 & 0.210 & 0,210 & $0,259^{\mathrm{A}}$ \\
\hline Médias & $0,386^{\mathrm{AB}}$ & $0,377^{\overline{\mathrm{AB}}}$ & $0,281^{\mathrm{A}}$ & $0,271^{\mathrm{A}}$ & $0,220^{\mathrm{A}}$ & $0,221^{\mathrm{A}}$ & $0,225^{\wedge}$ & $0,225^{\Lambda}$ & $0,237^{\AA}$ & $0,237^{\Lambda}$ & - \\
\hline F (Trat.) & \multicolumn{10}{|c|}{$62,88 * *$} & - \\
\hline F (tempo) & \multicolumn{10}{|c|}{0,27 n.s. } & - \\
\hline
\end{tabular}

$\mathrm{I}=$ sem cálcio; $\mathrm{II}$ = com cálcio

n.s. = não significativo pelo teste de Tukey.

** significativo ao nível de $5 \%$.

Médias com a mesma letra não diferem entre si ao nivel de $5 \%$ de significância. 


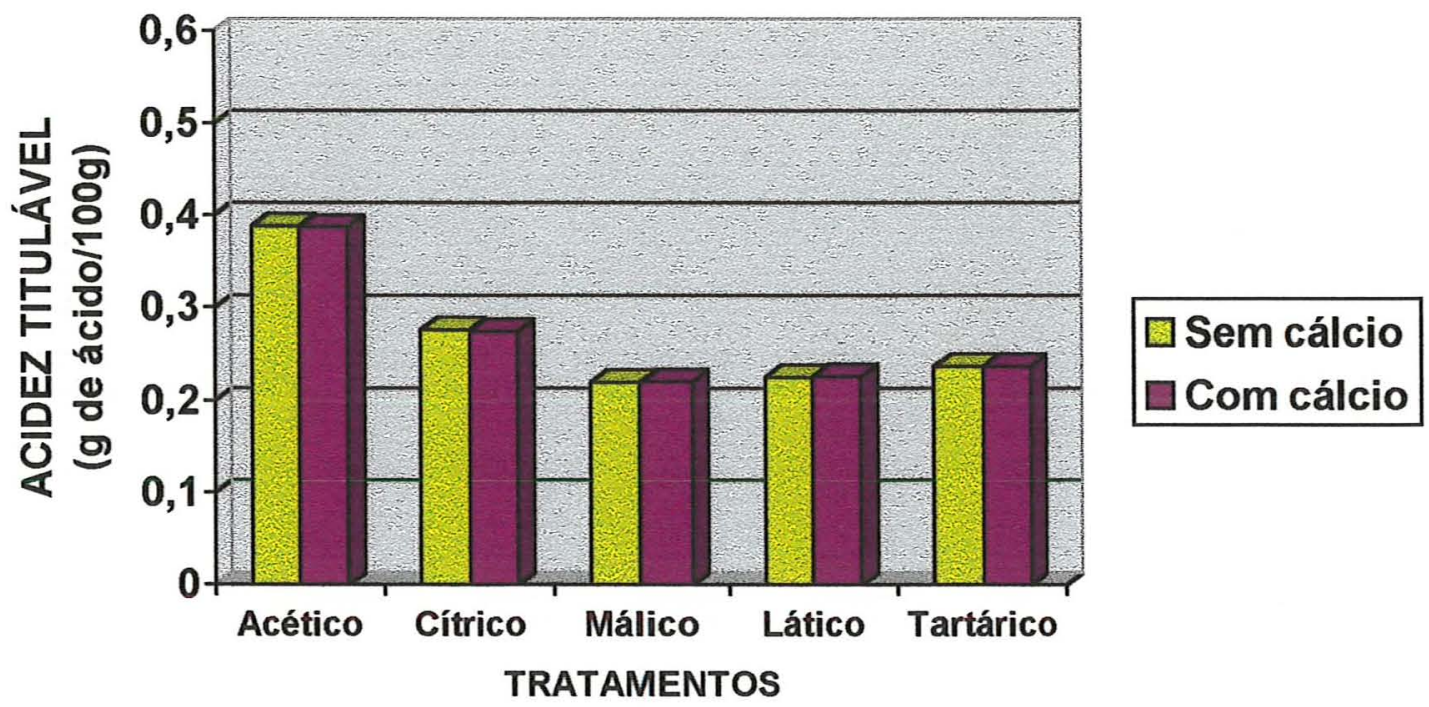

Figura 11. Valores médios de acidez titulável dos cogumelos processados termicamente, em função do tratamento.

\subsubsection{Análise sensorial}

A Tabela 11 mostra as médias dos resultados das análises sensoriais. Os atributos de qualidade avaliados foram: cor, aroma, sabor e textura. No que se refere ao aroma (atributo típico, característico em Pleurotus sajor-caju), a equipe de provadores teve bastante dificuldade em avaliá-lo nos diferentes tratamentos, ou seja, não se encontrou diferença quanto ao aroma, entre os diferentes tratamentos ou ao longo do tempo de armazenamento. Assim sendo, para efeito das análises estatísticas, desconsiderou-se o atributo de qualidade "aroma". 
O termo "Geral" encontrado na Tabela 11, representa a média aritmética entre os atributos avaliados pela análise sensorial, indicando portanto uma nota de qualidade geral para cada tratamento.

Tabela 11.Valores médios das análises sensoriais dos cogumelos acidificados e processados termicamente, em função dos tratamentos.

\begin{tabular}{|c|c|c|c|c|c|}
\hline \multirow{2}{*}{\multicolumn{2}{|c|}{ Tratamentos }} & \multicolumn{4}{|c|}{ Médias das notas } \\
\hline & & Cor & Textura & Sabor & Geral \\
\hline Testemunha & & $5,20^{\mathrm{BC}}$ & $6,01^{\mathrm{AB}}$ & $5,00^{C}$ & $5,40^{B}$ \\
\hline \multirow[t]{2}{*}{ Ácido acético } & $\mathrm{I}$ & $6,63^{\mathrm{A}}$ & $6,56^{\mathrm{ABC}}$ & $7,79^{\mathrm{AB}}$ & $6,99^{A}$ \\
\hline & II & $7,06^{\mathrm{A}}$ & $6,54^{\mathrm{ABC}}$ & $7,31^{\mathrm{ABC}}$ & $6,96^{\mathrm{A}}$ \\
\hline \multirow[t]{2}{*}{ Ácido cítrico } & I & $6,10^{\mathrm{AB}}$ & $6,01^{\mathrm{AB}}$ & $8,04^{\mathrm{A}}$ & $6,88^{\mathrm{A}}$ \\
\hline & II & $6,15^{\mathrm{AB}}$ & $6,50^{\mathrm{ABC}}$ & $8,01^{\wedge}$ & $6,72^{A}$ \\
\hline \multirow[t]{2}{*}{ Ácido málico } & I & $5,10^{\mathrm{BC}}$ & $6,56^{\mathrm{ABC}}$ & $7,49^{\mathrm{ABC}}$ & $6,38^{\mathrm{A}}$ \\
\hline & II & $5,40^{\mathrm{BC}}$ & $6,57^{\mathrm{ABC}}$ & $7,73^{\wedge B}$ & $6,57^{A}$ \\
\hline \multirow[t]{2}{*}{ Ácido lático } & I & $6,56^{\mathrm{A}}$ & $6,00^{\mathrm{AB}}$ & $7,73^{\mathrm{ABC}}$ & $6,71^{\mathrm{A}}$ \\
\hline & II & $6,56^{\mathrm{A}}$ & $6,37^{\mathrm{ABC}}$ & $7,29^{\mathrm{ABC}}$ & $6,71^{\mathrm{A}}$ \\
\hline \multirow[t]{2}{*}{ Ácido tartárico } & l & $5,88^{\mathrm{AB}}$ & $6,37^{\wedge \mathrm{BC}}$ & $7,42^{\mathrm{ABC}}$ & $6,56^{\mathrm{A}}$ \\
\hline & II & $6,19^{\mathrm{AB}}$ & $6,57^{\mathrm{ABC}}$ & $7,29^{\mathrm{ABC}}$ & $6,68^{\mathrm{A}}$ \\
\hline
\end{tabular}

$\mathrm{I}=$ Sem cálcio; $\mathrm{II}=$ Com cálcio.

Médias com as mesmas letras não diferem entre si, ao nível de $5 \%$ de significância. 
Os resultados médios encontrados demonstraram a preferência dos provadores pelo produto acidificado, em comparação ao produto não submetido à acidificação (testemunha). Cantarelli (1996) também confirmou esta preferência por produtos mais ácidos, em relação ao broto de feijão acidificado.

$\mathrm{Na}$ Figura 12 pode-se observar as médias gerais das análises sensoriais realizadas, em função dos tratamentos.

A avaliação subjetiva da cor mostrou que as menores médias foram dadas ao produto referente à testemunha, e ao produto que recebeu tratamento com ácido málico (com e sem cálcio). Ainda em relação à cor, os melhores tratamentos eleitos pela equipe de provadores, foram os tratamentos com ácido acético e ácido lático, independentemente da adição do cálcio (Figura 13).

Em relação à textura, a avaliação subjetiva não conseguiu retratar as diferenças obtidas na avaliação objetiva, isto é, as diferenças significativas entre os valores médios de textura constatados objetivamente pelo texturômetro, graças à adição do cloreto de cálcio, não foram percebidas pela equipe de provadores selecionada (Figura 14).

No que se refere ao sabor do produto elaborado, o melhor tratamento eleito pela análise sensorial foi aquele com ácido cítrico, independentemente da adição de cálcio. O tratamento que recebeu as menores notas para o sabor foi a testemunha; comprovando assim, a preferência dos consumidores por produtos acidificados (Figura 15). 


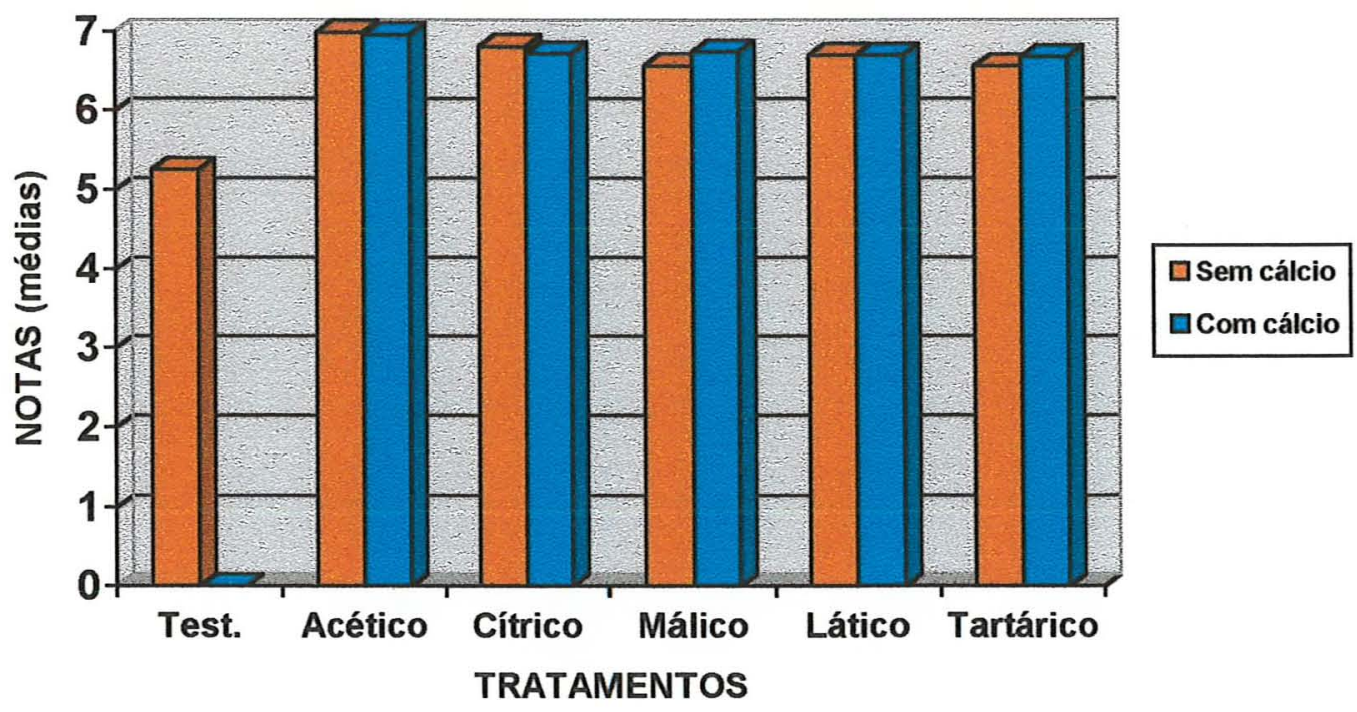

Figura 12. Valores médios das notas obtidas na avaliação sensorial, quanto à qualidade geral dos cogumelos processados termicamente.

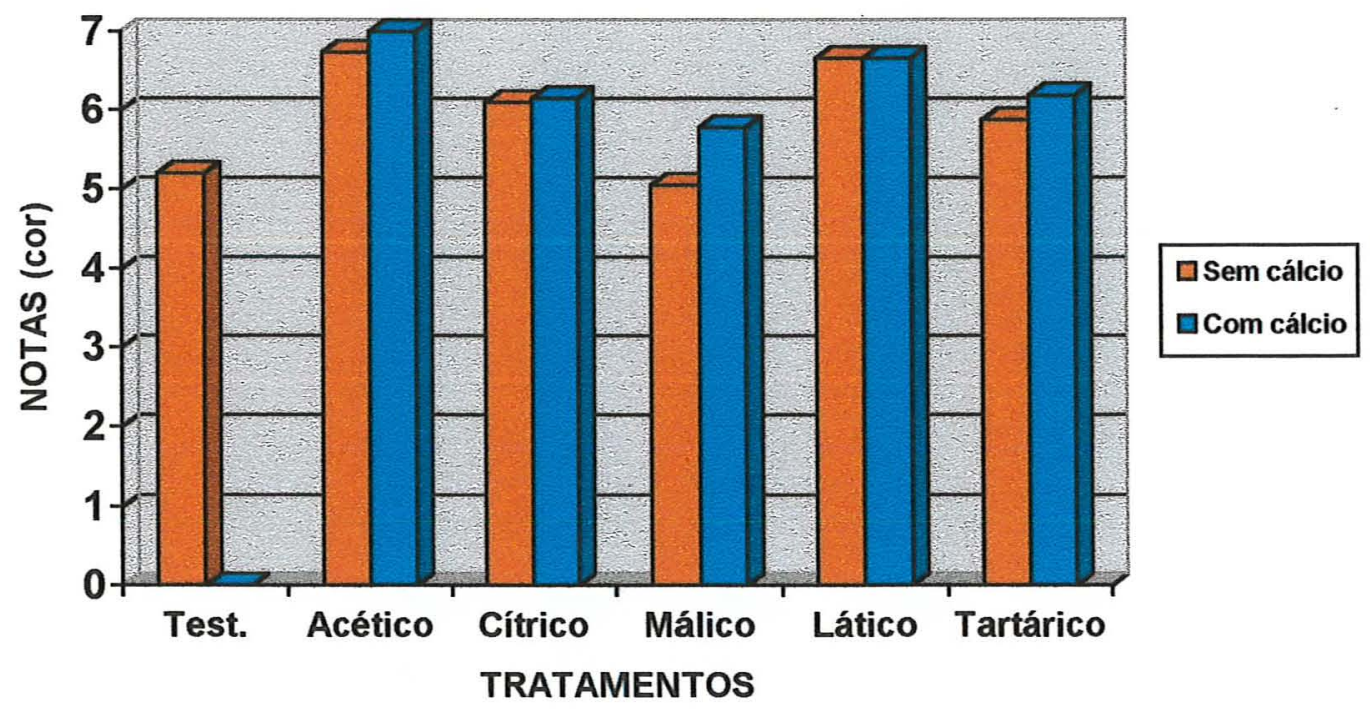

Figura 13. Valores médios das notas obtidas na avaliação sensorial, quanto à cor dos cogumelos processados termicamente. 


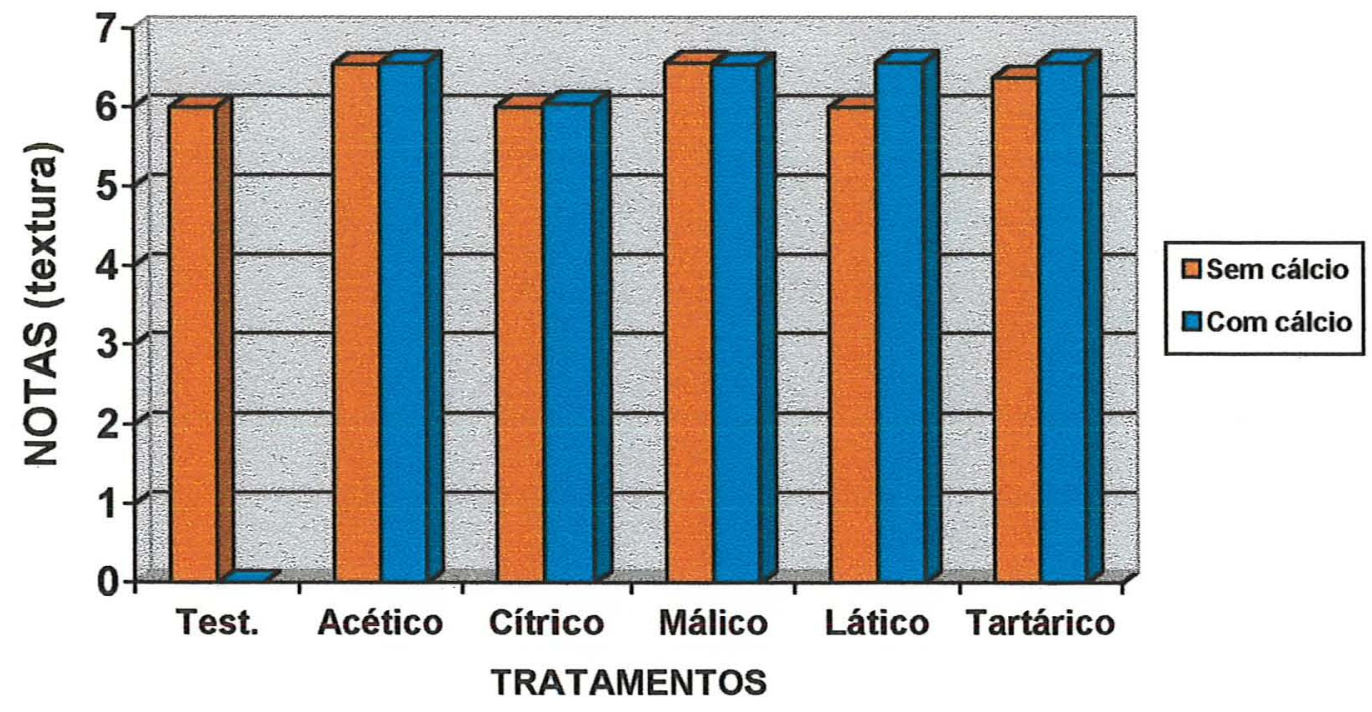

Figura 14. Valores médios das notas obtidas na avaliação sensorial, quanto à textura dos cogumelos processados termicamente.

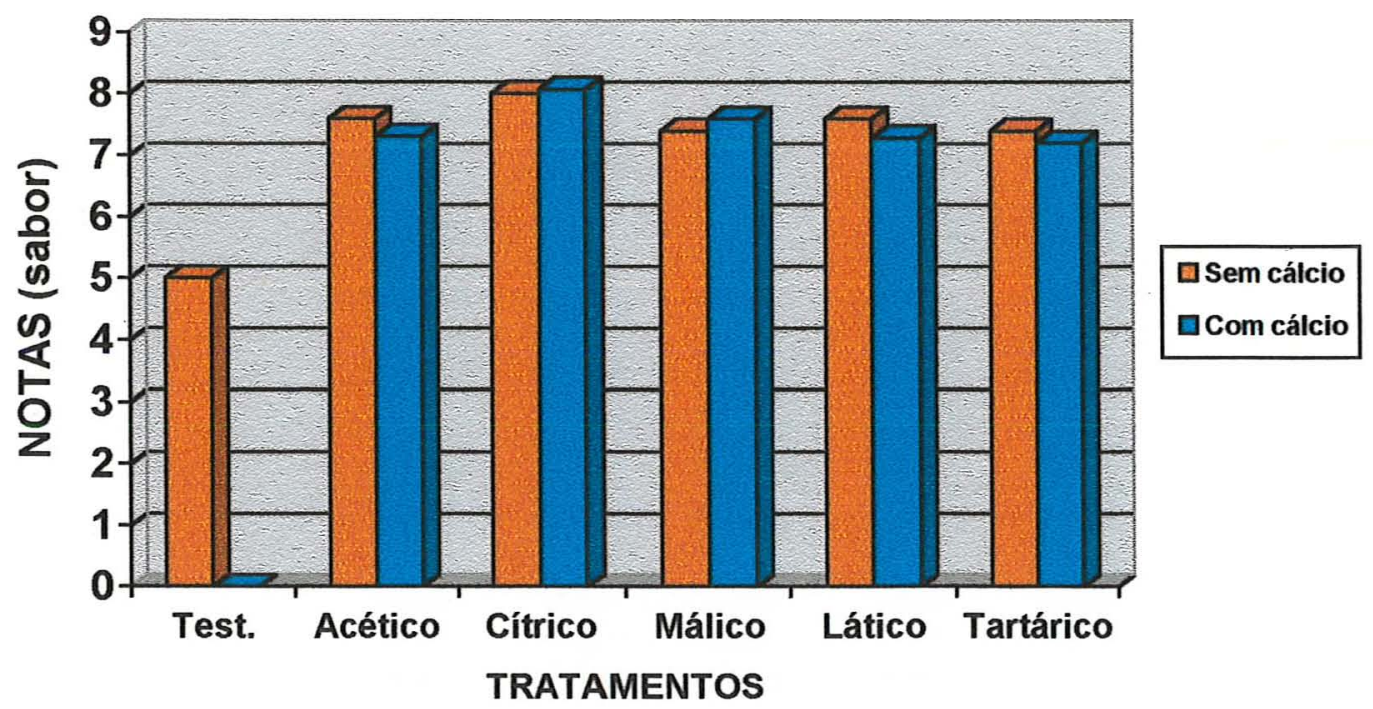

Figura 15. Valores médios das notas obtidas na avaliação sensorial, quanto ao sabor dos cogumelos processados termicamente. 
A Tabela 12 demonstra os valores médios das análises sensoriais das conservas de Pleurotus sajor-caju, em função do tempo de armazenamento.

Os resultados médios obtidos indicam que as análises sensoriais realizadas em diferentes períodos ( 30,60 e 90 dias), não alteraram as notas médias dadas aos atributos de qualidade, nos diferentes tratamentos.

Tabela 12. Valores médios das análises sensoriais dos cogumelos acidificados e processados termicamente, em função do tempo de armazenamento.

\begin{tabular}{|c|c|c|c|c|}
\hline \multirow{2}{*}{$\begin{array}{c}\text { Tempo } \\
(\text { dias })\end{array}$} & \multicolumn{4}{|c|}{ Médias das notas } \\
\cline { 2 - 5 } & Cor & Textura & Sabor & Média \\
\hline 30 & $6,40^{\mathrm{A}}$ & $6,29^{\mathrm{A}}$ & $7,51^{\mathrm{A}}$ & $6,73^{\mathrm{A}}$ \\
60 & $6,49^{\mathrm{A}}$ & $6,39^{\mathrm{A}}$ & $7,70^{\mathrm{A}}$ & $6,86^{\mathrm{A}}$ \\
90 & $6,56^{\mathrm{A}}$ & $6,30^{\mathrm{A}}$ & $7,63^{\mathrm{A}}$ & $6,83^{\mathrm{A}}$ \\
& & & & \\
\hline
\end{tabular}

Médias com as mesmas letras não diferem entre si, ao nível de $5 \%$ de significância.

A Figura 16 mostra os resultados médios (notas) das análises sensoriais, em função do tempo de armazenamento. Os resultados gerais obtidos nas avaliações sensoriais demonstram que não houveram alterações significativas em relação às notas conferidas aos atributos de qualidade, em função do tempo de armazenamento. Assim sendo, a equipe de provadores responsável pelas análises sensoriais, confirmou a estabilidade do produto elaborado, no decorrer do tempo estabelecido. 


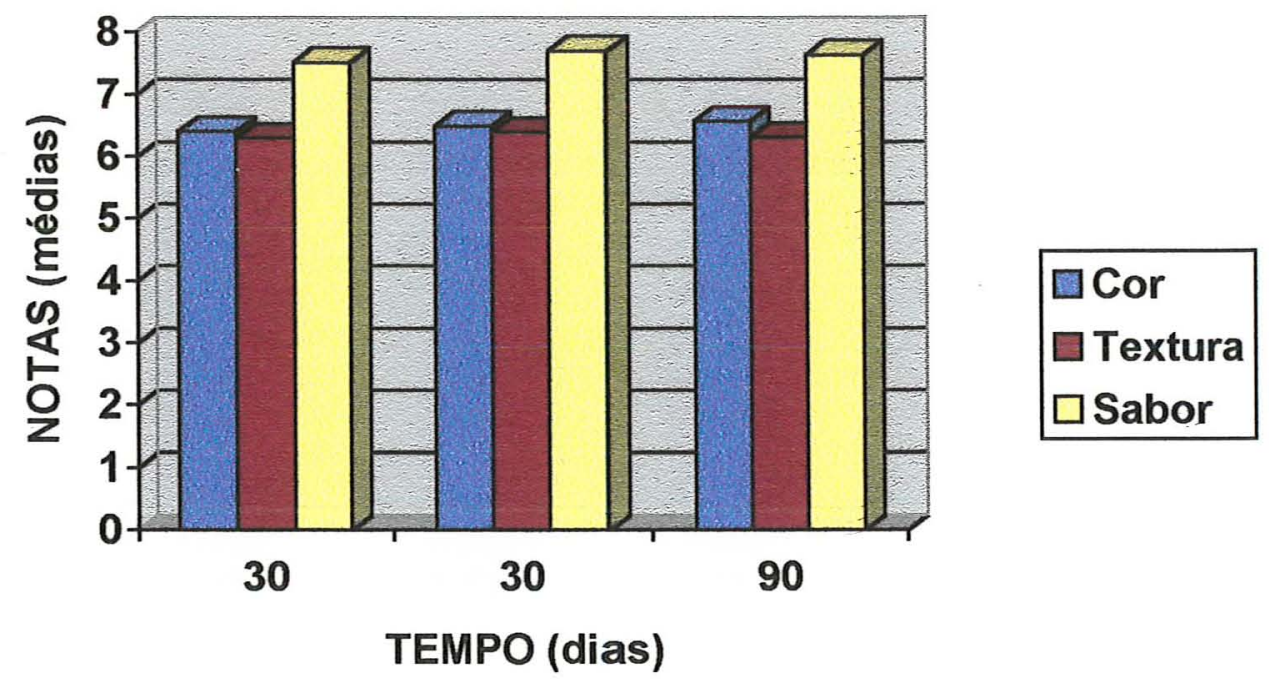

Figura 16. Valores médios da análise sensorial das conservas de cogumelos, em função do tempo de armazenamento.

É importante finalizar, ressaltando que durante todo o período de análises das conservas, o aspecto geral dos vidros, de suas tampas, da salmoura e do produto, propriamente dito, foi sendo acompanhado criteriosamente. E ao final dos 90 dias, nenhuma alteração pôde ser detectada.

\subsubsection{Análises microbiológicas}

A avaliação microbiológica dos produtos finais indicou a alta eficiência dos processos empregados, uma vez que após o período de estocagem, não se detectou qualquer atividade biológica nos mesmos. 


\subsubsection{Curva de secagem}

A desidratação foi conduzida até atingir o teor de umidade de equilíbrio, o que se sucedeu cerca de 8 horas após o início do processo. A Figura 17 representa a curva de desidratação obtida dos dados da razão de umidade em função de diferentes tempos de desidratação, à temperatura de $70^{\circ} \mathrm{C}$. Os valores apresentados no gráfico são médias aritméticas de 2 repetições.

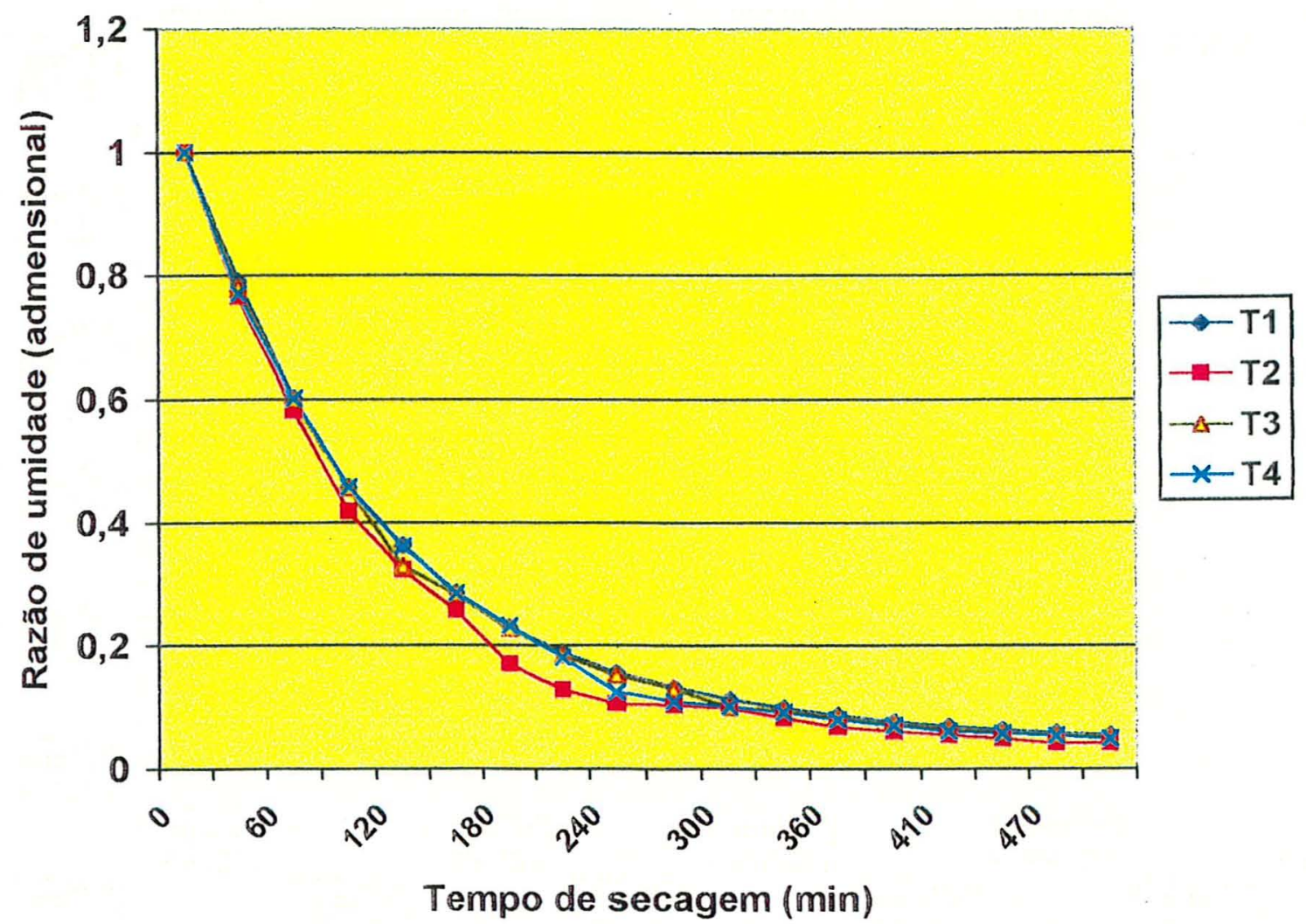

Figura 17. Curva média de desidratação dos dados da razão de umidade em função dos diferentes tempos de desidratação, à temperatura de $70^{\circ} \mathrm{C}$ (T1 = Testemunha; T2 = Ácido cítrico; T3 = Cloreto de cálcio; $\mathrm{T} 4=$ Ácido cítrico + Cloreto de cálcio). 


\subsubsection{Análises fisicas}

As análises de peso bruto e peso líquido foram realizadas com os cogumelos secos, sem posterior reidratação. Os resultados médios obtidos estão expressos nas Tabelas 13 e 14. É interessante observar os pequenos valores de peso líquido, uma vez que a água retirada dos cogumelos representa quase que a totalidade de seu peso, em gramas.

Jorge (1989) esclarece que os estudos sobre desidratação de cogumelos comestíveis são deveras importantes, uma vez que a operação unitária de secagem visa principalmente a redução do peso, para fins de armazenamento e transporte, sem detrimento de suas características organolépticas e nutricionais.

Tabela 13. Valores médios do peso bruto $(\mathrm{g})$ dos recipientes dos cogumelos desidratados.

\begin{tabular}{|c|c|c|c|c|c|}
\hline Tempo (dias) & T1 & T2 & T3 & T4 & Médias \\
\hline 0 & 176,1 & 183,5 & 178,9 & 181,2 & $179,9^{\mathrm{A}}$ \\
30 & 180,5 & 179,8 & 180,7 & 181,1 & $180,5^{\mathrm{A}}$ \\
60 & 184,8 & 176,8 & 180,9 & 181,7 & $181,5^{\mathrm{A}}$ \\
90 & 176,4 & 182,9 & 183,1 & 180,8 & $180,7^{\mathrm{A}}$ \\
\hline Médias & $189,4^{\mathrm{A}}$ & $180,7^{\mathrm{A}}$ & $180,9^{\mathrm{A}}$ & $181,2^{\mathrm{A}}$ & - \\
\hline F (Trat.) & \multicolumn{5}{|c|}{ 2,06 n.s. } \\
\hline F (Tempo) & \multicolumn{5}{|c|}{1,79 n.s. } \\
\hline
\end{tabular}

T1, T2, T3 e T4 = tratamentos n.s. = não significativo, pelo teste de Tukey Médias com a mesma letra não diferem entre si, ao nível de $5 \%$ de significância. 
Tabela 14. Valores médios do peso líquido (g) dos recipientes dos cogumelos desidratados.

\begin{tabular}{|c|c|c|c|c|c|}
\hline Tempo (dias) & T1 & T2 & T3 & T4 & Médias \\
\hline 0 & 9,7 & 10,6 & 10,1 & 9,9 & $10,1^{\mathrm{A}}$ \\
30 & 9,9 & 10,7 & 10,3 & 10,5 & $10,4^{\mathrm{A}}$ \\
60 & 10,1 & 10,9 & 10,7 & 10,9 & $10,6^{\mathrm{A}}$ \\
90 & 10,0 & 10,8 & 10,8 & 10,6 & $10,5^{\AA}$ \\
\hline Médias & $9,9^{\mathrm{A}}$ & $10,7^{\mathrm{A}}$ & $10,5^{\mathrm{A}}$ & $10,5^{\mathrm{A}}$ & - \\
\hline F (Trat.) & \multicolumn{5}{|c|}{1,39 n.s. } \\
\hline F (Tempo) & \multicolumn{5}{|c|}{ 0,33 n.s. } \\
\hline
\end{tabular}

T1, T2, T3 e T4 = tratamentos

n.s. = não significativo, pelo teste de Tukey

Médias com a mesma letra não diferem entre si, ao nível de $5 \%$ de significância.

A reidratação dos cogumelos secos, conforme metodologia proposta por Jorge (1989), e já descrita anteriormente, possibilitou a análise física de rendimento, que obteve valores médios de $82,5 \pm 2,0 \%$, independentemente do tratamento utilizado.

As análises físicas de textura também foram realizadas com os cogumelos secos reidratados, conforme metodologia descrita anteriormente. Os resultados médios obtidos não indicaram qualquer diferença significativa entre os diferentes tratamentos, bem como entre o período de armazenamento (Tabela 15).

É importante ressaltar que os valores de textura encontrados para os cogumelos reidratados, pelas análises objetivas no texturômetro, são sempre maiores que aqueles encontrados, nos cogumelos acidificados, em conserva, porém menores que os valores encontrados na matéria-prima, "in natura”. Esta 
observação confirma o proposto por Sturion (1994), que relatando sobre possíveis formas de processamento de cogumelos, sugere que cogumelos secos e reidratados resultam em valores de textura maiores que aqueles de produtos em conserva.

Tabela 15. Valores médios da textura (Lbf/g) dos cogumelos desidratados.

\begin{tabular}{|c|c|c|c|c|c|}
\hline Tempo (dias) & T1 & T2 & T3 & T4 & Médias \\
\hline 0 & 5,71 & 5,39 & 5,51 & 5,49 & $5,53^{\mathrm{A}}$ \\
30 & 5,54 & 4,89 & 5,02 & 4,88 & $5,03^{\mathrm{A}}$ \\
60 & 5,32 & 5,19 & 5,08 & 5,21 & $5,19^{\mathrm{A}}$ \\
90 & 4,99 & 5,51 & 5,55 & 5,62 & $5,42^{\mathrm{A}}$ \\
\hline Médias & $5,39^{\mathrm{A}}$ & $5,25^{\mathrm{A}}$ & $5,29^{\mathrm{A}}$ & $5,31^{\mathrm{A}}$ & - \\
\hline F (Trat.) & \multicolumn{5}{|c}{ 1,87 n.s. } \\
\hline F (Tempo) & \multicolumn{5}{|c|}{ 0,79 n.s. } \\
\hline
\end{tabular}

$\mathrm{T} 1, \mathrm{~T} 2, \mathrm{~T} 3$ e $\mathrm{T} 4=$ tratamentos n.s. = não significativo, pelo teste de Tukey

Médias com a mesma letra não diferem entre si, ao nível de 5\% de significância.

\subsubsection{Análises químicas}

Os resultados médios das análises de $\mathrm{pH}$ e sólidos solúveis totais, realizadas com os cogumelos reidratados, estão expressos nas Tabelas 16 e 17 . Os valores encontrados indicam que não ocorreram diferenças significativas nos parâmetros químicos avaliados, dentre os tratamentos, nem sequer ao longo do período de armazenamento. 
Comprovou-se a estabilidade do produto desidratado no decorrer do armazenamento, pela manutenção de suas características químicas, indicando que não houve reabsorção de água pelo produto seco. Jorge (1989) salienta que o maior problema em relação à cogumelos secos comercialmente utilizados (Agaricus sp.), refere-se à reabsorção de umidade pelo produto já embalado, o que acarreta em alterações organolépticas indesejáveis.

Tabela 16. Valores médios de $\mathrm{pH}$ dos cogumelos desidratados.

\begin{tabular}{|c|c|c|c|c|c|}
\hline Tempo (dias) & T1 & T2 & T3 & T4 & Médias \\
\hline 0 & 6,02 & 5,99 & 6,00 & 6,01 & $6,01^{\mathrm{A}}$ \\
30 & 5,98 & 6,00 & 5,98 & 6,00 & $5,98^{\mathrm{A}}$ \\
60 & 5,93 & 5,98 & 5,94 & 5,94 & $5,95^{\mathrm{A}}$ \\
90 & 6,02 & 6,00 & 6,01 & 6,01 & $6,00^{\mathrm{A}}$ \\
\hline Médias & $5,99^{\mathrm{A}}$ & $6,00^{\mathrm{A}}$ & $5,98^{\mathrm{A}}$ & $5,99^{\mathrm{A}}$ & - \\
\hline F (Trat.) & \multicolumn{5}{|c}{1,06 n.s. } \\
\hline F (Tempo) & \multicolumn{5}{|c|}{1,37 n.s. } \\
\hline
\end{tabular}

$\mathrm{T} 1, \mathrm{~T} 2, \mathrm{~T} 3$ e $\mathrm{T} 4$ = tratamentos

n.s. = não significativo, pelo teste de Tukey

Médias com a mesma letra não diferem entre si, ao nível de $5 \%$ de significância. 
Tabela 17. Valores médios de sólidos solúveis $\left({ }^{\circ}\right.$ Brix $)$ dos cogumelos desidratados.

\begin{tabular}{|c|c|c|c|c|c|}
\hline Tempo (dias) & $\mathrm{T} 1$ & $\mathrm{~T} 2$ & T3 & T4 & Médias \\
\hline 0 & 4,5 & 5,0 & 4,0 & 4,0 & $4,13^{\mathrm{A}}$ \\
\hline 30 & 4,5 & 4,5 & 5,0 & 5,0 & $4,75^{\mathrm{A}}$ \\
\hline 60 & 5,0 & 5,5 & 4,5 & 4,5 & $4,88^{1}$ \\
\hline 90 & 5,5 & 5,0 & 5,0 & 5,0 & $5,13^{\wedge}$ \\
\hline Médias & $4,88^{\AA}$ & $5,00^{A}$ & $4,63^{\Lambda}$ & $4,63^{\Lambda}$ & - \\
\hline F (Trat.) & \multicolumn{4}{|c|}{1,04 n.s. } & - \\
\hline $\mathrm{F}$ (Tempo) & \multicolumn{4}{|c|}{0,47 n.s. } & - \\
\hline
\end{tabular}

T1, T2, T3 e T4 = tratamentos

n.s. = não significativo, pelo teste de Tukey

Médias com a mesma letra não diferem entre si, ao nível de $5 \%$ de significância.

\subsubsection{Análise sensorial}

Os resultados das avaliações sensoriais estão expressos na Tabela 18 , e as médias gerais relativas à cada tratamento, estão expressas na Figura 18. Ao se tecer comparações do produto que recebeu qualquer um dos tratamentos prévios de imersão, com o produto testemunha (que foi submetido à secagem, sem qualquer tratamento químico de imersão), percebe-se facilmente que a equipe de provadores avaliou o produto tratado como sendo melhor, em relação ao produto unicamente seco, principalmente no que diz respeito ao sabor. 
Tabela 18. Valores médios das análises sensoriais dos cogumelos desidratados, em função dos tratamentos

\begin{tabular}{|l|c|c|c|c|}
\hline \multirow{2}{*}{ Tratamentos } & \multicolumn{4}{|c|}{ Médias das notas } \\
\cline { 2 - 5 } & Cor & Textura & Sabor & Geral \\
\hline Testemunha (T1) & $6,21^{\mathrm{b}}$ & $6,38^{\mathrm{a}}$ & $6,12^{\mathrm{a}}$ & $6,21^{\mathrm{b}}$ \\
Ácido cítrico (T2) & $7,64^{\mathrm{a}}$ & $6,42^{\mathrm{a}}$ & $7,72^{\mathrm{ab}}$ & $7,30^{\mathrm{a}}$ \\
Cloreto de cálcio - (T3) & $6,99^{\mathrm{b}}$ & $6,47^{\mathrm{a}}$ & $7,29^{\mathrm{ab}}$ & $6,99^{\mathrm{a}}$ \\
Ácido cítrico $+\mathrm{CaCl}_{2}(\mathrm{~T} 4)$ & $7,44^{\mathrm{a}}$ & $6,49^{\mathrm{a}}$ & $7,58^{\mathrm{ab}}$ & $7,20^{\mathrm{a}}$ \\
\hline
\end{tabular}

Médias com as mesmas letras não diferem entre si ao nível de 5\% de significância.

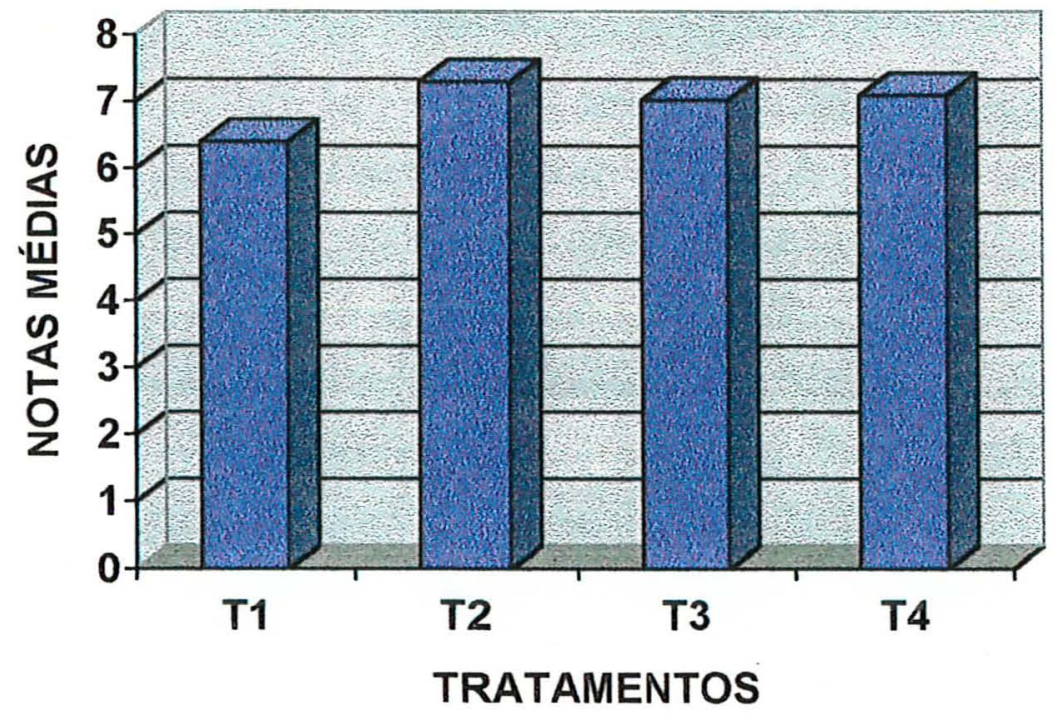

Figura 18. Valores médios das notas obtidas na avaliação sensorial, quanto à qualidade geral dos cogumelos desidratados. 
Em relação á cor do produto final, os melhores tratamentos eleitos pela equipe de análise sensorial foram aqueles em que a solução de imersão prévia à secagem, continha ácido cítrico (T2= solução $0,5 \%$ de ácido cítrico e $\mathrm{T} 4=$ =solução $0,5 \%$ de ácido cítrico e $0,2 \%$ de cloreto de cálcio). Os cogumelos tratados com ácido cítrico adquiriram uma coloração dourada após a secagem, que os diferenciou dos demais (Figura 19).

No que se refere à textura, a equipe de provadores não conseguiu detectar diferenças entre um tratamento e outro, como era de se esperar, visto que na avaliação objetiva da textura, não foram encontradas diferenças significativas entre os tratamentos (Figura 20).

Quanto ao sabor, as maiores médias também foram alcançadas pelas amostras dos cogumelos que receberam tratamento com ácido cítrico (T2 e T4), confirmando os resultados de Jorge (1989), em relação à avaliação sensorial de cogumelos secos (Agaricus bisporus) que receberam o mesmo tratamento prévio á secagem (Figura 21).

É importante finalizar, ressaltando algumas sugestões de pesquisa, visando melhorias nos produtos desenvolvidos. Nos cogumelos acidificados, por exemplo, a aparência geral da conserva apresenta obstáculos à sua ampla aceitação pelo consumidor. Assim sendo, há que se pesquisar incrementos no aspecto do produto, como a adição de condimentos, juntamente com os cogumelos; a melhor disposição dos corpos de frutificação no interior da embalagem; etc. Nos cogumelos secos, há que se utilizar, por exemplo, embalagens adequadas que sejam capazes de impedir trocas de umidade com o ambiente, a custos reduzidos; tratamentos prévios à secagem que melhorem a aparência do produto final; dentre outros. Tanto no caso de cogumelos acidificados, como no caso do produto seco, há que se pesquisar, por exemplo, as possíveis alterações nutricionais ocorridas (perdas/ganhos). 


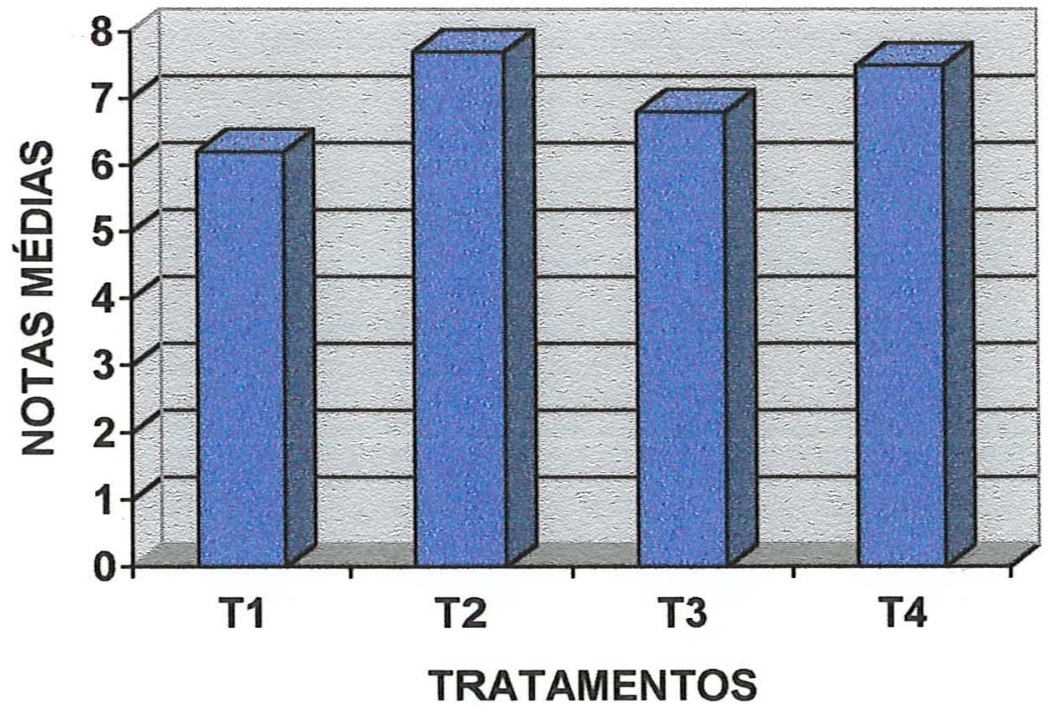

Figura 19. Valores médios das notas obtidas na avaliação sensorial, quanto à cor dos cogumelos desidratados.

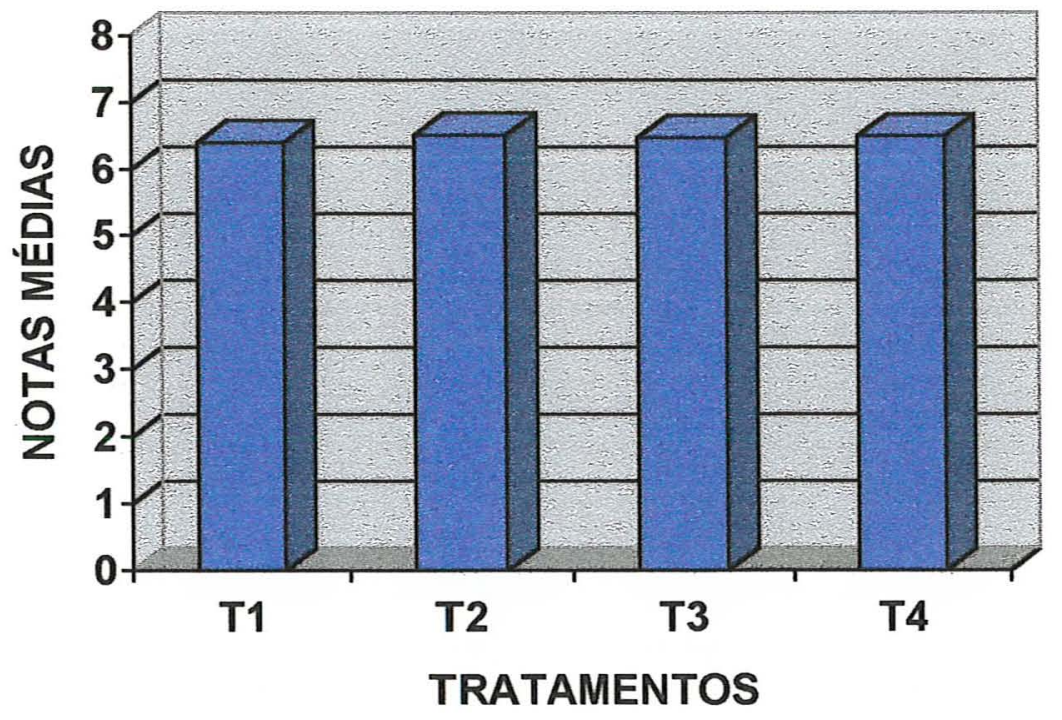

Figura 20. Valores médios das notas obtidas na avaliação sensorial, quanto à textura dos cogumelos desidratados. 


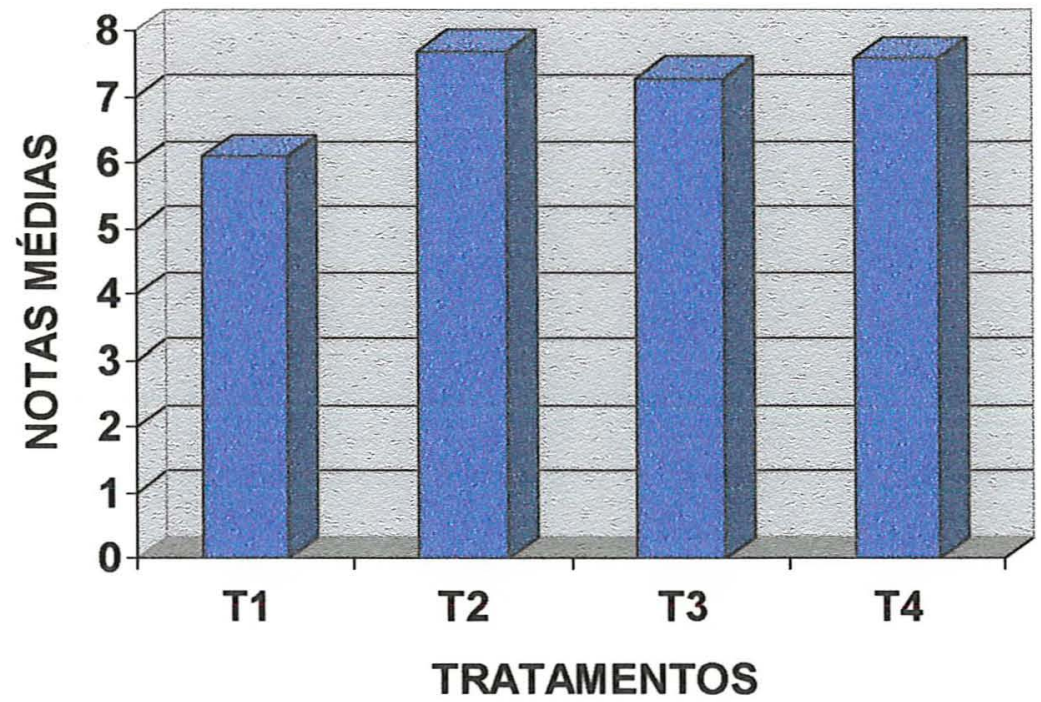

Figura 21. Valores médios das notas obtidas na avaliação sensorial, quanto ao sabor dos cogumelos desidratados. 


\section{CONCLUSÕES}

Os resultados obtidos, dentro das condições experimentais em que foi realizado este trabalho, possibilitaram as seguintes conclusões:

- As curvas de acidificação, utilizadas para determinar a quantidade necessária de cada ácido, a fim de se obter um $\mathrm{pH}$ de equilíbrio de 4,3 na conserva de cogumelos Pleurotus sajor-caju, variaram com o tipo de ácido utilizado, mostrando que o tartárico foi o ácido utilizado em menor quantidade (em peso) e o ácido acético em maior quantidade. Assim sendo, em uma escala de ordem decrescente, teríamos os ácidos: acético, cítrico, málico, lático e tartárico.

- A análise objetiva da textura, atributo de maior problema no caso de cogumelos acidificados e processados termicamente, demonstrou que a adição de cloreto de cálcio resultou em um produto com valores maiores de textura, independentemente do ácido utilizado.

- De maneira geral, a preferência pelo produto acidificado, em relação ao produto sem acidificação, foi notória. O produto acidificado recebeu, na análise sensorial, notas gerais sempre superiores que as notas dadas ao produto nãoácido. O ácido, portanto, atuou como agente de realce principalmente do sabor. 
- A acidificação com os ácidos acético e cítrico foram as consideradas mais adequadas, pela análise sensorial, principalmente no que tange aos atributos cor e sabor.

- A adição do cloreto de cálcio, nas avaliações sensoriais, não apresentou efeito positivo, ou melhor, os resultados não apresentaram diferenças significativas, quando comparados às amostras sem $\mathrm{CaCl}_{2}$. F embora nas avaliações objetivas de textura, detectou-se diferenças significativas entre os produtos adicionados de cálcio e os produtos sem cálcio, nas avaliações sensoriais, estas diferenças não foram detectadas.

- $\mathrm{O}$ aspecto da salmoura do produto sem $\mathrm{CaCl}_{2}$ era visivelmente turvo, aos 90 dias de armazenamento, ao passo que a salmoura com $\mathrm{CaCl}_{2}$ apresentava-se translúcida, no mesmo período. O cálcio, portanto, agiu como importante fator de retenção de sais, provocando diferenças significativas na textura do produto e no aspecto da solução salina acidificada.

- As avaliações microbiológicas do produto final demonstraram a eficiência do processo empregado, e, consequentemente, a praticabilidade de se processar termicamente cogumelos acidificados da espécie Pleurotus sajor-caju, resultando em um produto seguro e de maior durabilidade.

- A secagem a $70^{\circ} \mathrm{C}$, por 8-9 horas (ou até que se atinjisse a umidade de $10 \%$ base úmida), com circulação forçada de ar, foi considerada adequada para conservação do produto, pelo período de 90 dias, no que tange às suas qualidades organolépticas. 
- A textura do cogumelo reidratado não foi a mesma do fresco, mas foi mais firme do que a do produto em salmoura, de acordo com os testes objetivos, realizados com o texturômetro empregado neste trabalho.

- Os tratamentos de imersão em ácido cítrico são benéficos com relação à cor do produto desidratado, que adquire uma tonalidade dourada. Além disso, as amostras imersas nas soluções de ácido cítrico foram avaliadas, sensorialmente. por notas sempre maiores que as amostras não tratadas desta maneira. A imersão em cloreto de cálcio não apresentou vantagens expressivas em relação à testemunha.

- Tanto a acidificação/processamento térmico, como a desidratação, são técnicas viáveis de se aplicar para a conservação de cogumelos da espécie Pleurotus sajor-caju. Os produtos finais elaborados apresentaram boa qualidade, sob os pontos de vista físico, químico e organoléptico.

- Na acidificação, não foram comprovadas grandes vantagens na utilização de um ácido em relação á outro. Na operação de secagem, não foi comprovada necessidade real de tratamentos pré-processamento. No entanto, os produtos elaborados (acidificados/processados termicamente e secos) resultaram em produtos de boa qualidade, e estáveis ao longo do período analisado. 


\section{REFERÊNCIAS BIBLIOGRÁFICAS}

ANGLE, R.Y; TAMHANE, D.V. Mushrooms: an exotic source of nutritious and palatable food. Indian Food Packer, v.28, nº 5, p.22-33, 1974.

ANONYMOUS. Fermentation may answer needs for natural foods low-energy process. Food Product Development, v. 14, n 9, p.48, 1980.

Associação Brasileira de Cultivadores de Cogumelos. São Paulo, 1997 (Comunicação Pessoal).

ASSOCIATION OF OFFICIAL ANALYTICAL CHEMISTS - Official methods of analysis. Washington, 1985. 1094p.

BANO, Z.; RAJARATHNAM, S.; NAGARAJA, N. Some aspects on the cultivation of Pleurotus flabellatus in India. Mushroom Science, v.10, n.2, p.597-608, 1978 .

BANO, Z.; RAJARATHNAM, S. Pleurotus mushroom as nutritional food. In: CHANG, S.T.; QUIMIO, T.H. Tropical mushrooms. Hong Kong: The Chinese University Press, 1982. p.363-80. 
BANO, Z.; RAJARATHNAM, S. Pleurotus mushrooms. Part II. Chemical composition, preservation, and role an human food. Critical Reviews in Food Science and Nutrition, v.27, $\mathrm{n}^{\mathrm{o}}$ 2, p.87-158, 1988.

BARTHOLOMAI, G.B. Efecto del escaldado sobre la cinética del secado y la calidad di champinones deshidratados en corriente de aire y por liofilización. Agroquímica y 'Tecnologia de $\Lambda$ limentos, v. 14, 11"3, p.429-438, 1974.

BERHARDT, L.W. Processamento térmico de cogumelos. I Encontro Nacional sobre Cogumelos Comestíveis - Anais, Mogi das Cruzes, SP, 1980.

BERNHARDT, L.W. Enlatamento de hortaliças acidificadas. In: PASCHOALINO, J.E. Processamento de hortaliças. Campinas: ITAL, 1989, p.34-37.

BONONI, V.L.R.; CAPELARI, M.; MAZIERO, R.; TRUFEM, S.F.B. Cultivo de cogumelos comestíveis. São Paulo: Ícone, 1995. 206p.

BONONI, V.L.R.; MAZIERO, R.; CAPELARI, M. Pleurotus ostreatus cultivation in Brasil. Mushroom Science, v. 13, nº 6, p.531-3, 1991.

BRASIL. Ministério da Saúde. Comissão Nacional de Normas e Padrões para Alimentos. Resolução $\mathrm{n}^{\mathrm{O}}$ 12/78 do Decreto Lei $\mathrm{n}^{\mathrm{o}}$ 55.871/65. In: ASSOCIAÇÃO BRASILEIRA DAS INDÚSTRIAS DE ALIMENTOS. Compêndio da Legislação de Alimentos. Rev. 7. São Paulo: ABIA, 1991. v.1A. p.7.4. 
BRUNNERT, H.; ZADRAZIL, F. The translocation of mercury and cadmium into the fruiting bodies of six higher fungi. European Journal of Applied Microbiology and Biotechnology, v.17, $\mathrm{n}^{\mathrm{o}}$ 6, p.358-64, 1983.

CANTARELLI, P.R. Processamento térmico de brotos de feijão (Vina radiata [L] Wilczek) acidificados. Piracicaba, 1992. 168p. Tese (livre-docência) - Escola Superior de Agricultura "Luiz de Queiroz", Universidade de São Paulo.

CANTARELLI, P.R.; NOGUEIRA, J.N.; GALLO, C.R.; VERTONI, P.C. Effect of acidification and fermentation on the quality characteristics of canned mung bean (Vigna radiata Wilczik) Sprouts. Acta Alimentaria, v.25, no 2, p.143-150, 1996.

CARUSO, J.G.B.; CAMARGO, R. Microbiologia de alimentos. Generalidades. Alteração dos alimentos. In: CAMARGO, R. de. Tecnologia dos produtos agropecuários - Alimentos. São Paulo: Nobel, 1984. p.35-49.

CARVALHO, P.R.N. Enriquecimento de alimentos: o uso de vitaminas e sais minerais para aumentar o valor nutritivo dos alimentos. Engarrafador Moderno, v.6, nº 39, p.54-59, maio/jun. 1995.

CATALÁ, R. Envases para alimentos. In: YÚFERA, E.P. Química agrícola III Alimentos. Madrid: Alhambra, 1980. p.607-673.

CEAGESP. Boletim Mensal Capital. São Paulo, 1980-1994.

CEAGESP/CACEX. Boletim Anual Capital. São Paulo, 1994-96. 
CHANG, S.T.; LAU, O.W.;'CHO, K.Y. The cultivation and nutritional value of Pleurotus sajor-caju. European Journal of Applied Microbiology and Biotechnology, v.12, p.58-62, 1981.

CHITARRA, M.I.F.; CHITARRA, A.B. Pós-colheita de frutos e hortaliças: fisiologia e manuseio. Lavras: laepe, 1990. 293p.

CORLETT, Jr. D.; DENNY, C.B. Canned foods - Tests for cause of spoilage. In: SPECK, M.L. Compendium of methods for the microbial examination of foods. Washington: American Public Health Association - APAH, 1984. p.737-777.

CRISAN, E.V.; SANDS, A. Nutritional value. In: CHANG, S.T.; HAYES, W.A. The biology and cultivation of edible mushrooms. New York: Academic Press, 1978. p.137-68.

DAWSON, R.H. Sensory texting guide for panel evaluation of food and beverages. Food Technology, v.8, nº 18, p.25-31, 1964.

DESPHANDE, A.G.; TAMHANE, D.V. Studies on dehydration of mushrooms (Volvariella volvacea). Journal of Food Science and Technology, v.18, $\mathrm{n}^{\mathrm{o}}$ 3, p.96-101, 1981.

EIRA, A.F.; MINHONI, M.T.A. Manual de Cultivo do "Hiratake" e "Shimeji" (Pleurotus spp.). Botucatu: UNESP/FEPAP, 1997. 63p. 
EVAngelista, J. Tecnologia de alimentos. Rio de Janeiro: Atheneu, 1987. $652 \mathrm{p}$.

FANG, T.T.; FOOTRAKUL, D.V. Studies on dehydration of mushrooms (Agaricus bisporus). Journal of Food Science and Technology, v. 18, $\mathbf{n}^{\circ} 3$, p.96-101, 1971.

FENJIN, H.E.; PURCELL, C.C.; HESS, W.M. Effects of calcium, sucrose and aging on the texture of canned great northern beans (Phaseolus vulgaris L.). Journal of Food Science, v.54, nº 1, p.315-318, 1989.

FERNANDES, M.H.C. Vida de prateleira de enlatados de origem vegetal. Boletim do Instituto de Tecnologia de Alimentos, v.19, $\mathrm{n}^{\mathbf{0}}$ 3, p.227-52, jul/set 1982 .

FERREIRA, V.L.P. Colorimetria em alimentos. Campinas: Instituto de Tecnologia de Alimentos, 1991. 43p.

FIGUEIREDO, M.B.; MUCCI, E.S.F. Doenças e pragas do cogumelo comestível. Biológico, v.51, n⿳ำ 4, p.93-111, 1995.

FLEGG, P.B.; SPENCER, D.M.; WOOD, D. The biology and technology of the cultived mushroom. Dorchester: John Wiley \& Sons Ltda, 1985, 345p.

FLEMING, H.P.; McFEETERS, R.F. Use of microbial cultures vegetable products. Food Technology, v.35, nº 1, p.84, 1981. 
FONSECA, H.; NOGUEIRA, J.N. Processamento e conservação de alimentos de origem vegetal - frutas. In: CAMARGO, R. et al. Tecnologia dos produtos agropecuários. Alimentos. São Paulo: Nobel, 1989. cap.7, p.113-124.

FOOD AND DRUG ADMINISTRATION. Pickled, fermented, acidified and lowacid foods. Federal Register, v.43, p. 30441-461, 1976.

FPI. Canned foods - Principles of thermal process control; acidification and container evaluation. Washington: The Food Processors Institute, 1982.

GAVA, A.J. Controvérsia sobre aditivos em alimentos. Alimentos e Tecnologia, v.13, p.28-30, jan./fev. 1987.

GAVA, A.J. Princípios de tecnologia de alimentos. São Paulo: Nobel, 1978. $284 p$.

GILL, W.J.; NICHOLAS, R.C.; MARKAKIS, P. Irradiation of cultured mushrooms. Food Technology, v.23, p.385-388, 1969.

GIRARDOT, N.F.; PERYAM, D.R.; SHARPIRO, L. Selection of sensory testing panels. Food Technology, v.4, nº 6, p.140-143, 1952.

GOMES, F.P. Curso de estatística experimental. São Paulo: Nobel, 1990. p.96125.

HEALT, H.B. Source book of flavows. Westport: AVI, 1981. p.269-271. 
HEIL, J.R.; McCARTHY, M.J. Influence of acidification on texture of canned carrots. Journal of Food Science, v.54, nº 4, p. 1092-1094, 1989.

JORGE, N. Curvas de secagem de cogumelo (Agaricus bisporus) e avaliação sensorial do produto após diferentes períodos de armazenagem. Viçosa, 1989. 80p. Tese (Mestrado) - Faculdade de Engenharia Agrícola, Universidade Federal de Viçosa.

KOMANOWSKY, M.; TALLEY, F.B.; ESKEW, R.K. Air drying of cultivated mushrooms. Food Technology, v.23, p.1020-1024, 1970.

KOSUP, P.; SISTRUNK, W.A. Quality attributes of fermented and acidified green beans. Journal of Food Science, v.47, p.1001-1005, 1982.

KOTZEKIDOU, P.; ROUKAS, T. Quality characteristics of fermented and acidified canned okra. Lebernsmittel Wissenchaft un Technologic, v.20, p.300-304, 1987.

KURASAWA, S.I.; SUGAHARA, T.; HAYASHI, J. Studies on dietary fibre of mushrooms and edible wild plants. Nutrition Reports Internacional, v.26, $\mathrm{n}^{\mathrm{o}} 2$, p.167-73, aug/1982.

LAU, O. Methods of chemical analysis of musrooms. In: CHANG, S.T.; QUIMIO, T.H. Tropical mushrooms: biological nature and cultivation methods. Hong Kong: The Chinese University Press, 1982, p.87-116. 
LEONARD, S.J.; MERSON, R.L.; MARSH, G.L.; HEIL, J.R. Estimating thermal degradation in processing of foods. Journal of Agricultural and Food Chemistry, v.4, p.392, 1982.

LUH, B.S.; KEAN, C.E. Canning of vegetables. In: LUH, B.S.; WOODROOF, J.G. Comercial vegetable processing. Westport: AVI, 1975, p.241-243.

LUH, B.S.; SOMOGYI, L.P.; MEEHAN, J.J. Vegetable dehydration. In: LUH, B.S.; WOODROOF, J.G. Commercial vegetable processing. Westport: AVI, 1975, p.395-396.

MARTIN, S.L. Selection and training of sensory judges. Food Technology, v.11, $\mathrm{n}^{\mathrm{o}} 27, \mathrm{p} .22-26,1973$.

MARTIN, Z. de; SGARBIERI, V.C.; MENEZES, T.B.; LEITÃO, M.G.; GARRUTI, R.S. Produção de purê de banana acidificado e néctar de banana. Coletânea do Instituto de Tecnologia de Alimentos, v.1, p.273-298, 1965/66.

MARTINEZ-CARRERA, D. Past and future of edible mushroom cultivation in Tropical America. Mushroom Science, v.12, nº 1, p.795-805, 1989.

MARTINEZ-CARRERA, D.; SOBAL, M.; MORALES, P.; LARQUESAAVEDRA, A. Propects of edible mushroom cultivation in developing countries. Food Laboratory News, v.8, nº 3, p.21-33, 1992. 
MATÉRIAS-primas e aditivos para fabricação de bebidas. Engarrafador Moderno, v.5, nº 36, p.20-21, nov./dez. 1994.

MATSUURA, F.C.A.U.; NOGUEIRA, J.N.; NEVES, E.M. Estudo sobre a viabilidade econômica para a instalação de uma agroindústria de processamento de cenoura acidificada. V Congresso de Iniciação Científica - Anais, Piracicaba, SP, 1990.

MAZIERO, R. Substratos alternativos para o cultivo de Pleurotus spp. São Paulo, 1990. 136p. Tese (Mestrado) - Instituto de Biociências, Universidade de São Paulo.

MCCORD, J.D.; KILARA, A. Control of enzymatic browning in processed mushrooms (Agaricus bisporus). Journal of Food Science, v.48, $\mathrm{n}^{\mathrm{o}} 5$, p.1479-1483, 1983.

MEURER, P.; GIERSCHENER, K. Occurence and effect of indigenous and eventual microbial enzymes in lactic acid fermented vegetables. Acta Alimentaria, v.21, p.171-188, 1992.

MOLENA, O. O moderno cultivo de cogumelos. São Paulo: Nobel, 1986. 170p.

MORAES, M.A.C. Métodos para avaliação sensorial dos alimentos. Campinas: Editora da Unicamp, 1985. 85p. 
MORI, K.; TOYOMASUT, T.; NANBA, H.; KURODA, H. Antitumor action of fruit bodies of edible mushrooms orally administred to mice. Mushroom Science, v.12, $\mathrm{n}^{\mathrm{o}}$ 1, p.653-60, 1987.

MUCHOVEJ, J.J.; MUCHOVEJ, R.M.C. Noções básicas de micologia. Viçosa: Universidade Federal de Viçosa, 1989. 155p.

NAZÁriO, G. Aditivos: pior sem eles. Alimentos e Tecnologia. v.3, no 18, p.3132, fev./mar. 1988.

NEW, W. Air-dried mushrooms. Agricultural Research, v.19, nº 7, p.6-39, 1971.

NICHOLS, R. Post-harvest physiology and storage. In: FLEGG, P.B.; SPENCER, D.M.; WOOD, D. The biology and technology of the cultived mushroom. Dorchester: John Wiley \& Sons Ltda, 1985, 345p.

NICHOLS, R.; HAMMOND, J.B.W. The relationship between respiration, atmosphere and quality in intact and perforated mushroom prepacks. Journal of Food Tecnology, v. 10, p.427-435, 1975.

NOGUEIRA, J.N. Estudo sobre o processamento do palmito (Euterpe edulis Mart.) por apertização. Piracicaba, 1979. 141p. Tese (Livre-docência) Escola Superior de Agricultura "Luiz de Queiroz", Universidade de São Paulo. 
NOGUEIRA, J.N. Otimização da acidificação de hortaliças via fermantação e adição direta de ácidos para processamento térmico. Piracicaba, 1991. 25p. Proposta de Projeto - Fundação de Estudos Agrários "Luiz de Queiroz", Universidade de São Paulo.

NOGUEIRA, J.N.; CANTARELLI, P.R.; GALLO, C.R.; MATSUURA, Y. Effect of calcium addition, acidification and fermentation on the quality characteristics of canned carrots (Daucus carota L.). Acta Alimentaria, v.23, nº 2, p.147-155, 1994.

NOGUEIRA, J.N.; CANTARELLI, P.R:; GALLO, C.R.; MORENO, I.A.M.; MARTUSUURA, Y.; TIBA, M.A. Effect of calcium addition and acidification on the quality characteristics of canned okra (Hibiscus esculentus L.) Sciencia Agricola, v.50, nº 1, p.127-139, 1993.

PASCHOALINO, J.E. Congelamento de hortaliças. In: PASCHOALINO, J.E. Processamento de hortaliças. Campinas: ITAL, 1989. p.48-49.

PAVANELLO, J.F. O uso de aditivos em alimentos. Alimentos e Bebidas, v. 1, $\mathrm{n}^{\mathrm{o}}$ 7, p.22-24, mar. 1990.

POWERS, J.J.; MORSE, R.E.; SANE, R.H.; MILLS, W.C. Acidification and calcium - firming of canned pimuntos. Food Technology, v.4, p.485, 1960.

PUZZI, D. Armazenamento e abastecimento de grãos. Campinas: Instituto Campineiro de Ensino Agrícola, 1986. 603p. 
QUAST, D.G.; BERNHARDT, L.W. Curvas de titulação do palmito de cinco espécies de palmeiras. Coletânea do Instituto Tecnológico de Alimentos, v.7, $\mathrm{n}^{\mathrm{o}} 2$, p.241-264, 1976.

RAJARATHNAM, S.; BANO, Z. Pleurotus mushrooms. Part IA. Morfology, life cicle, toxonomy, breeding and cultivation. Critical Reviews in Food Science and Nutrition, v.26, $\mathrm{n}^{\mathrm{0}}$ 2, p. 157-223, 1987.

RAJARATHNAM, S.; BANO, Z. Pleurotus mushrooms. Part III. Biotransformations of natural lignocellulosic wastes: commercial applications and implications. Critical Reviews in Food Science and Nutrition, v.28, $\mathrm{n}^{\mathrm{o}}$ 1, p.31-113, 1989.

SALDANA, G.; MEYER, R. Effects of added calcium on texture and quality of canned jalapeno peppers. Journal of Food Science, v.46, no ${ }^{\circ}$, p.1518-1520, 1981.

SHIROSE, I. Estatística aplicada à experimentação organoléptica. Campinas: Instituto de Tecnologia de Alimentos, 1985. p.96-111.

STURION, G.L. Utilização da folha da bananeira como substrato para o cultivo de cogumelos comestíveis (Pleurotus spp.). Piracicaba, 1994. 147p. Tese (Mestrado) - Escola Superior de Agricultura "Luiz de Queiroz", Universidade de São Paulo. 
STURION, G.L.; RANZANI, M.R.T. de. Produção do cogumelo comestivel Pleurotus: opção promissora, especialmente na região do Vale do Ribeira. Série Produtor Rural, no 2, 48p., 1997.

SUCOS de frutas - um mercado em desenvolvimento. Alimentos e Bebidas, v.1, $\mathrm{n}^{\mathrm{o}}$ 5, p. 48-50, ago./set. 1989 .

TADA, T.S.; IKEDA, S.; KUWAJINA, T. Cultivo de cogumelos comestíveis. Campinas: Boletim Técnico 210 da CATI, 1992. 19p.

TOLEDO, M.C. de F. Considerações sobre avaliação toxicológica de aditivos para alimentos. Alimentos e Tecnologia, v.2, nº 12, p.62-63, nov./dez. 1986.

TRESSLER, D.K.; JOSLYN, M.A. Fruits and vegetable juice processing technology. Chicago: AVI. Westport, 1961. 1028p.

TRUFEM, S.F.B.; BONOMI, V.L.R. Cogumelos comestíveis. São Paulo: Ícone, 1985. 83p.

VAN BUREN, J.P. Adding calcium to snap beans at different stages in processing: calcium yptake and texture of the canned product. Food Tecnology, v.22, nº 6, p.790-793, 1968.

VAN BUREN, J.P. The chemistry of texture in fruits and vegetables. Journal of Texture Studies, v.10, $\mathrm{n}^{\mathrm{o}}$ 1, p.1-23, 1979. 
VOLPI, L. Aditivos alimentares. Alimentação e Nutrição, v.6, nº 23, p.40-44, set. 1985 .

WOOD, D.A.; SMITH, J.F. The cultivation of mushrooms. In: NORRIS, J.R.; PETTIPHER, G.L. Essays in agricultural and food microbiology. New York: John Wiley \& Sons, 1987. p.309-43.

ZADRAZIL, F. Influence of ammonium nitrate and organic suplements on the yield of Pleurotus sajor-caju (Fr.) Sing. European Journal of Applied Microbiology and Biotechnology, v.9, p.31-35, 1980.

ZADRAZIL, F.; GRABBE, K. Edible mushrooms. Biotechnology, v.3, p.145-87. 1983.

ZAPATA, M.M.; QUAST, D.G. Curvas de titulação do palmito doce (Eutherpe edulis Mart.). Coletânea do Instituto de Tecnologia de Alimentos, v.6, p.167-187, 1975.

ZHUANG, C.; MIZUNO, T.; SHIMADA, A.; ITO, H.; SUZUKI, C.; MAYUZUMI, Y.; OKAMOTO, H.; MA, Y.; LI, J. Antitumor protein containing polysaccharies from a chinese mushroom Fengweigu or Houbitake, Pleurotus sajor-caju (Fr.). Sings. Bioscience, Biotechnology and Biochemistry, v.57, $\mathrm{n}^{\circ}$ 6, p.901-6, 1993. 